\title{
Annual Report-1994 Environmental Surveillance for Waste Management Facilities at the Idaho National Engineering Laboratory
}

Kelly C. Wright

Roger N. Wilhelmsen

Bryan W. Borsella

Maria Miles

Published August 1995

Idaho National Engineering Laboratory

Lockheed Martin Idaho Technologies

Idaho Falls, Idaho 83415

Prepared for the

U.S. Department of Energy

Assistant Secretary for

Environmental Management

Under DOE Idaho Operations Office

Contract DE-AC07-94ID13223 


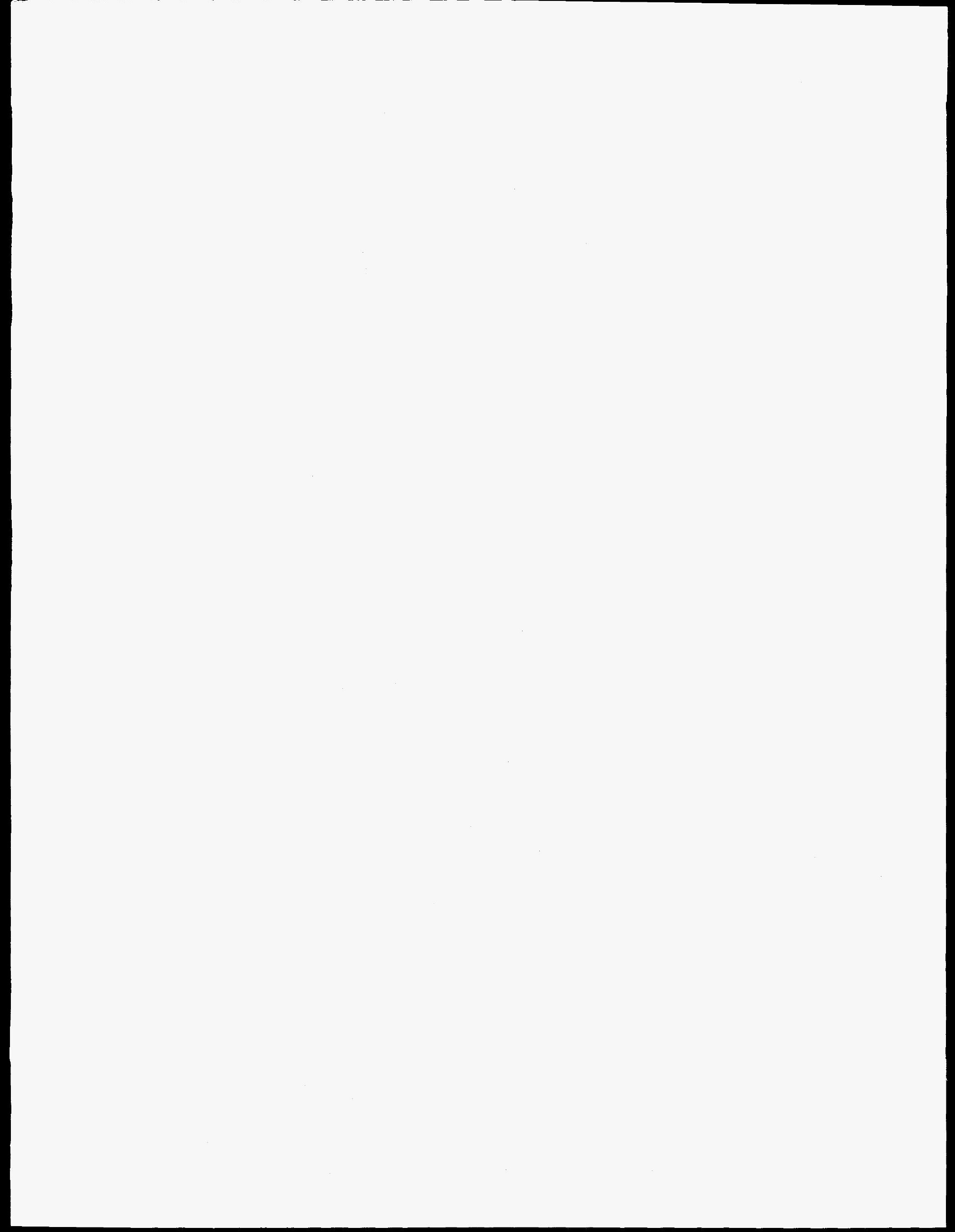




\begin{abstract}
This report describes calendar year 1994 environmental surveillance activities of Environmental Monitoring of Lockheed Martin Idaho Technologies, performed at Waste Management Facilities at the Idaho National Engineering Laboratory (INEL). The major facilities monitored include the Radioactive Waste Management Complex, the Waste Experimental Reduction Facility, the Mixed Waste Storage Facility, and two surplus facilities. Included are results of the sampling performed by the Radiological Environmental Surveillance Program, INEL Environmental Surveillance Program, and the United States Geological Survey. The primary purposes of monitoring are to evaluate environmental conditions, to provide and interpret data, to ensure compliance with applicable regulations or standards, and to ensure protection of human health and the environment. This report compares 1994 environmental surveillance data with U.S. Department of Energy derived concentration guides and with data from previous years.
\end{abstract}

\title{
DISCLAIMER
}

This report was prepared as an account of work sponsored by an agency of the United States Government. Neither the United States Government nor any agency thereof, nor any of their employees, makes any warranty, express or implied, or assumes any legal liability or responsibility for the accuracy, completeness, or usefulness of any information, apparatus, product, or process disclosed, or represents that its use would not infringe privately owned rights. Reference herein to any specific commercial product, process, or service by trade name, trademark, manufacturer, or otherwise does not necessarily constitute or imply its endorsement, recommendation, or favoring by the United States Government or any agency thereof. The views and opinions of authors expressed herein do not necessarily state or reflect those of the United States Government or any agency thereof. 



\section{DISCLAIMER}

Portions of this document may be illegible in electronic image products. Images are produced from the best available original document. 


\section{SUMMARY}

This report describes the environmental surveillance performed in calendar year 1994 by the Radiological Environmental Surveillance Program (RESP). The Environmental Monitoring Program of Lockheed Martin Idaho Technologies established the RESP to perform surveillance at Waste Management Facilities at the Department of Energy (DOE) Idaho National Engineering Laboratory (INEL), including the Radioactive Waste Management Complex (RWMC), the Waste Experimental Reduction Facility (WERF), and the Mixed Waste Storage Facility (MWSF). RESP also conducts surveillance at two contaminated surplus facilities: the Stationary LowPower Reactor No. 1 (SL-1) and the Organic-Moderated Reactor Experiment (OMRE). Results are presented for the 1994 air, water, soil, biotic, and ambient radiation monitoring activities performed. In addition, this report discusses current methods and monitoring programs of RESP, along with groundwater monitoring at RWMC by the United States Geological Survey (USGS).

In 1994, the concentrations of gross beta activity in airborne particulate material at the RWMC, WERF, and MWSF were below DOE derived concentration guides (DCGs) for airborne release to a public area. Gamma spectrometric analyses did not identify any gamma-emitting radionuclides above background in airborne particulates at the RWMC, WERF, or MWSF.

There were no statistically significant differences between concentrations of gross beta activity in airborne particulates at the RWMC and those measured at the control location (Experimental Breeder Reactor No. 1), and the concentrations were consistent with historical values. All air samples collected during 1994 were submitted for alpha- and beta-emitting radionuclide analysis. Airborne $\mathrm{Sr}-\mathbf{9 0}$ was detected in the second quarter at $0.003 \%$ of the DCG for airborne releases to the public. Airborne Am-241 was detected in the third quarter at $0.04 \%$ of the DCG in air. No airborne alpha- or beta-emitting radionuclides were detected during the first and fourth quarters.

Surface water run-off samples were collected from the RWMC during the first and second quarters of 1994. During the first quarter, a sample collected at TSA-1 of the Transuranic Storage Area (TSA) contained Cs-137, which was the only gamma-emitting radionuclide detected in any of the RWMC surface water run-off samples. The concentration for this radionuclide was $0.03 \%$ of the appropriate DCG. Am-241 was detected at the TSA-2 location. This concentration represented $0.12 \%$ of the DCG in water. $\mathrm{Pu}-239,-240$ was also detected at the TSA-2 location. This concentration represented $0.37 \%$ of the DCG in water. Beginning in the fourth quarter of 1994, surface run-off water was collected from WERF seepage basins. No gammaemitting radionuclides were detected in any of the samples collected.

During 1994, soil samples were collected from the five major areas at the RWMC. Cs-137 was the only gamma-emitting radionuclide detected in the RWMC soil samples. These concentrations are comparable to historical samples and are within the range of concentrations attributed to fallout. Selected soil samples were submitted for alpha- and beta-emitting radionuclide analyses. $\mathrm{Sr}-90, \mathrm{Pu}-239,-240$, and $\mathrm{Am}-241$ were detected on all the major areas at the RWMC.

During 1994, biota and excavated soil samples were scheduled for collection. However, the recontouring effort at the RWMC greatly reduced the availability of biota. As a result, no biotic samples were collected because it was unlikely that a representative sample could be obtained.

Around the current waste disposal pit and at localized areas within the SDA, thermoluminescent dosimeter (TLD) data showed exposures above background exposures and exposures that were higher than those previously registered. This observation is probably a result of the storage of higher level waste in the active disposal pit and 
the waste movement from the IntermediateLevel Transuranic Storage Facility to the Certified and Segregated Waste Storage building during the second quarter reporting period of 1994. The maximum six-month ionizing radiation exposure measured by TLDs at the RWMC have, in general, decreased over time since 1974, with the exception of the active disposal pit.

Analysis of the WERF TLD data from November 1982 to November 1994 shows that the sixmonth exposures measured immediately around the WERF waste storage area were higher than all other exposures measured at WERF. This difference is due to the proximity of the TLD monitoring location to the radioactive waste storage area at WERF.

Surface radiation was routinely monitored at RWMC and at both surplus facilities, SL-1, and OMRE. No areas at the RWMC showed a reading

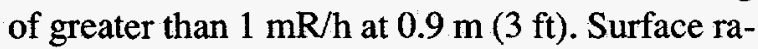
diation surveys showed increases in the radiation levels during 1994. No areas with levels exceeding the SL-1 administrative control limit $(20 \mathrm{mR} / \mathrm{h}$ gamma/beta at contact were identified at SL-1. No areas at the OMRE exceeded the administrative control limit ( $1 \mathrm{mR} / \mathrm{h}$ gamma at contact).

The USGS wells at the RWMC are monitored regularly for selected volatile organic compounds, specific conductance, chloride, and sodium. No maximum contaminant levels were exceeded for volatile organic compounds or radiological analyses. No positive detections of gamma-emitting radionuclides occurred in any of the wells.

Tritium was detected in three of nine RWMC wells monitored by the USGS, with a maximum concentration of $0.1 \%$ of the DCG. This tritium is attributed to past disposals from waste water operations at the Idaho Chemical Processing Plant and the Test Reactor Area. The concentrations detected in 1994 were similar to results reported in previous years. 


\section{ACKNOWLEDGMENTS}

The authors wish to thank all of the people who contributed to the preparation of this report: Matthew R. Hankins, Curtiss Peterson, Steve Peterson, and Linda Hodges for assisting in sample collection and preparation; Teresa Meachum for contributing to the statistical sections of this report; the Radiation Measurements Laboratory and the Radiation and Environmental Measurement Systems, especially Don Koeppen, Cal Rowsell, Tom C. Sorensen, and Steven Hartenstein, for providing analyses and results; the United States Geological Survey, especially Brennon Orr, for providing the data on groundwater monitoring; Fred Bickford, Paul Ritter, and Leah Street for reviewing this report; Gwenna Hill for editing this report; and Kathy Killpack for preparing the document. 


\section{CONTENTS}

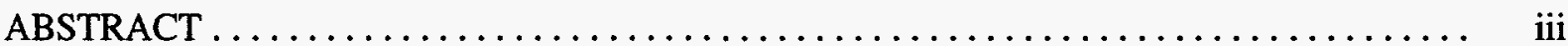

SUMMARY $\ldots \ldots \ldots \ldots \ldots \ldots \ldots \ldots \ldots \ldots \ldots \ldots \ldots \ldots \ldots \ldots \ldots \ldots \ldots \ldots \ldots$

ACKNOWLEDGMENTS $\ldots \ldots \ldots \ldots \ldots \ldots \ldots \ldots \ldots \ldots \ldots \ldots \ldots \ldots \ldots \ldots \ldots \ldots \ldots$ vii

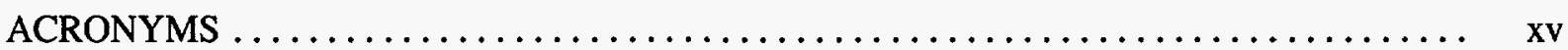

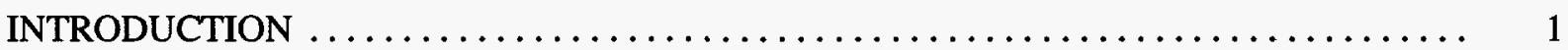

Overview of Monitoring Activities $\ldots \ldots \ldots \ldots \ldots \ldots \ldots \ldots \ldots \ldots \ldots \ldots \ldots \ldots \ldots$

Radiological Environmental Surveillance of Waste Management Facilities ....... 3

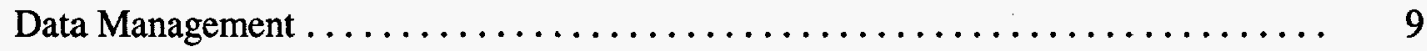

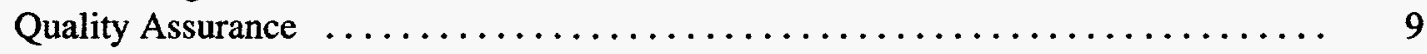

Monitoring Activities Review $\ldots \ldots \ldots \ldots \ldots \ldots \ldots \ldots \ldots \ldots \ldots \ldots \ldots$

Description of Waste Management Facilities $\ldots \ldots \ldots \ldots \ldots \ldots \ldots \ldots \ldots \ldots \ldots$

Radioactive Waste Management Complex .................... 10

Waste Experimental Reduction Facility . . . . . . . . . . . . . . . . . . 12

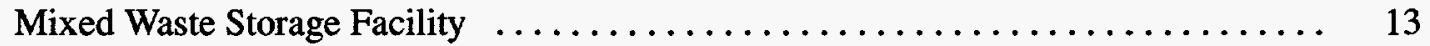

Stationary Low-Power No. 1 Surplus Area $\ldots \ldots \ldots \ldots \ldots \ldots \ldots \ldots \ldots \ldots \ldots \ldots \ldots$

Organic-Moderated Reactor Experiment ...................... 14

MONITORING METHODS AND RESULTS $\ldots \ldots \ldots \ldots \ldots \ldots \ldots \ldots \ldots \ldots \ldots \ldots$

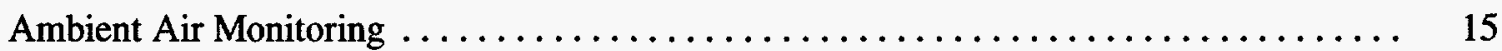

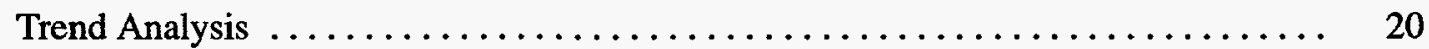

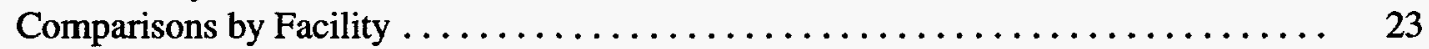

Radioactive Waste Management Complex ...................... 26

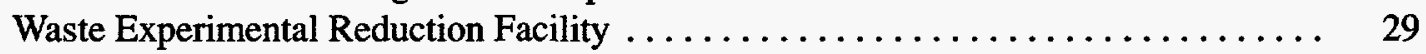

Mixed Waste Storage Facility $\ldots \ldots \ldots \ldots \ldots \ldots \ldots \ldots \ldots \ldots \ldots \ldots \ldots \ldots \ldots \ldots$

Surface Water Run-off $\ldots \ldots \ldots \ldots \ldots \ldots \ldots \ldots \ldots \ldots \ldots \ldots \ldots \ldots \ldots \ldots \ldots \ldots \ldots \ldots$

Radioactive Waste Management Complex $\ldots \ldots \ldots \ldots \ldots \ldots \ldots \ldots \ldots \ldots \ldots . \ldots \ldots \ldots$

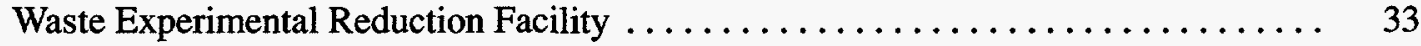

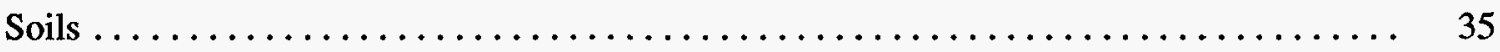

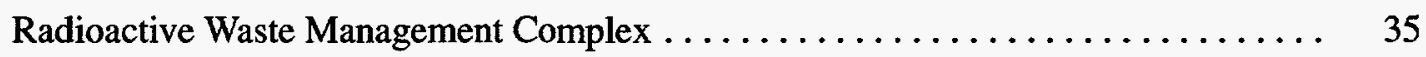

Waste Experimental Reduction Facility $\ldots \ldots \ldots \ldots \ldots \ldots \ldots \ldots \ldots \ldots \ldots . . \ldots \ldots$

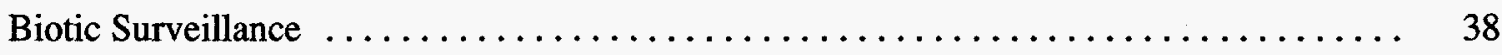

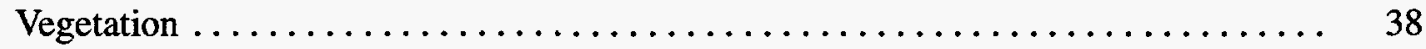

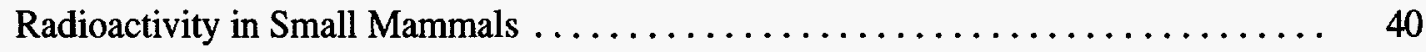


Soil Excavated by Small Mammals $\ldots \ldots \ldots \ldots \ldots \ldots \ldots \ldots \ldots \ldots \ldots \ldots$

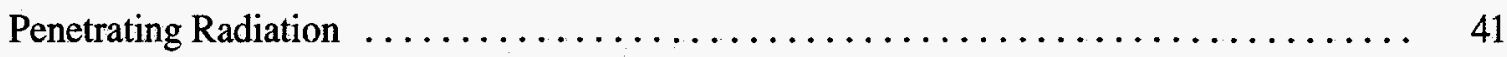

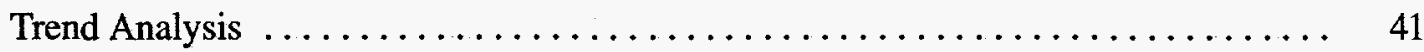

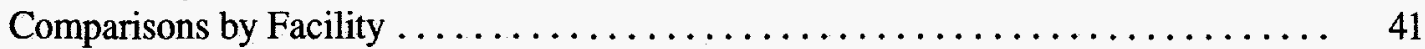

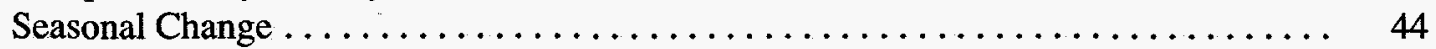

Radioactive Waste Management Complex ....................... 44

Waste Experimental Reduction Facility $\ldots \ldots \ldots \ldots \ldots \ldots \ldots \ldots \ldots \ldots \ldots \ldots \ldots \ldots \ldots$

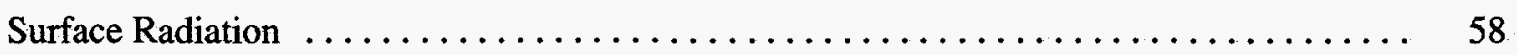

Radioactive Waste Management Complex ................... 58

Stationary Low-Power Reactor No. $1 \ldots \ldots \ldots \ldots \ldots \ldots \ldots \ldots \ldots \ldots \ldots \ldots$

Organic-Moderated Reactor Experiment $\ldots \ldots \ldots \ldots \ldots \ldots \ldots \ldots \ldots \ldots \ldots .58$

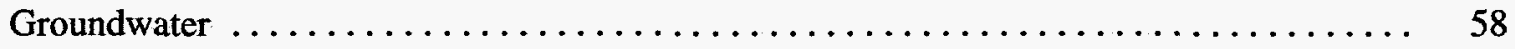

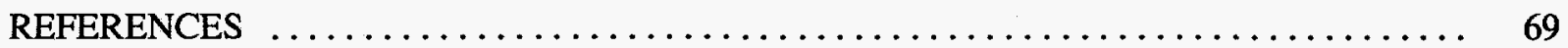

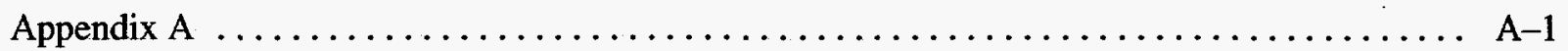

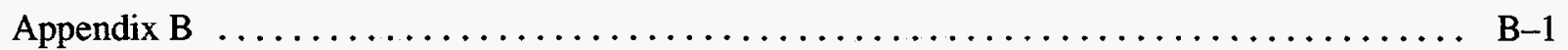

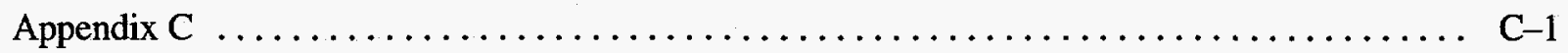

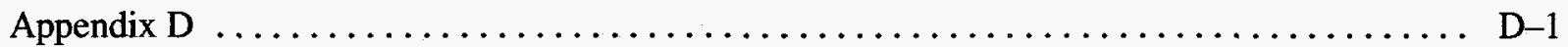

\section{FIGURES}

1. Idaho National Engineering Laboratory location map $\ldots \ldots \ldots \ldots \ldots \ldots \ldots \ldots$

2. Map of the Radioactive Waste Management Complex $\ldots \ldots \ldots \ldots \ldots \ldots \ldots \ldots \ldots \ldots$

3. Aerial photograph of the Radioactive Waste Management Complex (facing west) $\ldots \ldots \ldots \quad 11$

4. Aerial photograph of the Stored Waste Examination Pilot Plant (facing south) $\ldots \ldots \ldots .12$

5. Aerial photograph of the Waste Experimental Reduction Facility (facing east) $\ldots \ldots \ldots 13$

6. Collection of particulate air filter from $\mathrm{LV}$ air monitor $\ldots \ldots \ldots \ldots \ldots \ldots \ldots \ldots \ldots$

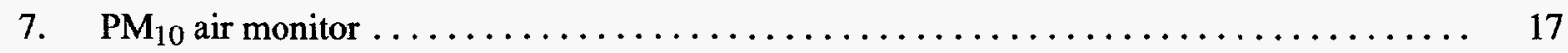

8. Collection of particulate air filter from a $\mathrm{PM}_{10}$ air monitor $\ldots \ldots \ldots \ldots \ldots \ldots \ldots \ldots$

9. RWMC SP and $\mathrm{PM}_{10}$ air monitoring locations $\ldots \ldots \ldots \ldots \ldots \ldots \ldots \ldots \ldots \ldots \ldots$

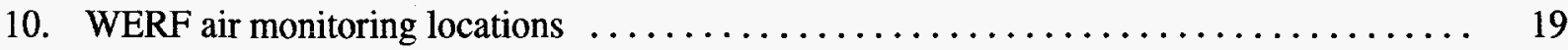

11. WERF air monitoring control location at the Main Guard Gate $\ldots \ldots \ldots \ldots \ldots \ldots \ldots \ldots$ 
12. 1994 gross alpha concentrations for $\mathrm{PM}_{10}$ air monitors using second order polynomial

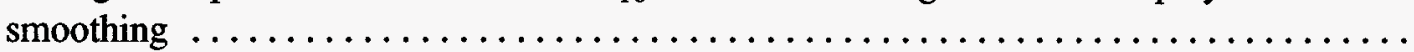

13. 1994 gross alpha concentrations for SP air monitors using second order polynomial smoothing

14. 1994 gross beta concentrations for $\mathrm{PM}_{10}$ air monitors using second order polynomial smoothing

15. 1994 gross beta concentrations for SP air monitors using second order polynomial smoothing

16. Gross alpha concentrations by monitor type for Locations $2,15,20,26$, and 300 using third order polynomial smoothing

17. Gross beta concentrations by monitor type for Locations $2,15,20,26$, and 300 using third order polynomial smoothing

18. 1993 and 1994 Box and Whisker plots of the gross alpha concentrations by facility and monitor type

19. 1993 and 1994 Box and Whisker plots of the gross beta concentrations by facility and

20. Quarterly averages of RWMC gross beta air concentrations since 1983

21. Gross beta concentration (Cs-137 equivalent) trends for SDA air filters during each semimonthly period of 1994

22. Gross beta concentration (Cs-137 equivalent) trends for SWEPP air filters during each semimonthly period of 1994

23. SESP monthly average gross beta concentrations (LV air monitors)

24. Am-241 and Pu-239,-240 quarterly composite concentrations for air filters at RWMC locations

25. Quarterly average of gross beta air concentrations measured at WERF

26. Maximum gross beta concentrations (Cs-137 equivalent) for WERF air filters during each semimonthly period of 1994

27. Maximum gross beta concentrations (Cs-137 equivalent) for MWSF air filters during each semimonthly period of 1994

28. RWMC surface water run-off collection

29. Sampling locations for surface water run-off

30. WERF surface water run-off sampling locations

31. Soil sample collection 
32. Five major areas of the RWMC used for vegetation, mammal, and soil collection ...... 36

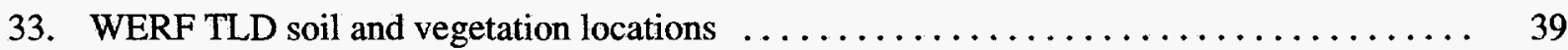

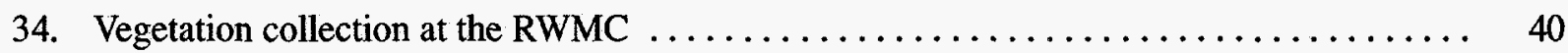

35. Placement of a TLD at a facility perimeter station $\ldots \ldots \ldots \ldots \ldots \ldots \ldots \ldots \ldots \ldots \ldots$

36. TLD exposure data from SDA, TSA, and WERF using negative exponential smoothing . . $\quad 42$

37. 1993 Box and Whisker plots of the TLD exposure by facility $\ldots \ldots \ldots \ldots \ldots \ldots \ldots$

38. 1994 Box and Whisker plots of the TLD exposure by facility $\ldots \ldots \ldots \ldots \ldots \ldots \ldots$

39. Exposure trends for the spring and fall average TLD measurements $\ldots \ldots \ldots \ldots \ldots$

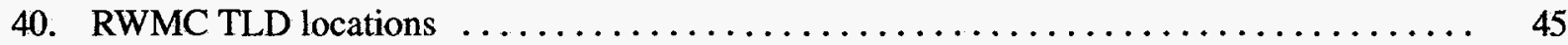

41. Six-month exposures measured by TLDs on the northwest border of the SDA $\ldots \ldots \ldots \quad 46$

42. Six-month exposures measured by TLDs on the northeast border of the SDA $\ldots \ldots \ldots$

43. Six-month exposures measured by TLDs on the south border of the SDA $\ldots \ldots \ldots \ldots .47$

44. Six-month exposures measured by TLDs on the southwest border of the SDA $\ldots \ldots \ldots 47$

45. Six-month exposures measured by TLDs on the southeast border of the SDA $\ldots \ldots \ldots$

46. Six-month exposures measured by TLDs on the west border of the SDA $\ldots \ldots \ldots \ldots$

47. Six-month exposures measured by two of the four TLDs on the east border of the SDA near

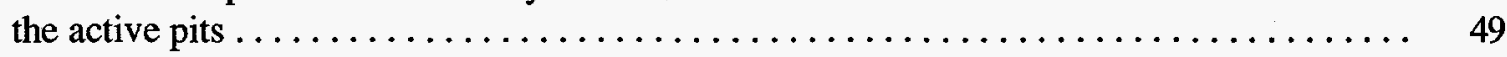

48. Six-month exposures measured by two of the four TLDs on the east border of the SDA near

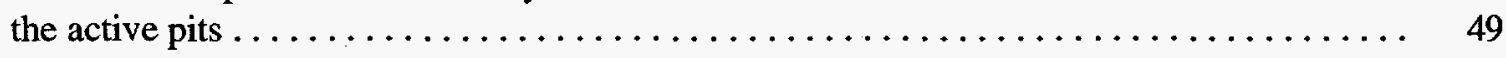

49. Six-month exposures measured by TLDs on the north border of the TSA $\ldots \ldots \ldots \ldots 2$

50. Six-month exposures measured by two of the four TLDs on the south and southeast borders

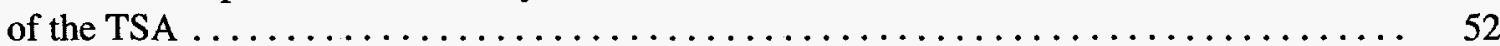

51. Six-month exposures measured by TLDs on the south border of the TSA $\ldots \ldots \ldots \ldots$

52. Six-month exposures measured by TLDs on the east and northeast borders of the TSA $\ldots \quad 53$

53. Six-month exposures measured by TLDs north of TSA $\ldots \ldots \ldots \ldots \ldots \ldots \ldots \ldots \ldots$

54. Six-month exposures measured by TLDs located $500 \mathrm{~m}$ and $400 \mathrm{~m}$ northeast of WERF ... 54

55. Six-month exposures measured by TLDs located $300 \mathrm{~m}$ and $200 \mathrm{~m}$ northeast of WERF ... 55

56. Six-month exposures measured by TLDs located northeast and southeast of the $50-\mathrm{m}$

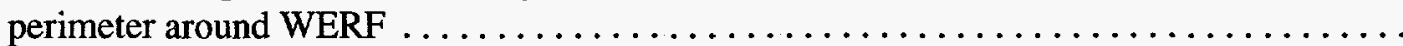


57. Six-month exposures measured by TLDs located southwest and northwest of the 50-m

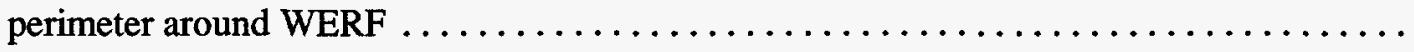

58. Six-month exposures measured by TLDs located northwest, southwest, and southeast of the perimeter around WERF

59. VRM-1 and HHD -440 meter radiation detector system $\ldots \ldots \ldots \ldots \ldots \ldots \ldots \ldots \ldots$

60. Results of 1994 spring and fall RWMC surface radiation surveys $\ldots \ldots \ldots \ldots \ldots \ldots \ldots$

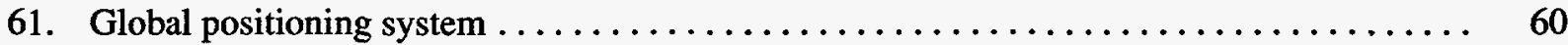

62. OMRE surface gamma radiation survey area and areas exceeding background levels $\ldots \ldots \quad 61$

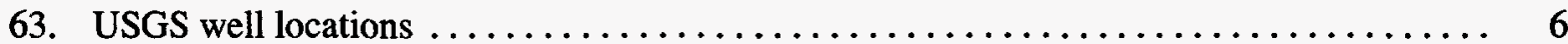

\section{TABLES}

1. Radiological Environmental Surveillance Program activities performed at Waste Management Facilities

2. Summary statistics for gross alpha concentrations (all concentration values are $\mathrm{E}-15 \mu \mathrm{Ci} / \mathrm{cc})$

3. Summary statistics for gross beta concentrations (all concentration values are $\mathrm{E}-15 \mu \mathrm{Ci} / \mathrm{cc})$

4. Specific radionuclide results for RWMC soils

5. Summary statistics for 1994 TLD 6-month exposures (all concentration values are $\mathrm{mR}$ ) ..

6. Results of chemical analyses of subsurface water at the RWMC in 1994

7. Concentrations $(\mu \mathrm{g} / \mathrm{L})$ of selected volatile organic compounds in groundwater

8. Results of radiochemical analyses of RWMC subsurface water .

B-1. RESP samples for radiochemical analysis

B-2. RESP air, water, and soil samples for gamma spectrometry

B-4

B-3. RESP biotic samples for gamma spectrometry .

B-4. Description of RESP samples for gamma spectrometry analysis B-6

D-1. Derived concentration guides B-8

D-2. Environmental concentration guidelines for common radionuclides found in environmental soil samples collected at the RWMC

D-3. Standards for volatile organic compounds D-7

D-4. Applicable radiological drinking water standards D-8 


\section{ACRONYMS}

\begin{tabular}{|c|c|c|c|}
\hline ANL-W & Argonne National Laboratory-West & NRF & Naval Reactor Facility \\
\hline ARA & Auxiliary Reactor Area & NRTS & National Reactor Testing Station \\
\hline $\mathrm{C} \& S$ & $\begin{array}{l}\text { Certified and Segregated Waste } \\
\text { Storage }\end{array}$ & OMRE & $\begin{array}{l}\text { Organic-Moderated Reactor } \\
\text { Experiment }\end{array}$ \\
\hline CFA & Central Facilities Area & & \\
\hline $\begin{array}{l}\text { CFR } \\
\mathrm{CV}\end{array}$ & $\begin{array}{l}\text { Code of Federal Regulations } \\
\text { coefficient of variation }\end{array}$ & $\begin{array}{l}\text { PBF } \\
\mathrm{PM}_{10}\end{array}$ & $\begin{array}{l}\text { Power Burst Facility } \\
\text { particulate matter } \leq 10 \mu \mathrm{m}\end{array}$ \\
\hline $\begin{array}{l}\text { DCG } \\
\text { DOE }\end{array}$ & $\begin{array}{l}\text { derived concentration guide } \\
\text { U.S. Department of Energy }\end{array}$ & QA & quality assurance \\
\hline DOE-ID & $\begin{array}{l}\text { U.S. Department of Energy } \\
\text { Idaho Operations Office }\end{array}$ & RESL & $\begin{array}{l}\text { Radiological and Environmental } \\
\text { Sciences Laboratory }\end{array}$ \\
\hline DQO & data quality objectives & RESP & $\begin{array}{l}\text { Radiological Environmental } \\
\text { Surveillance Program }\end{array}$ \\
\hline EBK-1 & $\begin{array}{l}\text { Experimental Breeder Reactor } \\
\text { No. I } \\
\text { effective dose equivalent }\end{array}$ & $\begin{array}{l}\text { RML } \\
\text { RWMC }\end{array}$ & $\begin{array}{l}\text { Radiation Measurements Laboratory } \\
\text { Radioactive Waste Management }\end{array}$ \\
\hline $\begin{array}{l}\text { EDE } \\
\text { EFS }\end{array}$ & $\begin{array}{l}\text { effective dose equivalent } \\
\text { Experimental Field Station }\end{array}$ & & Complex \\
\hline EMIS & $\begin{array}{l}\text { Environmental Monitoring } \\
\text { Information System }\end{array}$ & $\begin{array}{l}\text { SDA } \\
\text { SESP }\end{array}$ & $\begin{array}{l}\text { Subsurface Disposal Area } \\
\text { Site Environmental Surveillance }\end{array}$ \\
\hline ESP & $\begin{array}{l}\text { Environmental Surveillance } \\
\text { Program }\end{array}$ & SESF & $\begin{array}{l}\text { Site Environmental Surveillance } \\
\text { Program }\end{array}$ \\
\hline ESRF & $\begin{array}{l}\text { Environmental Science and } \\
\text { Research Foundation }\end{array}$ & $\mathrm{SL}-1$ & $\begin{array}{l}\text { Stationary Low-Power Reactor } \\
\text { No. } 1\end{array}$ \\
\hline ESRP & Eastern Snake River Plain & $\begin{array}{l}\text { SP } \\
\text { SPERT }\end{array}$ & $\begin{array}{l}\text { suspended particulate } \\
\text { Special Power Excursion Reactor }\end{array}$ \\
\hline FAAT & $\begin{array}{l}\text { Federal Aviation Administration } \\
\text { Tower }\end{array}$ & $\begin{array}{l}\text { SRPA } \\
\text { SWEPP }\end{array}$ & $\begin{array}{l}\text { Test } \\
\text { Snake River Plain Aquifer } \\
\text { Stored Waste Examination Pilot }\end{array}$ \\
\hline GPRS & $\begin{array}{l}\text { global positioning radiometric } \\
\text { scanner }\end{array}$ & & Plant \\
\hline ICPP & Idaho Chemical Processing Plant & $\begin{array}{l}\text { TAN } \\
\text { TLD }\end{array}$ & $\begin{array}{l}\text { Test Area North } \\
\text { thermoluminescent dosimeter }\end{array}$ \\
\hline IDAPA & $\begin{array}{l}\text { Idaho Administrative Procedures } \\
\text { Act }\end{array}$ & TRA & $\begin{array}{l}\text { Test Reactor Area } \\
\text { transuranic }\end{array}$ \\
\hline ILTSF & $\begin{array}{l}\text { Intermediate-Level Transuranic } \\
\text { Storage Facility }\end{array}$ & TSA & Transuranic Storage Area \\
\hline INEL & $\begin{array}{l}\text { Idaho National Engineering } \\
\text { Laboratory }\end{array}$ & USGS & United States Geological Survey \\
\hline $\begin{array}{l}\text { LLW } \\
\text { LV }\end{array}$ & $\begin{array}{l}\text { low-level radioactive waste } \\
\text { low-volume }\end{array}$ & $\begin{array}{l}\text { VOC } \\
\text { VRM-1 }\end{array}$ & $\begin{array}{l}\text { volatile organic compound } \\
\text { vehicle--mounted roadway } \\
\text { monitor number one }\end{array}$ \\
\hline $\begin{array}{l}\text { MAR } \\
\text { MCL } \\
\text { MWSF }\end{array}$ & $\begin{array}{l}\text { Monitoring Activities Review } \\
\text { maximum contaminant level } \\
\text { Mixed Waste Storage Facility }\end{array}$ & WERF & $\begin{array}{l}\text { Waste Experimental Reduction } \\
\text { Facility } \\
\text { Waste Isolation Pilot Plant }\end{array}$ \\
\hline
\end{tabular}


xvi 


\section{Annual Report-1994 \\ Environmental Surveillance for Waste Management Facilities at the Idaho National Engineering Laboratory \\ INTRODUCTION}

In 1949, the National Reactor Testing Station (NRTS) was established in southeastern Idaho by the U.S. Atomic Energy Commission as an area to build, test, and operate nuclear reactors. The installation also included a fuel-processing plant and support facilities with maximum safety and isolation. In 1974, the NRTS was redesignated as the Idaho National Engineering Laboratory (INEL) to reflect a broader scope of engineering and scientific activities. The INEL is owned by the Department of Energy (DOE), and EG\&G Idaho, Inc., was the prime contractor until October 1, 1994, when Lockheed Martin Idaho Technologies was awarded the consolidated contract to manage the facility.

The INEL, located on the Eastern Snake River Plain (ESRP) in southeastern Idaho, encompasses an area approximately $2300 \mathrm{~km}^{2}$. Air masses entering the ESRP from any direction must first cross a mountain barrier, which results in precipitation of a large percentage of any moisture contained in the air masses before it reaches the region. Average precipitation is $22 \mathrm{~cm}$ with maximum levels occurring in winter and late spring. Thus, the region exhibits semiarid characteristics. The local northeast-southwest orientation of the ESRP and the bordering mountain ranges tend to channel the prevailing west winds so that a southwest wind (daytime) predominates over the INEL. The second-most frequent winds (nighttime) come from the northeast. The regions relatively dry air and infrequent low clouds permit intense solar heating of the surface during the day and rapid cooling at night. These factors combine to give a large diurnal range of temperatures near the ground. Because of the moderating influence of the Pacific Ocean, most of the air masses flowing over this area are usually warmer during winter and cooler in the summer than air masses flowing at a similar latitude in the more continental climate east of the Continental Divide. The Centennial and Bitterroot Mountain ranges keep most of the shallow, but intensely cold winter air masses from entering the ESRP when they move southward from Canada. Occasionally, however, cold air spills over the mountains. When this happens, the cold air is held in the ESRP by the surrounding mountains, and the INEL experiences low temperatures for periods lasting a week or longer. The annual average temperature is $5.6^{\circ} \mathrm{C}$, with recorded extremes of -43.9 and $39.4^{\circ} \mathrm{C} .{ }^{1}$

Subsurface geology at the INEL consists of successive layers of basalt and sedimentary strata, overlaid at the surface by wind- and water-deposited sediments. The primary groundwater source in the region is the Eastern Snake River Plain Aquifer (SRPA). Most of the INEL is located in the Mud Lake-Lost River Basin (Pioneer Basin), which is a closed drainage basin. Surface water within the Pioneer Basin includes that from the Big Lost River, the Little Lost River, and Birch Creek, all of which drain mountain watersheds located to the north and northwest of the INEL. Local rainfall and snowmelt contribute to surface water, mainly during the spring months. In high-flow years, the surface water can flow onto the site in any of the three surface water drainages (i.e., Birch Creek, Little Lost River, and Big Lost River). Birch Creek flows into the Birch Creek Playa on the north end of the INEL. The portion of the inflowing water that is not lost to evapotranspiration infiltrates into the subsurface. The Little Lost River flows onsite during high-flow years and a portion infiltrates into the subsurface. Both aquifer and surface waters are used for irrigation outside the 
INEL. The SRPA is used as a drinking water source both on and off the INEL.

INEL soils are derived from silicic volcanic and Paleozoic, sedimentary rocks from nearby mountains and buttes and are underlain by basalt. Therefore, basalt outcrops are common. Soils in the southern part of the INEL are gravelly to rocky and generally shallow. In general, INEL soils have formed as a result of alluvial or aeolian deposition over basaltic lava flows.

The INEL lies within an area designated as a sagebrush ecosystem. This broad ecosystem occupies vast plains and plateaus created from lava flows, ancient lake beds, and broad basins of alluvium. It is characterized by shrubs with an understory of perennial grasses and herbs. The flora in areas surrounding the waste management areas are typical of those found elsewhere on the INEL. ${ }^{2}$ The dominant and most conspicuous plant on the INEL is sagebrush, which covers approximately $80 \%$ of the area $\left(113,664 \mathrm{~km}^{2}\right)$. Crested wheatgrass seedings are also found throughout the INEL and have existed for 25 or more years, with little evidence of re-invasion by native species. Limited dispersal from the native community and abundant seed production by the crested wheatgrass perpetuate this community. Areas occupied by crested wheatgrass support a lower density of birds, mammals, and reptiles than do areas dominated by sagebrush. 3,4

Thirty-nine species of mammals are found on the INEL, 18 of which are rodents. The Townsend's ground squirrel, least chipmunk, Great Basin pocket mouse, Ord's kangaroo rat, and montane vole are the most common small mammals on the site. These rodents are relatively common throughout sagebrush regions of the Intermountain West. Game species such as sage grouse and antelope are frequently seen in these areas.

In 1994, the U.S. Department of Energy Idaho Operations Office (DOE-ID) divided the Radiological and Environmental Sciences Laboratory Environmental Surveillance Program (RESLESP) into two programs, offsite and onsite, and transferred the operation of the two parts to contractors. The offsite program and all ecological and radioecological research previously performed by the Environmental Sciences Branch of RESL was officially transferred to the Environmental Science and Research Foundation on April 5, 1994. On January 1, 1994, the onsite program [Site Environmental Surveillance Program (SESP)] was transferred to the EG\&G Idaho Environmental Monitoring Program as an interim measure until Lockheed Martin Idaho was awarded the contract to run the INEL on October 1,1994 . These two contractor-operated programs comprise the INEL-ESP. To ensure a smooth transition of the two portions of the RESL-ESP with minimal data discontinuities, the successor contractors (Environmental Science and Research Foundation and Lockheed Martin Idaho) continued sampling in the same manner and at the same locations as the RESLESP through the end of calendar year 1994.

The Radiological Environmental Surveillance Program (RESP) provides monitoring data for all INEL Waste Management Facilities. Routine monitoring was performed outside the Radioactive Waste Management Complex (RWMC) and around other operational facilities on the INEL site during 1994. The RESP activities are structured to support DOE-ID in maintaining an integrated INEL environmental monitoring program. The National Oceanic and Atmospheric Administration cooperates with DOE on a meteorology monitoring network. The United States Geological Survey (USGS) routinely monitors groundwater at the INEL, including wells in and adjacent to waste management areas.

RESP, conducted by the Environmental Monitoring and Water Resources Unit, has the following general objectives: (a) provide indications of confinement integrity at radioactive waste storage and disposal facilities, (b) ensure compliance with applicable requirements regarding environmental surveillance of radioactivity at DOE Waste Management facilities, (c) identify trends in concentrations of radioactivity in environmental media near INEL Waste Management Facilities, (d) make monitoring data available to other programs conducting activities such as perfor- 
mance assessment, pathways analysis, and dose estimation, and (e) collect data in support of special studies designed to enhance RESP technical capabilities.

These stated program objectives are to be interpreted as including the program objectives identified in DOE Order 5400.1, Chapter IV; and DOE Order 5820.2A, Chapter II; for environmental surveillance of DOE Waste Management facilities. 5,6

\section{Overview of Monitoring Activities}

\section{Radiological Environmental Surveillance of Waste Management Facilities}

A comprehensive radiological monitoring program is conducted at INEL Waste Management Facilities. This program includes routine and special studies of radioactive materials in air, water, soil, and biota (vegetation and small mammals) and ambient radiation monitoring (see Table 1).

The Waste Management Facilities monitored by RESP at the INEL (see Figure 1) include the RWMC, the Waste Experimental Reduction Facility (WERF), the Stored Waste Examination Pilot Plant (SWEPP), the Stationary Low-Power Reactor No. 1 (SL-1) surplus area, the OrganicModerated Reactor Experiment (OMRE) area, and the Mixed Waste Storage Facility (MWSF).

The RWMC is used to dispose of low-level radioactive waste (LLW) and to store transuranic (TRU) waste received from the INEL and other DOE sites. Other waste management activities normally conducted at the WERF, MWSF, and SWEPP include waste reduction and incineration, mixed waste storage, TRU waste certification and processing, research, and technology development.

Airborne transport is the most likely near-term pathway for radionuclide migration from the active RWMC and WERF facilities. Consequently, more extensive air monitoring is conducted at these facilities to detect airborne transport of radionuclides.

Surface water run-off sampling is conducted quarterly at the RWMC and WERF if sufficient water is available. The resulting samples are analyzed to determine radionuclide concentrations in run-off water and to determine if radionuclide transport from the area is possible during run-off conditions. Generally, run-off water does not flow from the RWMC except during rapid snowmelt or after heavy rainfalls.

RESP is responsible for routine soil monitoring at the RWMC and WERF. A preliminary assessment of surface soils was conducted at all EG\&G Idaho facilities during 1989. The SESP is responsible for conducting periodic soil monitoring outside the RWMC and WERF. The purposes of soil sampling and analysis are to determine whether RWMC and WERF operations contribute to soil contamination and to determine longterm trends. Surface soils that have not been recontoured at the RWMC demonstrate radionuclide levels slightly above background due to past transportation and handling of radioactive wastes, past flooding, or migration from buried waste. ${ }^{7}$ Surface soils at WERF could possibly become contaminated by deposition of radionuclides in airborne effluents or as a result of radioactive waste handling.

Biota can affect the integrity of buried contaminated waste by penetrating the soil and allowing water to reach the waste or by transporting radionuclides to the surface. Therefore, routine sampling of small mammals and vegetation is also conducted by RESP to detect potential biological radionuclide transport. Vegetation sampling is conducted annually at RWMC and WERF. Small mammal sampling and sampling of soil excavated by burrowing animals are conducted only at the RWMC. 
Table 1. Radiological Environmental Surveillance Program activities performed at Waste Management Facilities.

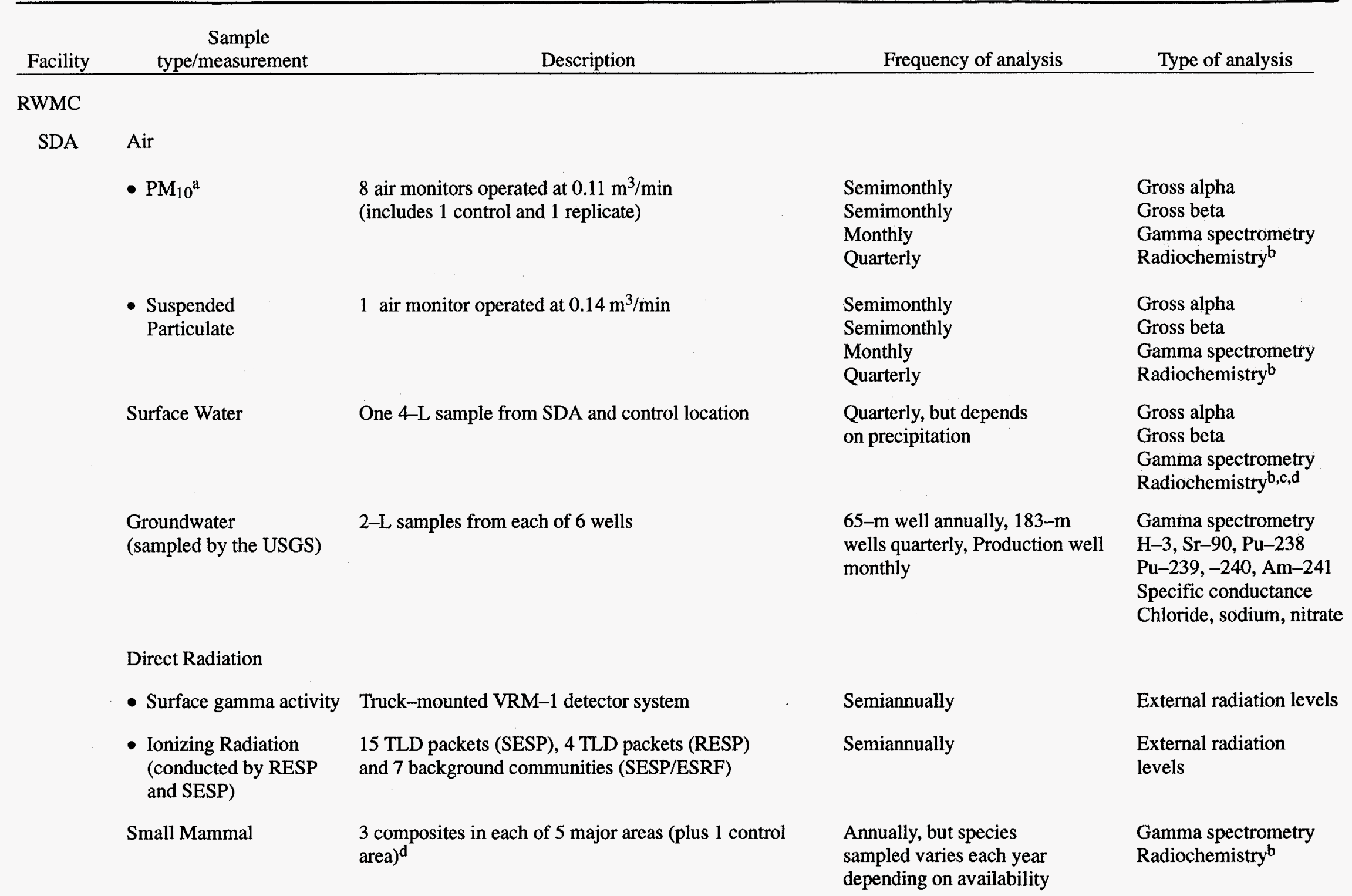


Table 1. (continued).

\begin{tabular}{|c|c|c|c|c|}
\hline Facility & $\begin{array}{c}\text { Sample } \\
\text { type/measurement }\end{array}$ & Description & Frequency of analysis & Type of analysis \\
\hline & Soil & $\begin{array}{l}5 \text { surface locations in each of } 5 \text { major areas } \\
\text { (plus } 1 \text { control area) }\end{array}$ & Triennially & $\begin{array}{l}\text { Gamma spectrometry } \\
\text { Radiochemistry }\end{array}$ \\
\hline & Vegetation & $\begin{array}{l}3 \text { composites in each of } 5 \text { major areas (plus } 1 \text { control } \\
\text { area) }\end{array}$ & $\begin{array}{l}\text { Annually, but species } \\
\text { sampled varies each } \\
\text { year as determined by availability }\end{array}$ & $\begin{array}{l}\text { Gamma spectrometry } \\
\text { Radiochemistry }^{b}\end{array}$ \\
\hline & Visual Inspection & Tour SDA and TSA & Monthly & $\begin{array}{l}\text { Results reported for any } \\
\text { required corrective action }\end{array}$ \\
\hline \multirow[t]{8}{*}{ SWEPP } & Air & & & \\
\hline & - $\mathrm{PM}_{10} \mathrm{a}^{\mathrm{a}}$ & 5 air monitors operated at $0.11 \mathrm{~m}^{3} / \mathrm{min}$ & $\begin{array}{l}\text { Semimonthly } \\
\text { Semimonthly } \\
\text { Monthly } \\
\text { Quarterly }\end{array}$ & $\begin{array}{l}\text { Gross alpha } \\
\text { Gross beta } \\
\text { Gamma spectrometry } \\
\text { Radiochemistryb }\end{array}$ \\
\hline & $\begin{array}{l}\text { - Suspended } \\
\text { Particulate }\end{array}$ & 2 air monitors operated at $0.14 \mathrm{~m}^{3} / \mathrm{min}$ & $\begin{array}{l}\text { Semimonthly } \\
\text { Semimonthly } \\
\text { Monthly } \\
\text { Quarterly }\end{array}$ & $\begin{array}{l}\text { Gross alpha } \\
\text { Gross beta } \\
\text { Gamma spectrometry } \\
\text { Radiochemistry } b\end{array}$ \\
\hline & Surface Water & $\begin{array}{l}\text { One 4-L sample from TSA-1, TSA-2, TSA-3, } \\
\text { TSA-4, and control locations }\end{array}$ & $\begin{array}{l}\text { Quarterly, but depends } \\
\text { on precipitation }\end{array}$ & $\begin{array}{l}\text { Gross alpha } \\
\text { Gross beta } \\
\text { Gamma spectrometry } \\
\text { Radiochemistryb }\end{array}$ \\
\hline & Soil & 9 locations sampled (plus 2 control areas) & Triennially & $\begin{array}{l}\text { Gamma spectrometry } \\
\text { Radiochemistry }\end{array}$ \\
\hline & \multicolumn{4}{|l|}{ Direct Radiation } \\
\hline & $\begin{array}{l}\text { - Surface gamma } \\
\text { activity }\end{array}$ & Truck-mounted VRM-1 detector system & Semiannually & External radiation levels \\
\hline & $\begin{array}{l}\text { Ionizing radiation } \\
\text { (conducted by RESP } \\
\text { and SESP) }\end{array}$ & $\begin{array}{l}9 \text { TLD packets (SESP), } 3 \text { TLD packets (RESP) } \\
\text { and } 7 \text { background communities (SESP/ESRF) }\end{array}$ & Semiannually & $\begin{array}{l}\text { External radiation } \\
\text { levels }\end{array}$ \\
\hline
\end{tabular}


Table 1. (continued).

\begin{tabular}{|c|c|c|c|c|}
\hline Facility & $\begin{array}{c}\text { Sample } \\
\text { type/measurement }\end{array}$ & Description & Frequency of analysis & Type of analysis \\
\hline \multirow[t]{7}{*}{ WERF } & Air & & & \\
\hline & - $\mathrm{PM}_{10} \mathrm{a}$ & $\begin{array}{l}3 \text { air monitors operated at } 0.11 \mathrm{~m} / 3 / \mathrm{min} \\
\text { (includes } 1 \text { control) }\end{array}$ & $\begin{array}{l}\text { Semimonthly } \\
\text { Semimonthly } \\
\text { Monthly }\end{array}$ & $\begin{array}{l}\text { Gross alpha } \\
\text { Gross beta } \\
\text { Gamma spectrometry }\end{array}$ \\
\hline & $\begin{array}{l}\text { - Suspended } \\
\text { Particulate }\end{array}$ & 1 air monitor operated at $0.14 \mathrm{~m}^{3} / \mathrm{min}$ & $\begin{array}{l}\text { Semimonthly } \\
\text { Semimonthly } \\
\text { Monthly }\end{array}$ & $\begin{array}{l}\text { Gross alpha } \\
\text { Gross beta } \\
\text { Gamma spectrometry }\end{array}$ \\
\hline & Direct Radiation & & & \\
\hline & $\begin{array}{l}\text { - Ionizing radiation } \\
\text { conducted by RESP } \\
\text { and SESP }\end{array}$ & $\begin{array}{l}11 \text { TLD packets (RESP) and } 7 \text { background } \\
\text { communities (SESP/ESRF) }\end{array}$ & Semiannually & $\begin{array}{l}\text { External radiation } \\
\text { levels }\end{array}$ \\
\hline & $\begin{array}{l}\text { Soil } \\
\text { - Surface Soils } \\
\text { - Seepage Basins }\end{array}$ & $\begin{array}{l}15 \text { surface locations } \\
3 \text { locations }\end{array}$ & $\begin{array}{l}\text { Trienniallye } \\
\text { Annually }\end{array}$ & $\begin{array}{l}\text { Gamma spectrometrye } \\
\text { Gamma spectrometry }\end{array}$ \\
\hline & Vegetation & 15 locations (includes 3 controls) & Triennially & Gamma spectrometry \\
\hline \multirow[t]{2}{*}{ MWSF } & Air & & & \\
\hline & - $\mathrm{PM}_{10} \mathrm{a}$ & 1 air monitor operated at $0.11 \mathrm{~m}^{3} / \mathrm{min}$ & $\begin{array}{l}\text { Semimonthly } \\
\text { Semimonthly } \\
\text { Monthly }\end{array}$ & $\begin{array}{l}\text { Gross alpha } \\
\text { Gross beta } \\
\text { Gamma spectrometry }\end{array}$ \\
\hline \multirow[t]{3}{*}{ SL-1 } & Direct Radiation & & & \\
\hline & $\begin{array}{l}\text { - Surface gamma } \\
\text { activity }\end{array}$ & Hand-hèld HHD-440 & Semiannually & $\begin{array}{l}\text { External radiation } \\
\text { levels }\end{array}$ \\
\hline & Visual Inspection & Tour SL-1 & Semiannually & $\begin{array}{l}\text { Results reported for any } \\
\text { required corrective action }\end{array}$ \\
\hline
\end{tabular}


Table 1. (continued).

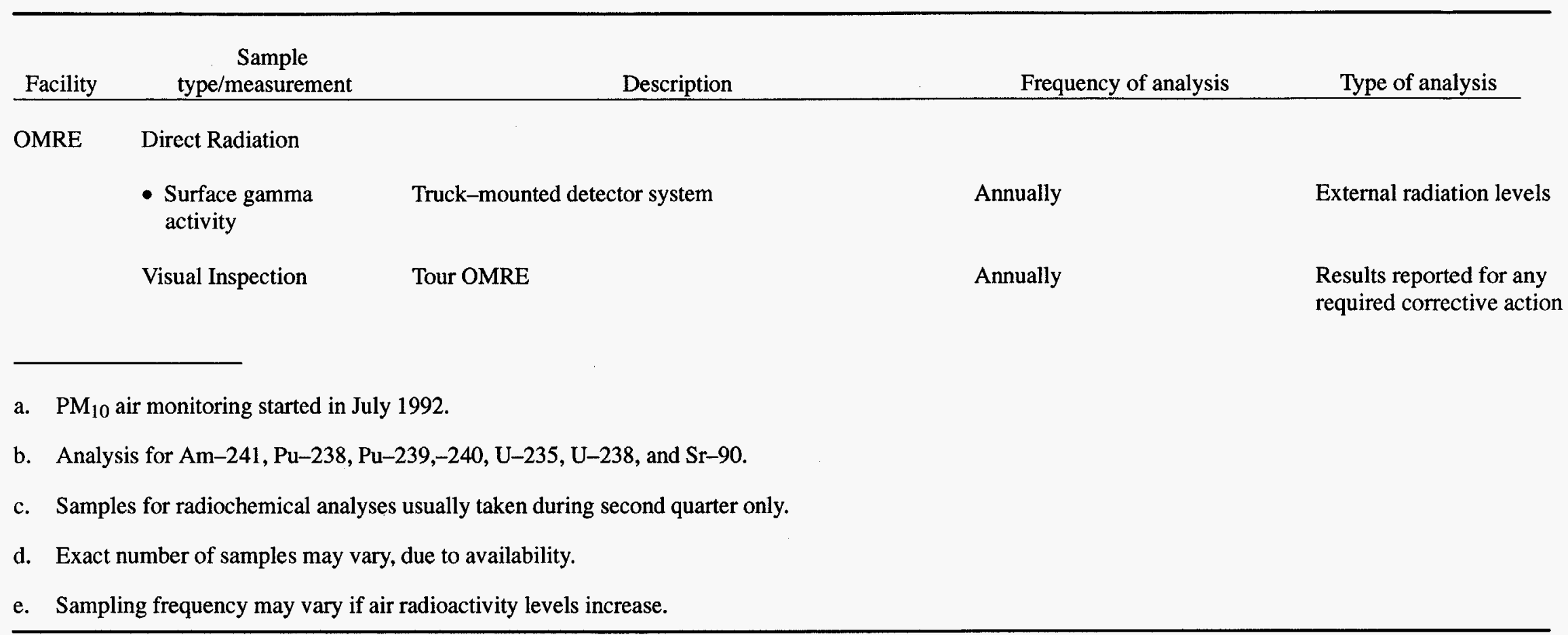




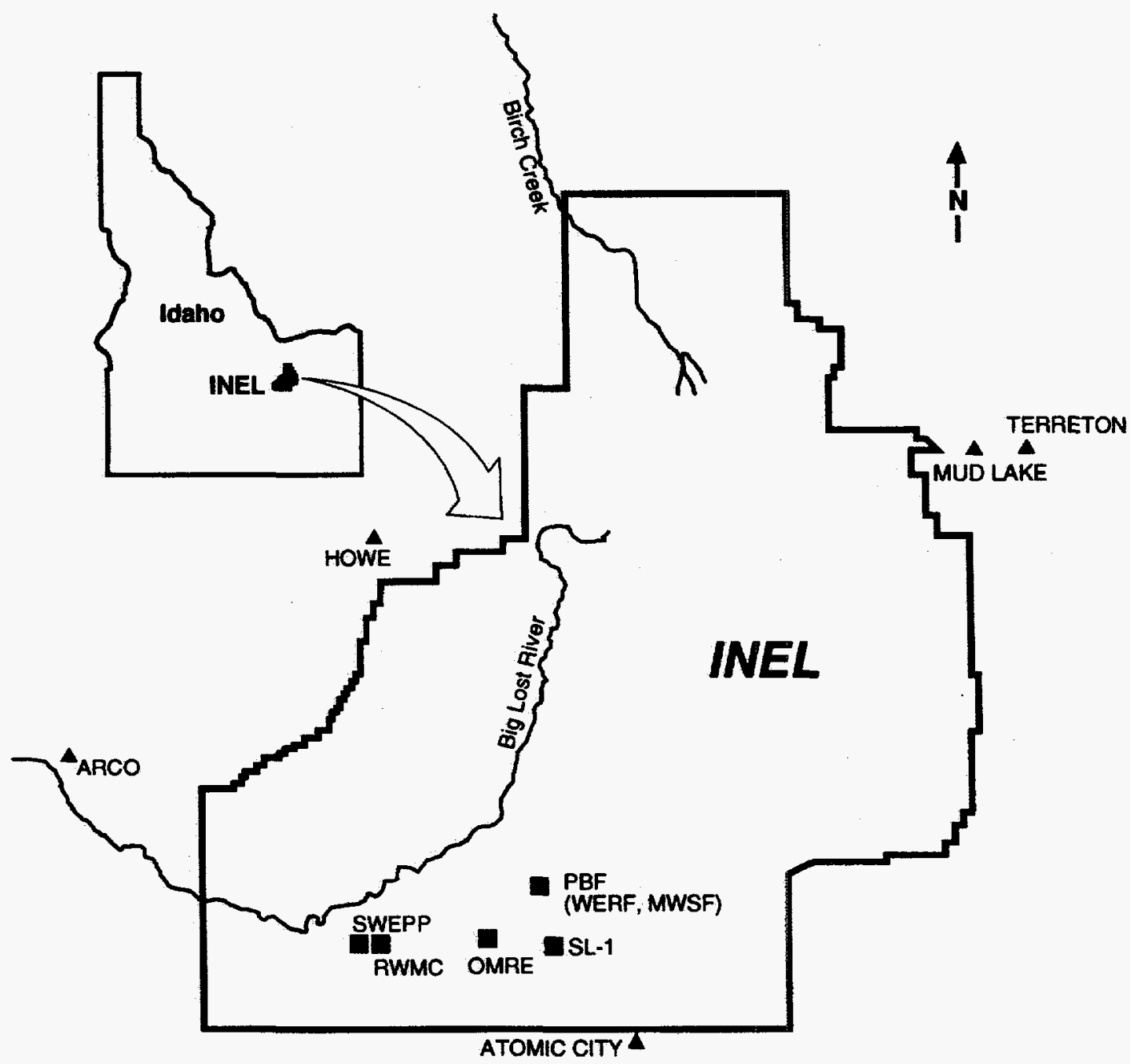

Selected Facilities at the Idaho National Engineering Laboratory

MWSF Mixed Waste Storage Facility

OMRE Organic Moderated Reactor Experiment (inactive)

PBF Power Burst Facility
RWMC Radioactive Waste Management Complex

SL-1 Stationary Low Power Reactor No.1 Burial Ground

SWEPP Stored Waste Examination Pilot Plant

WERF Waste Experimental Reduction Facility
A Towns

a Facilities

INEL Boundary

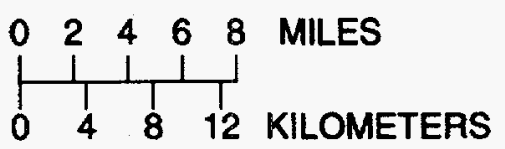

8930158

Figure 1. Idaho National Engineering Laboratory location map. 
Thermoluminescent dosimeters (TLDs) are used to measure cumulative exposures to ambient ionizing radiation at the RWMC and WERF. The TLDs are used to detect changes in ambient exposures attributable to handling, processing, or disposing of radioactive waste. In addition, a surface radiation survey is conducted at the RWMC every six months to monitor all areas within the facility boundary.

The SL -1 surplus area, located near the SL -1 reactor site, contains buried radioactively contaminated building remnants in one pit and two trenches. The OMRE area includes a leach pond and an area formerly occupied by a reactor facility, which has been decontaminated and decommissioned. The SL-1 and OMRE are nonoperational surplus facilities, and both require less surveillance than the RWMC, WERF, and MWSF. Table 1 summarizes the monitoring activities conducted at the RWMC, WERF, MWSF, SL-1, and OMRE during 1994.

The INEL Project Office of the USGS monitors SRPA groundwater, which is approximately $177 \mathrm{~m}$ beneath the RWMC. This monitoring helps determine whether radionuclides and hazardous constituents have migrated from the waste to the groundwater. Water samples are collected quarterly from eight aquifer wells and one perched-water well located in and adjacent to the RWMC Subsurface Disposal Area (SDA). These samples are analyzed for radiological and nonradiological parameters.

\section{Data Management}

The Environmental Monitoring Information System (EMIS) has been developed for radiological monitoring activities at the INEL. The purposes of the EMIS data management system are to maintain program-specific databases (i.e., effluent, SESP, RESP, drinking water, etc.), store and sort data, provide a method of tracking trends in monitoring data, and help generate various monitoring reports.

\section{Quality Assurance}

The Quality Assurance (QA) Program is integrated into all of the measurement programs described above. The QA Program has been developed to ensure that the sampling methods provide representative samples, to confirm that laboratory analyses are reliable, and to verify that the quality of reported results is adequate. Sampling and analysis protocols have been documented in detailed procedures for collecting, analyzing, and reporting of results. A description of the QA Program is found in the Quality Program Plan for Environmental Monitoring. ${ }^{8}$ Detailed QA information on the RESP, such as data quality objectives and QA objectives, can be found in the Radiological Environmental Surveillance Program Plan for Waste Management Facilities. ${ }^{9}$ (See Appendix A for QA objectives.)

\section{Monitoring Activities Review}

Changes in the existing program are made as a result of periodic Monitoring Activities Reviews (MARs). The MAR process involves a technical review by a group of technical experts from the INEL and outside the INEL. The program is reviewed against current regulatory requirements and guidance, recent innovations in methods and equipment, data trends, and data deficiencies. One consideration in the MAR process is the desire to maintain continuity with past designs for trending purposes. Other considerations include logistics, cost of implementation, compatibility with ongoing operations, and jurisdictional constraints. Based on the comments of the reviewers, the monitoring program or activity design is revised, or recommended special studies are conducted to further investigate the need for revision. The most recent MAR was completed in March $1992,{ }^{10}$ and the next MAR is scheduled for the summer of 1995. 


\section{Description of Waste Management Facilities}

\section{Radioactive Waste Management Complex}

The RWMC occupies $59 \mathrm{~km}^{2}$ of the southwestern part of the INEL (see Figures 2 and 3 ) in the north-central portion of the ESRP. The facility is situated in a small valley surrounded by basaltic ridges rising to $18 \mathrm{~m}$ above the landscape. Surface sediments vary in thickness from 0 to $7 \mathrm{~m}$ and consist of unconsolidated clay, silt, and gravel. The elevation is $1527 \mathrm{~m}$ above sea level.

RWMC consists of three major areas: the SDA, $39 \mathrm{~km}^{2}$; the Transuranic Storage Area (TSA), $23 \mathrm{~km}^{2}$; and the Administrative and Operational Facility area, $7 \mathrm{~km}^{2}$. Low-level waste is segregated at the SDA according to the level of radioactivity and container size, and then placed in a large pit (Pit 17) or in soil vaults (boreholes). Each filled pit or soil vault is covered with a minimum of $1 \mathrm{~m}$ of soil. Wastes contaminated with TRU elements in concentrations greater than $100 \mathrm{nCi} / \mathrm{g}$ are stored at the TSA in $208-\mathrm{L}$ steel drums, fiber-glass-covered wooden boxes, or steel bins.

Pad A, formerly called the Transuranic Disposal Area, is a prominent waste management area within the SDA. Pad A was originally an asphalt-surfaced area established to store uranium waste, primarily in the form of nitrate salts. The waste contains enriched and depleted uranium. Some waste containing TRU elements was also placed on Pad A from 1972 to 1978. Most of the TRU waste measures less than $10 \mathrm{nCi} / \mathrm{g}$. However, a number of TRU waste drums are known to measure between 10 and $100 \mathrm{nCi} / \mathrm{g}$, and a very small percentage of drums measure greater than $100 \mathrm{nCi} / \mathrm{g}$. Waste containing beryllium is also stored on Pad A. When the pad was filled with stacked waste drums and boxes, the containers were covered with a 1-m layer of soil. Pad A was closed in November 1978.
Two facilities located in the TSA, the SWEPP building (see Figure 4) and the Certified and Segregated Waste Storage (C\&S) building, are used to examine stored TRU waste to ensure it meets the waste acceptance criteria of the Waste Isolation Pilot Plant (WIPP) located in New Mexico. Waste is retrieved, examined, and segregated into certifiable and uncertifiable waste packages. The certifiable waste packages will be prepared for shipment to WIPP. The C\&S building (TSA-3) is an air-supported storage building located on a $43 \times 254-\mathrm{m}$ asphalt pad. The pad slopes from the center to the outer edges and from south to north. Drainage ditches on either side of the pad drain into sump pits.

The C\&S building is currently active for surface storage of waste contaminated with TRU elements in concentrations greater than $100 \mathrm{nCi} / \mathrm{g}$. In the past, waste containers were stacked on asphalt pads similar to Pad A and covered with plywood, plastic, and soil when pad areas were filled. Now, drums of TRU waste are stored in TSA-3 on an asphalt pad and enclosed in an air-supported weather shield. Boxes of TRU waste, covered with vinyl-coated nylon, are also stored outside on TSA R because retrieval of the waste is planned. Nine buildings are being constructed to allow retrieval and Resource Conservation and Recovery Act-approved storage of all waste currently stored on the SDA.

Transuranic waste with high radiation levels (greater than $200 \mathrm{mR} / \mathrm{h}$ at contact) requiring remote handling is stored at the IntermediateLevel Transuranic Storage Facility (ILTSF) within the TSA. Such waste is stored in subsurface, cylindrical metal vaults capped with removable shield plugs. 


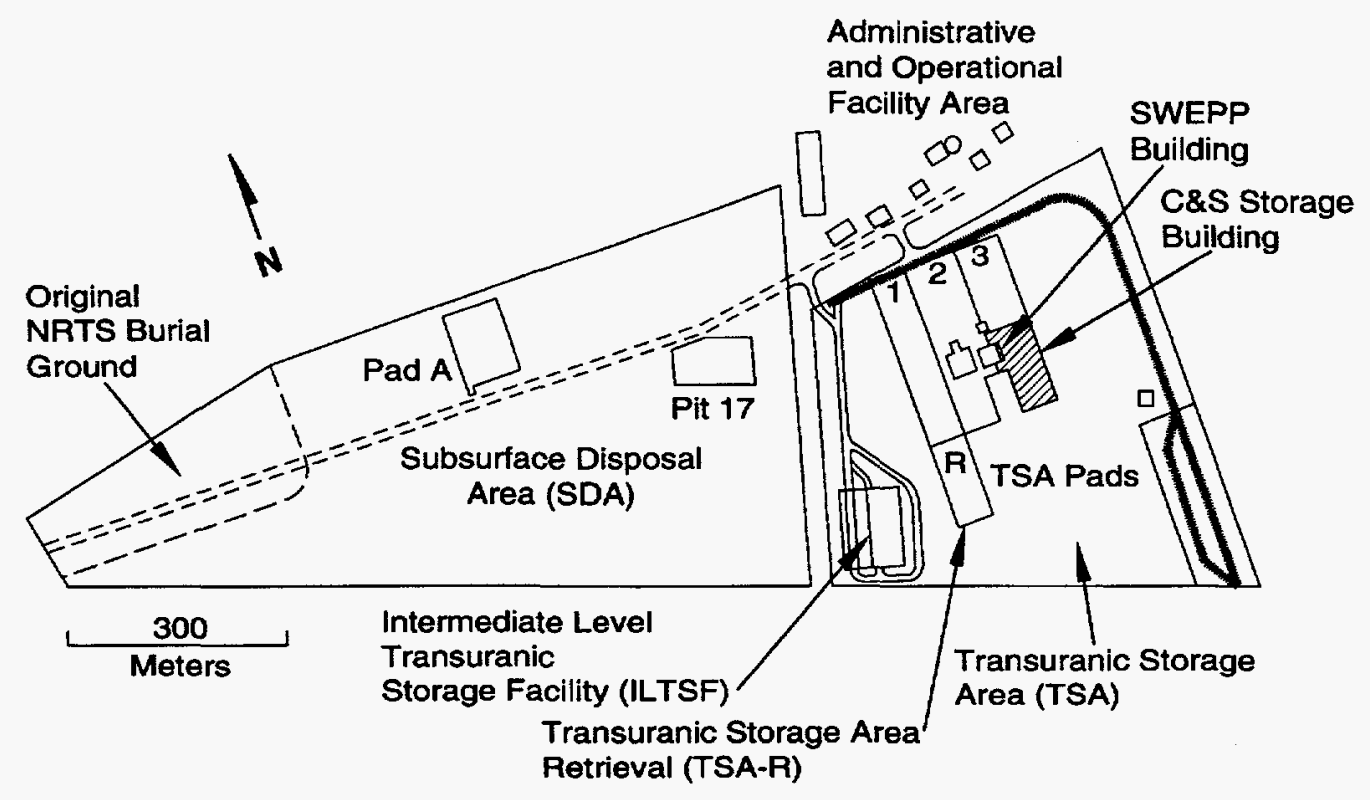

8930038

Figure 2. Map of the Radioactive Waste Management Complex.

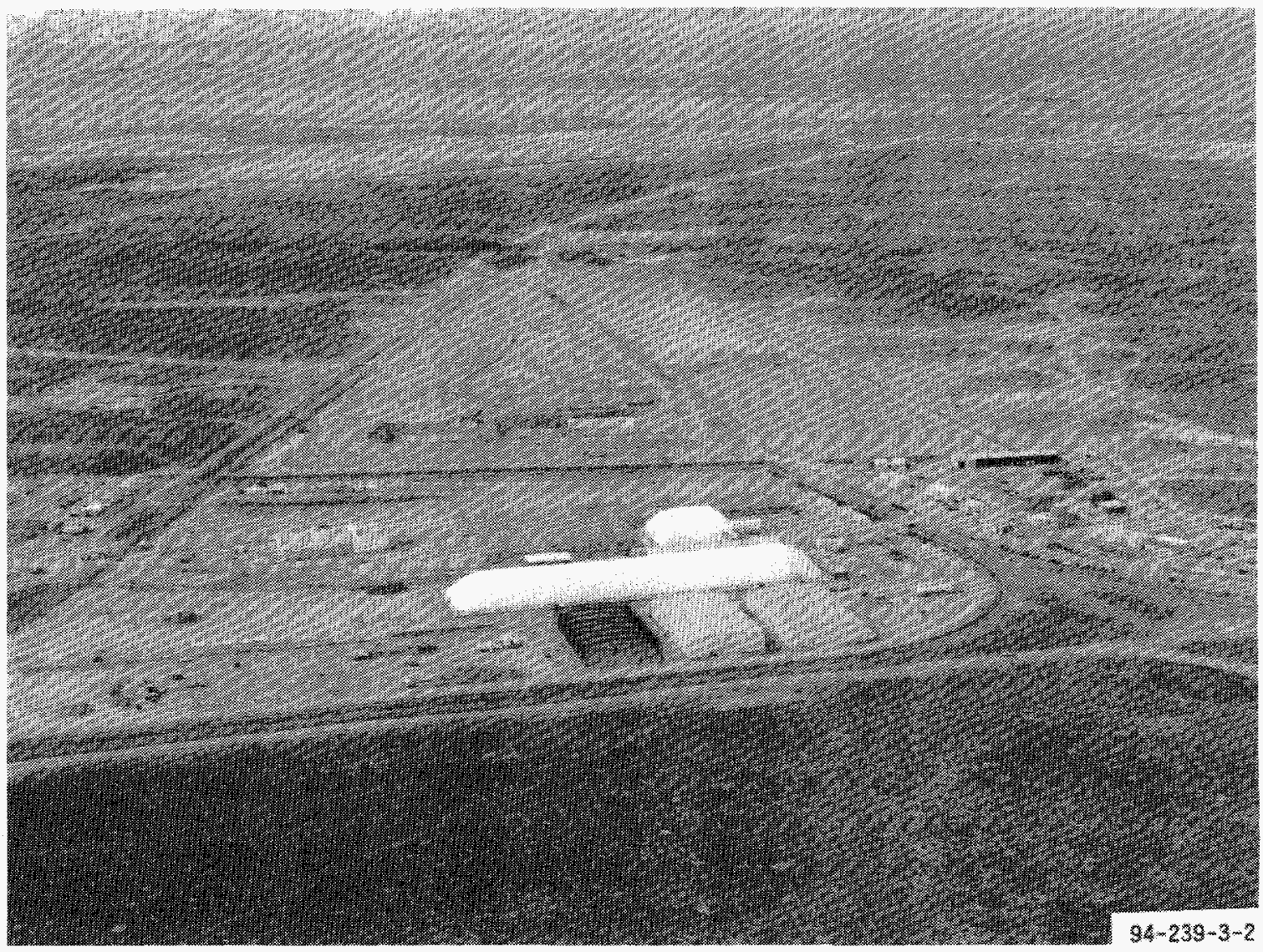

Figure 3. Aerial photograph of the Radioactive Waste Management Complex (facing west). 


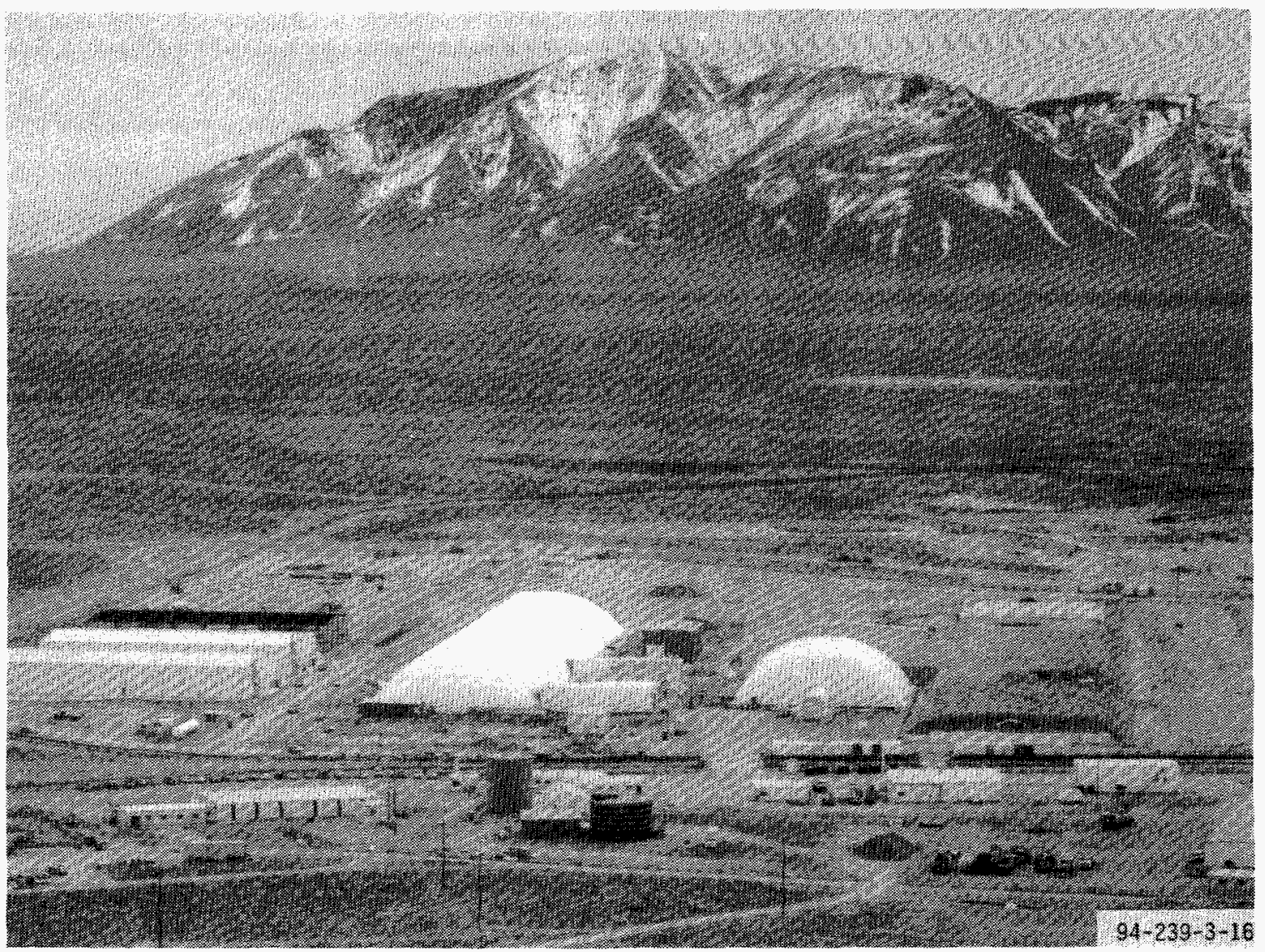

Figure 4. Aerial photograph of the Stored Waste Examination Pilot Plant (facing south).

\section{Waste Experimental Reduction Facility}

WERF is located in the south-central portion of the INEL (see Figure 5) about $8 \mathrm{~km}$ northeast of the Central Facilities Area (CFA). It is located in the decommissioned and modified Special Power Excursion Reactor Test No. 3 (SPERT-III) facility and consists of a concrete block building (PER-609) with high bay and basement operating areas. Incineration and stabilization processes are conducted in this facility. Compaction and sizing activities are performed in a metal building (PER-622) located to the east of PER-609. Transient storage pads for pre- and post-process waste are located adjacent to the facility.

Other facilities at WERF include

- $\quad$ PER-623 - The WERF Waste Stor- age Building has been recently constructed for storage of mixed waste, hazardous wastes, and contaminated lead. This building has not been used yet for storage of these materials.

- $\quad$ PER-635 - This building originally housed the size reduction operations and is currently used for equipment storage and is proposed to house the nonincinerable mixed low-level waste treatment activities after upgrades.

- $\quad$ PER-641 - The WERF Operations Support Building was recently constructed to house support personnel. 


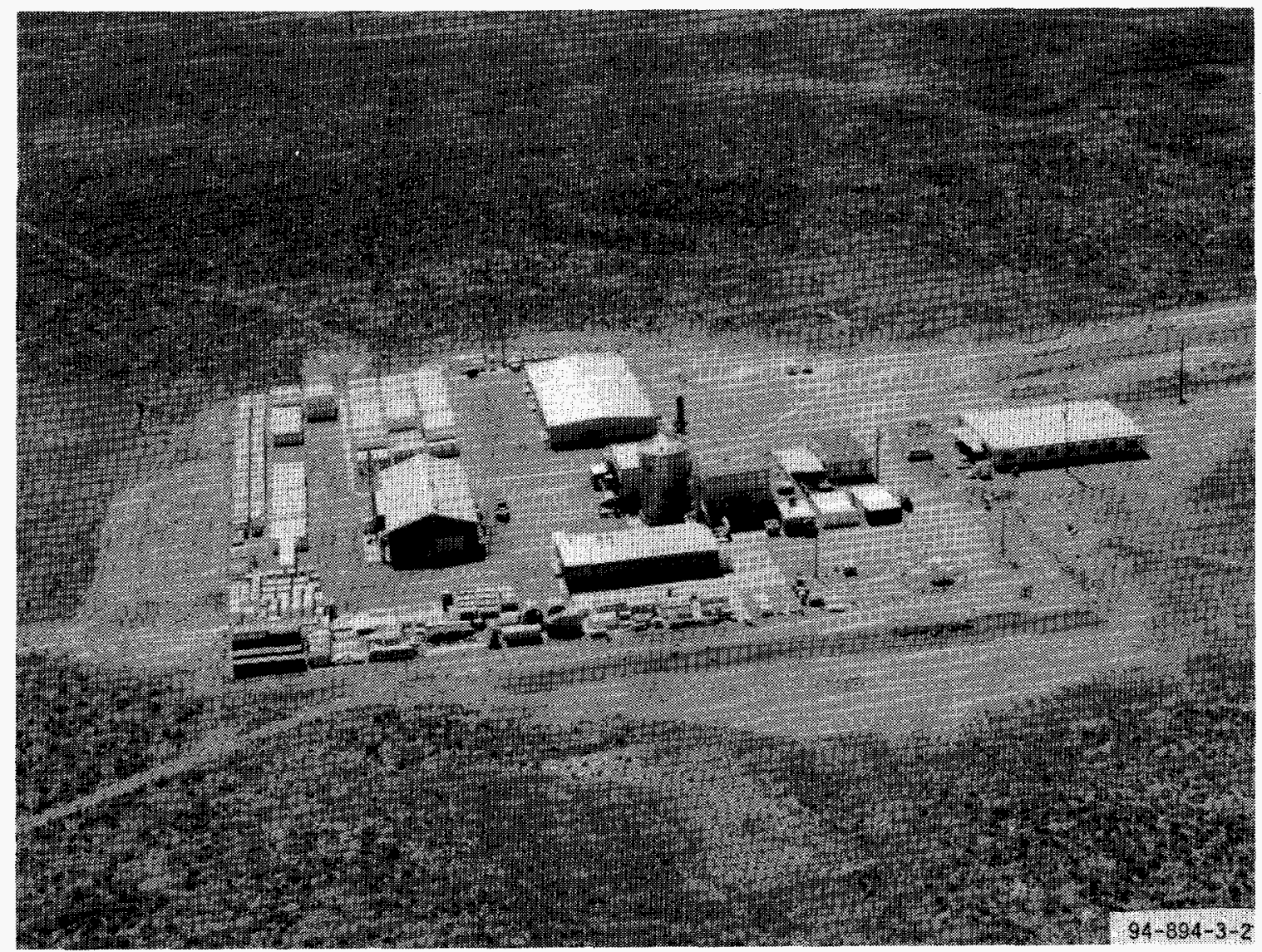

Figure 5. Aerial photograph of the Waste Experimental Reduction Facility (facing east).

WERF was established in 1982 to demonstrate that commercially available volume reduction techniques could be used to significantly reduce the volume associated with LLW disposal. Specifically, WERF provides treatment for volume reduction of solid LLW through compaction, incineration, and sizing operations. WERF also provides treatment of liquid LLW, hazardous wastes, and mixed LLW through incineration and stabilization. Exhaust gases from WERF activities are filtered through baghouse and high- efficiency particulate air filters prior to discharge.

\section{Mixed Waste Storage Facility}

The MWSF is the temporary storage facility for mixed waste at the INEL. It is housed in the decontaminated and decommissioned SPERT-IV reactor building (PBF-613). The building, which was constructed in 1960 , consists of a high bay and two low-bay wings. The high bay is a
$22 \times 15 \times 14-\mathrm{m}$ steel-girded, reinforced concrete, cinder block structure with a deep basement, and a metal roof. The total capacity of stored mixed waste is $365,208-\mathrm{L}$ drums, or equivalent. Cargo containers in the parking area adjacent to the MWSF are used for storage of mixed waste solids, including lead. No flammable liquids or reactive wastes are stored in the cargo containers.

\section{Stationary Low-Power No. 1 Surplus Area}

The SL-1 surplus area is located in the southcentral portion of the INEL, about $7.2 \mathrm{~km}$ north of the southern INEL boundary. The total area within the SL-1 Burial Ground exclusion fence is about $1 \mathrm{~km}^{2}$. No surface facilities have been constructed within the fence. The area contains most of the SL-1 dismantled reactor building, radiologically contaminated equipment, about $750 \mathrm{~m}^{3}$ of radiologically contaminated dirt and gravel, 
and decontamination waste in one trench and two pits.

\section{Organic-Moderated Reactor Experiment}

The OMRE area is located in the south-central portion of the INEL, about $7.6 \mathrm{~km}$ north of the southern INEL boundary, and occupies about $0.7 \mathrm{~km}^{2}$. The OMRE project was completed in 1963 , and the facility was decontaminated and decommissioned in 1979. The building and underground reactor were disassembled; the radiologically contaminated material was disposed of at the RWMC, and uncontaminated parts were sold as scrap. The leach pond was backfilled with soil, and the entire area was revegetated with a mixture of native grasses in 1981. No waste was buried within the OMRE boundaries, and no surface facilities remain there today. 


\section{MONITORING METHODS AND RESULTS}

The remainder of this report discusses the monitoring methods and results for calendar year 1994 with the major portion being radiological monitoring of INEL Waste Management Facilities. Radiological surveillance includes the following topics: (a) airborne particulates, (b) RWMC surface water run-off, (c) soils, (d) biota (vegetation and small mammals), (e) penetrating radiation, and (f) surface radiation. Table 1 shows the RESP activities performed at these Waste Management Facilities. In addition, this report briefly discusses groundwater monitoring at the RWMC by the USGS.

Appendices that discuss Quality Assurance, Appendix A; Detection Limits, Appendix B; Statistical Analysis Methods, Appendix C; and Environmental Standards, Appendix D, are also included. Detailed information on radiological analyses of all sample media is discussed in Appendix $B$.

\section{Ambient Air Monitoring}

Air is considered to be a critical pathway of contaminants through the environment. ${ }^{11}$ Airborne materials from the RWMC are predominantly fugitive dusts with small amounts of sorbed radionuclides. The general approach to monitoring an area source, such as the fugitive dusts at the RWMC, is to monitor the perimeter of the facility.

The 1983 MAR (EGG 1983a) provides much of the rationale for the current ambient air monitoring design. ${ }^{12}$ As recommended by the MAR, the number of high-volume air monitor locations around the SDA was reduced to seven. A replicate monitor and a control location were also added to the air monitoring system. In addition, also based on the MAR comments, high-volume air monitors were replaced in 1986 with low-volume (LV) air monitors that operate at $0.14 \mathrm{~m}^{3} / \mathrm{min}$ (see Figure 6). Particulate material is collected on a membrane filter (Gelman Model Versapor-1200, $1.2 \mu \mathrm{m}, 102-\mathrm{mm}$ diameter).

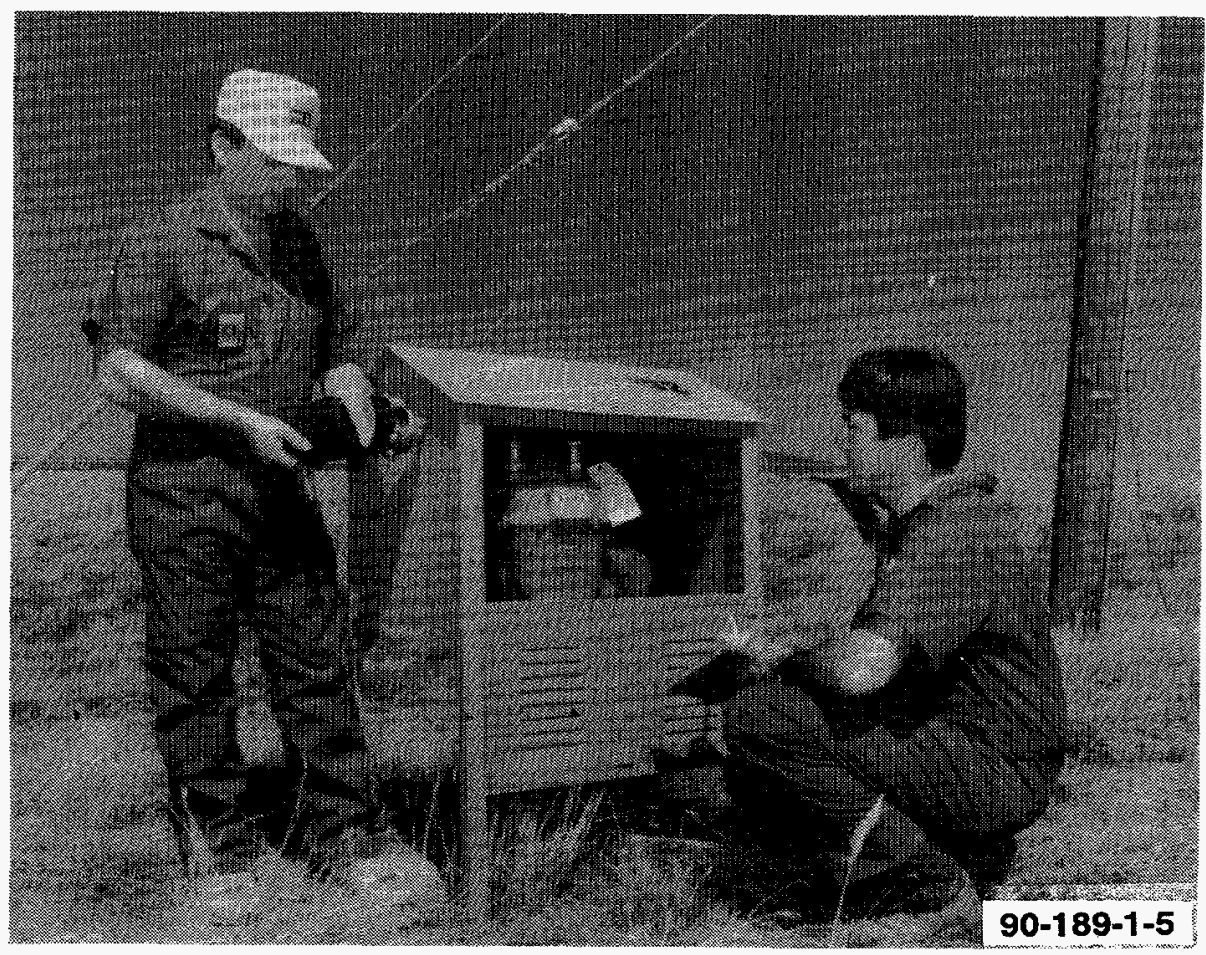

Figure 6. Collection of particulate air filter from LV air monitor. 
During July 1992, most of the existing suspended particulate (SP) air monitors were replaced with intermediate-flow $\left(0.11 \mathrm{~m}^{3} / \mathrm{min}\right)$ particulate matter $\leq 10 \mu \mathrm{m}\left(\mathrm{PM}_{10}\right)$ air monitors (see Figures 7 and 8). The $\mathrm{PM}_{10}$ air monitors use the same membrane filter as the SP air monitors, and the $\mathrm{PM}_{10}$ monitors sample particulates less than $10 \mu \mathrm{m}$ in size, which is considered to be the respirable fraction. The $\mathrm{PM}_{10}$ fraction is also the range of particle sizes that can be transported to offsite locations by wind. Measuring the respirable fraction provides data which meets the general RESP objective for providing data which may be used for dose calculations.

SP air monitors remain at strategic locations at RWMC and WERF, including Location 300 of WERF (see Figures 9 and 10). One air monitor remains at Location 2 of the SDA while two others remain at Locations 20 and 26 of SWEPP (see Figure 9).

Replicate $\mathrm{PM}_{10}$ samples are taken at Location 4.3 at the RWMC as part of the RESP Quality Assurance/Quality Control Program (see Figure 9). Control sample Locations 15 and 15.3 for the RWMC are at the Experimental Breeder Reactor No. I (EBR-I) area, approximately $3 \mathrm{~km}$ east-northeast of the RWMC. The WERF control sample location, which serves both WERF and MWSF, is next to the INEL Main Gate, Building 603 (see Figure 11). The prime factors influencing the selection of monitor locations were prevailing wind patterns and accessibility and availability of electrical power.

RESP personnel sampled the ambient air for radioactive particulates during 1994 at the RWMC, WERF, and MWSF. In addition to the general RESP objectives, the specific objectives of the ambient air sampling are as follows: (a) determine concentrations of airborne radionuclides in the vicinity of INEL Waste Management Facilities, (b) report comparisons of measured concentrations to reference levels based on derived concentration guides (DCGs) for the public given in DOE Order 5400.5, ${ }^{13}$ and (c) detect and report significant trends in measured concentrations of airborne radionuclides.

Air filters are collected and analyzed semimonthly for gross alpha and gross beta activity, and monthly composites at each location are analyzed quantitatively for gamma-emitting radionuclides. All filters from the RWMC are also composited on a quarterly basis and analyzed for specific alpha- and beta-emitting radionuclides. The statistical approach applied to analyze the data is presented in Appendix C. RESP samples are compared to data supplied by SESP from air monitors located both onsite and offsite.

The primary purpose for gross alpha analysis is to rapidly detect significant changes in airborne alpha activity at the RWMC. The gross alpha results are also used as a criterion to screen samples for immediate radiochemical analyses for specific alpha-emitters.

Results of gross beta analysis of the air filters are evaluated to determine if there are any significant increases in the sample radioactivity that may require more immediate or more in-depth analysis by gamma spectrometry or radiochemistry. Gross beta analysis is thus used as a quick and inexpensive screening tool. The results are also used to indicate any trends in environmental radioactivity.

Lockheed Martin Idaho evaluates gross beta results semimonthly by comparing them with historical and background data for an indication of trends using a log concentration-versus-time plot. Control concentrations, detection limits, and alert levels are compared for each plot. Alert levels are $25 \%$ of the most restrictive DCGs for the public. Comparisons are made between stations and with the control monitors, using analysis of variance (see Appendix C). The RESP also compares gross beta activity to DCGs. Measured concentrations are compared to the DCGs to provide a point of reference for interpreting the results (see Appendix D). Sr-90 and Cs-137 are the most likely waste-related beta-emitting radionuclides to be found at the RWMC. Of these two, $\mathrm{Sr}-90$ has the more restrictive DCG. For this rea- 


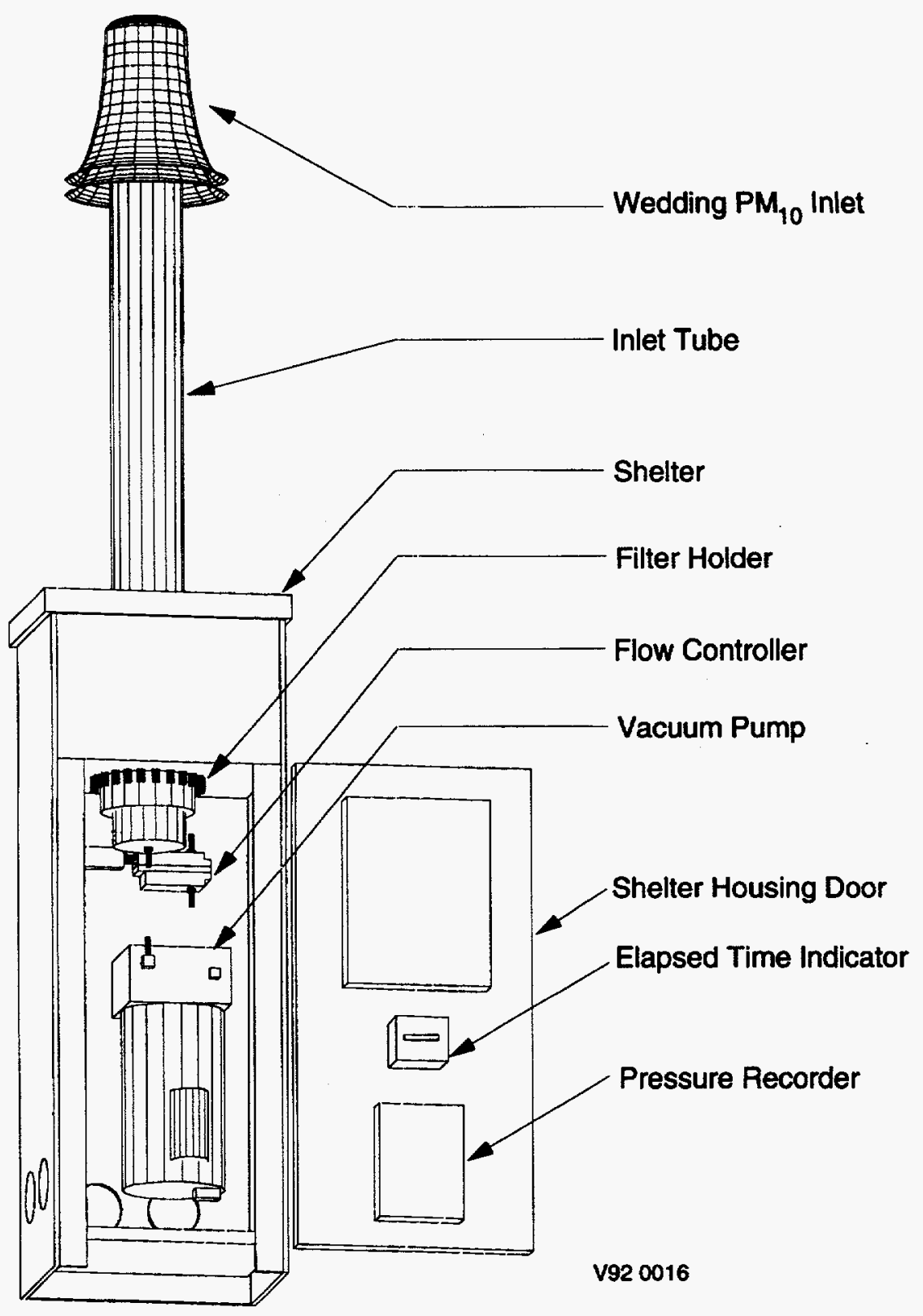

Figure 7. $\mathrm{PM}_{10}$ air monitor. 


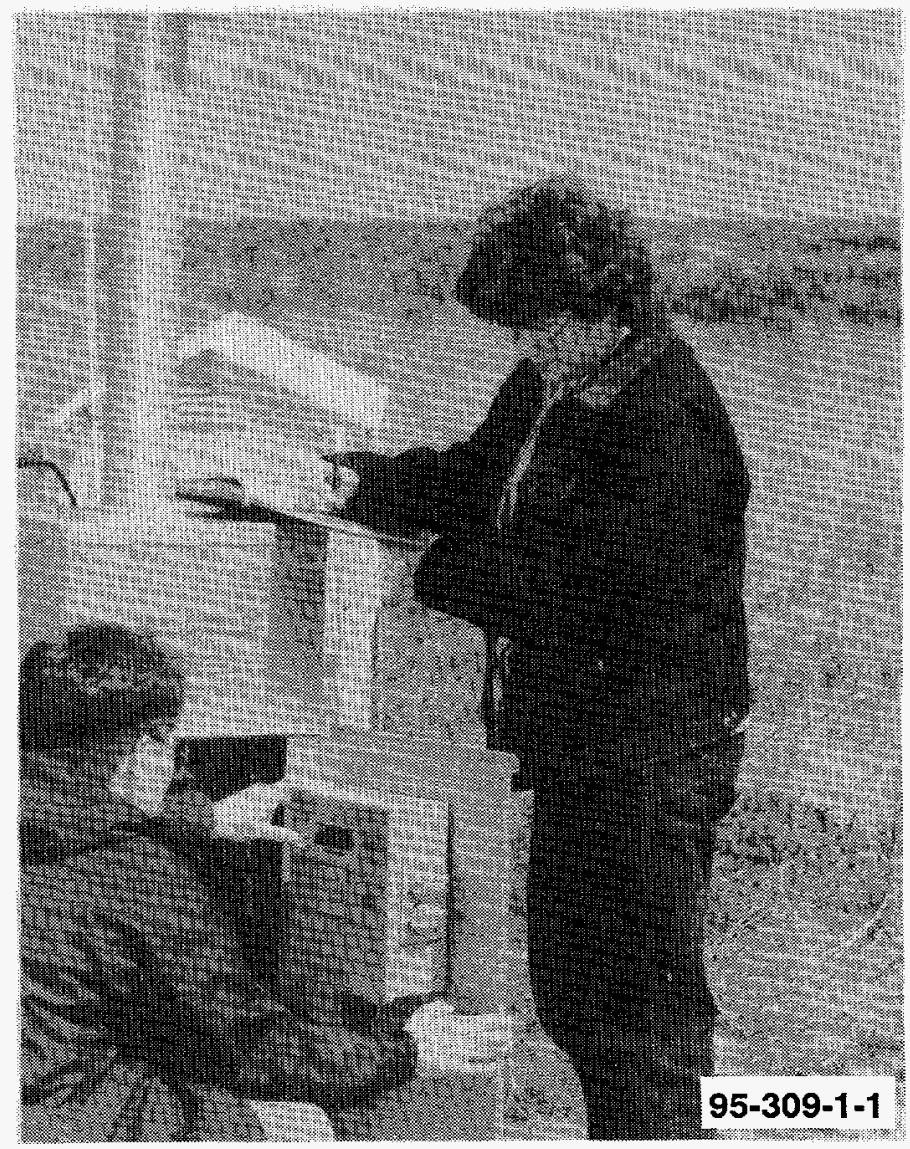

Figure 8. Collection of particulate air filter from a $\mathrm{PM}_{10}$ air monitor.

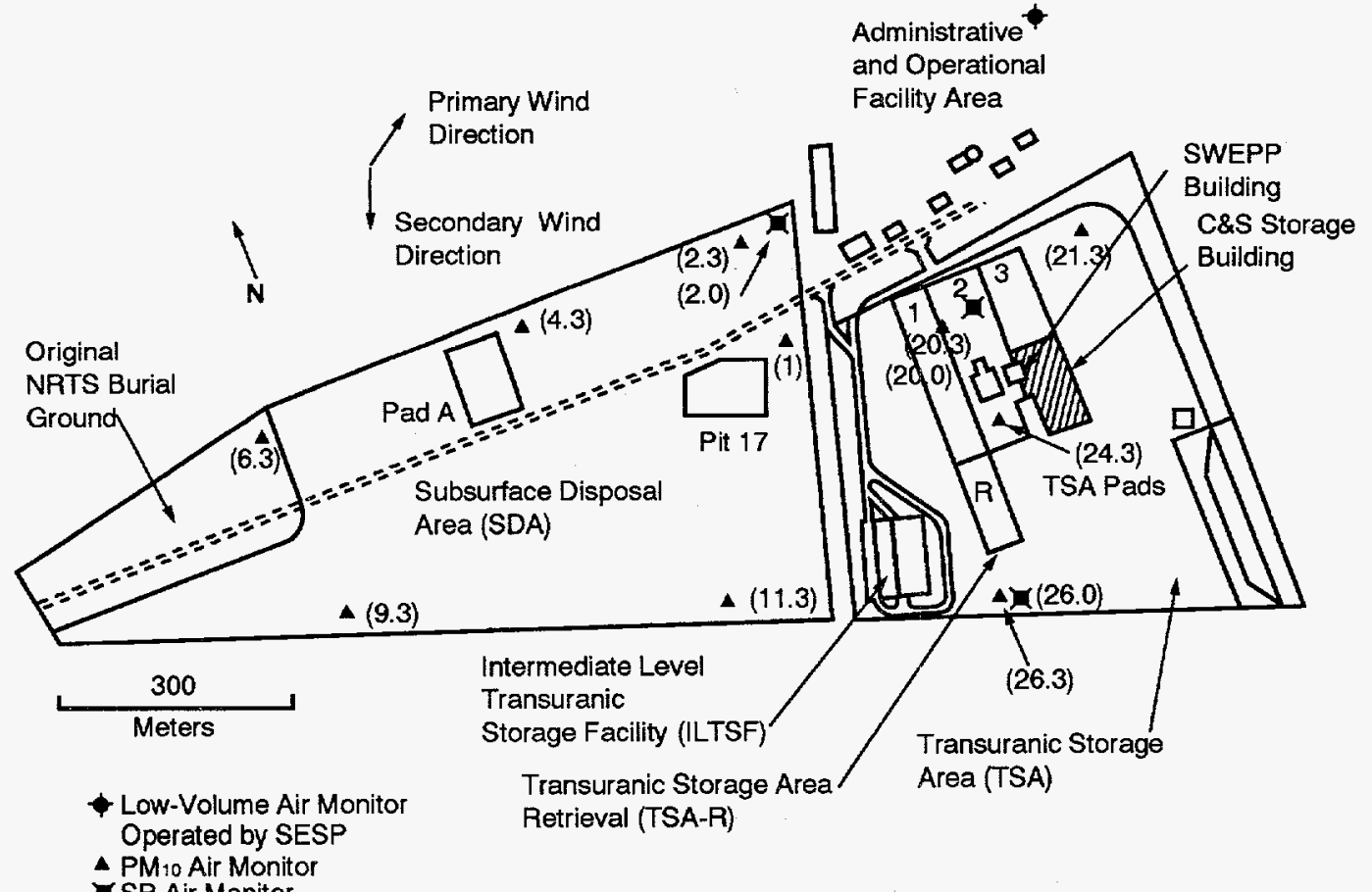

VG95 0285

Figure 9. RWMC SP and $\mathrm{PM}_{10}$ air monitoring locations. 


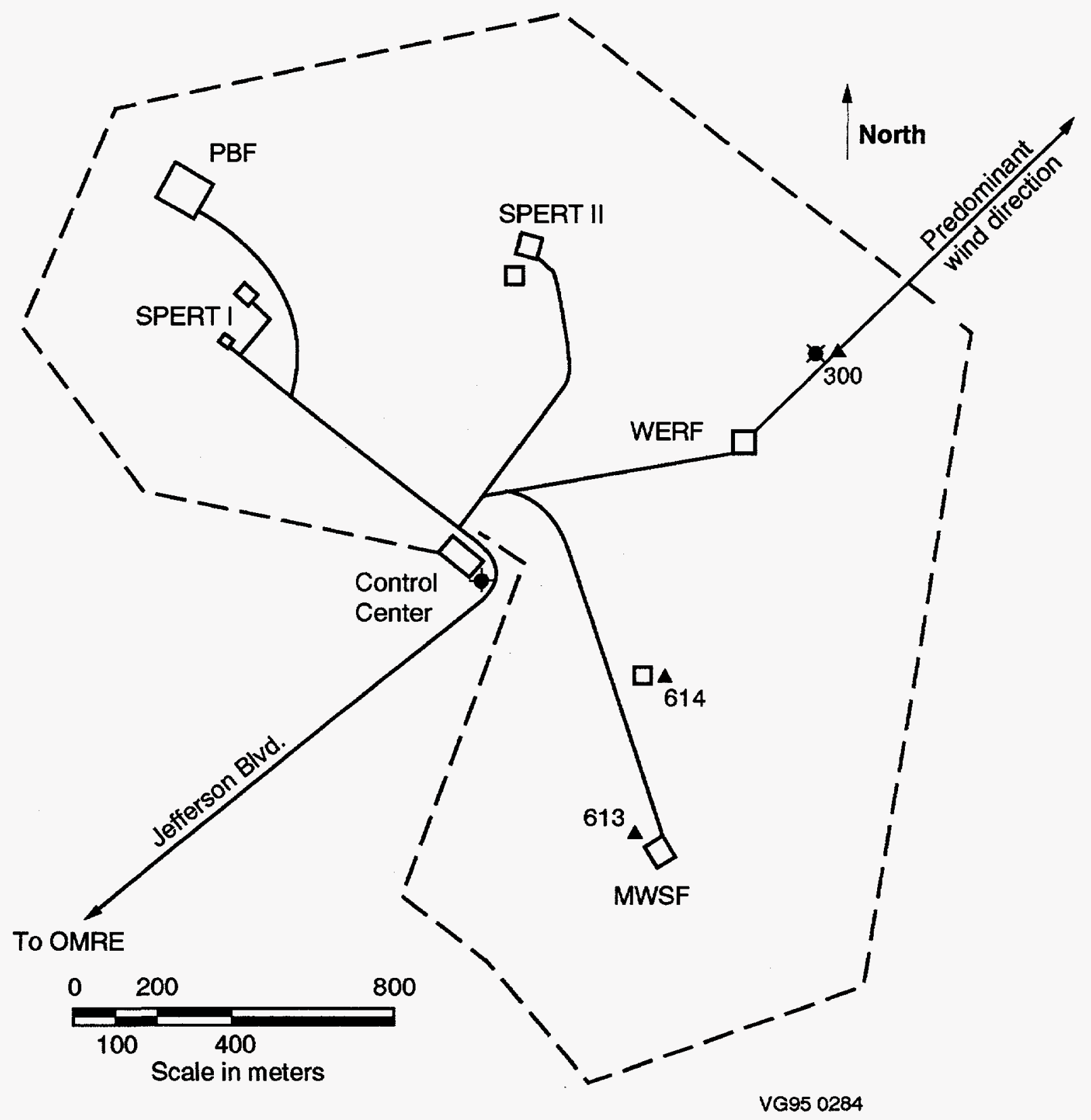

Low-volume air monitor operated by SESP

- LITCO PM10 air monitor

a LITCO SP air monitor

Figure 10. WERF air monitoring locations. 


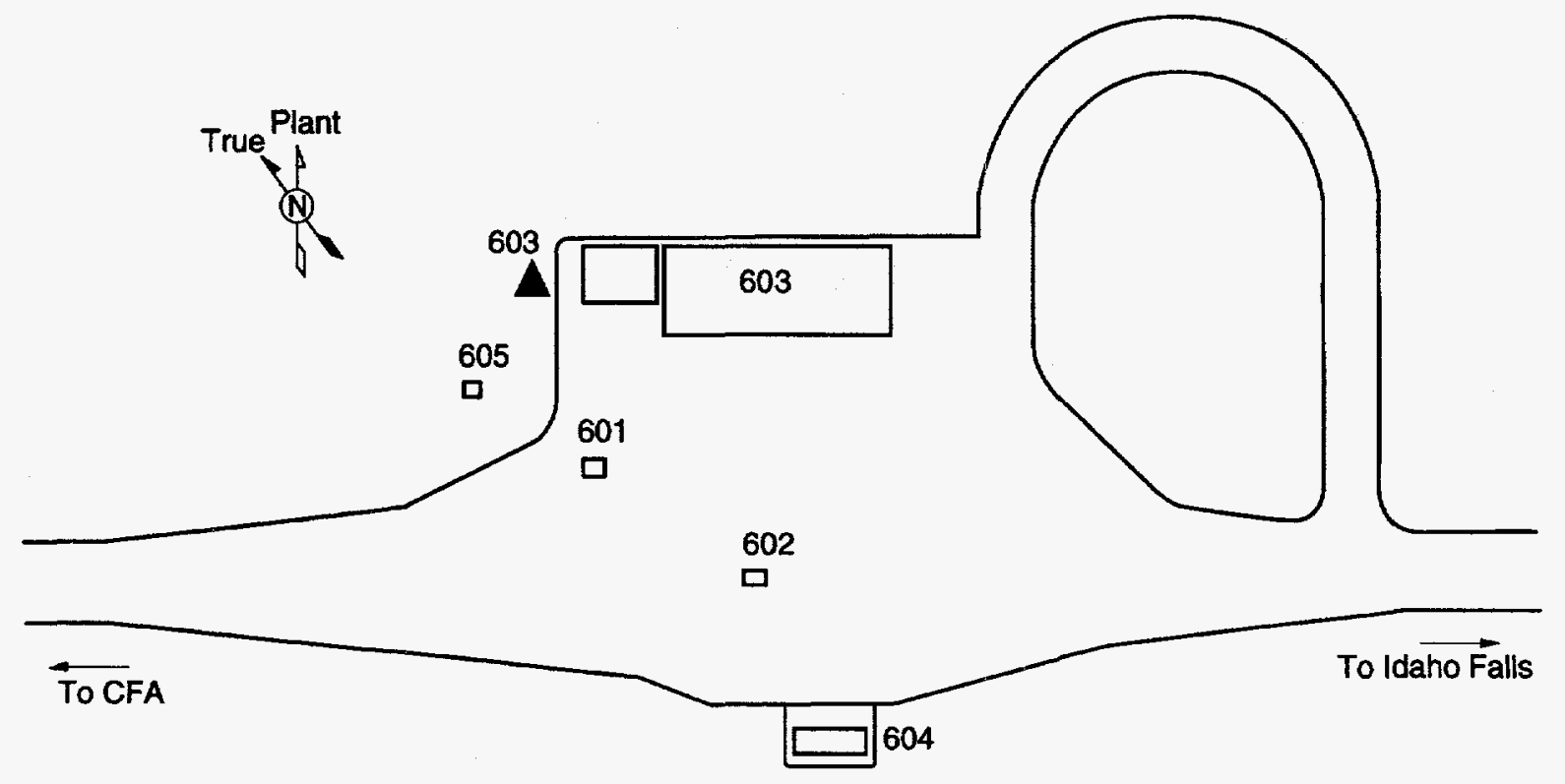

P94 0017

$\mathrm{PM}_{10}$ air sampler location

Figure 11. WERF air monitoring control location at the Main Guard Gate.

son, the Sr-90 DCG was adopted as the equivalent gross beta DCG for airborne particulates (see Appendix D). ( $\mathrm{Pu}-241$ is also a low-energy, beta emitter and has a more restrictive DCG than Sr-90; however, it is generally detected through its alpha- and gamma-emitting daughter, Am-241.)

\section{Trend Analysis}

Graphs of gross alpha and gross beta concentrations over time from all locations (except the two control locations) are given in Figures 12-15. For both alpha and beta concentrations, there is one graph for the $\mathrm{PM}_{10}$ monitor results and one for the SP results.
To provide an indication of the general trend in values over time, data in the graphs were smoothed using polynomial smoothing. Second degree polynomials were fit to all four data sets, gross alpha and beta for both $\mathrm{PM}_{10}$ and SP monitors. In all four instances, concentrations declined from January until around midyear, then began gradually increasing until the end of the year. In all instances, except for gross beta from SP monitors, yearly peak values occurred at the end of the year. For gross beta data from the SP monitors, the year end value was slightly less than at the start of the year. These trends are similar to those noted for 1993 because midyear concentrations were lowest and year end values were generally higher than the beginning values.

One reason for the difference in the measured values from the two monitor types is that the $\mathrm{PM}_{10}$ monitors are designed to admit only parti- 


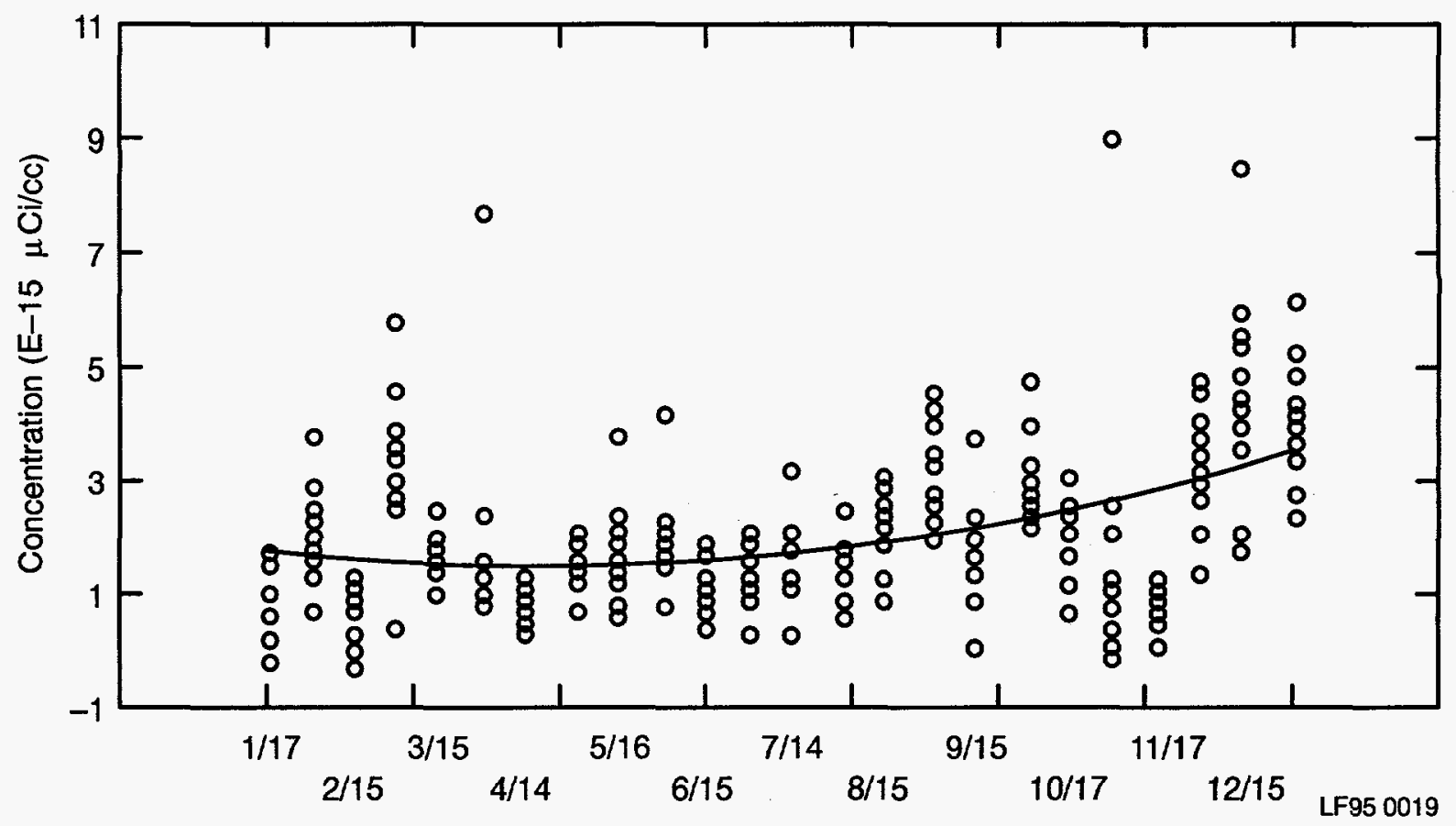

Figure 12. 1994 gross alpha concentrations for $\mathrm{PM}_{10}$ air monitors using second order polynomial smoothing.

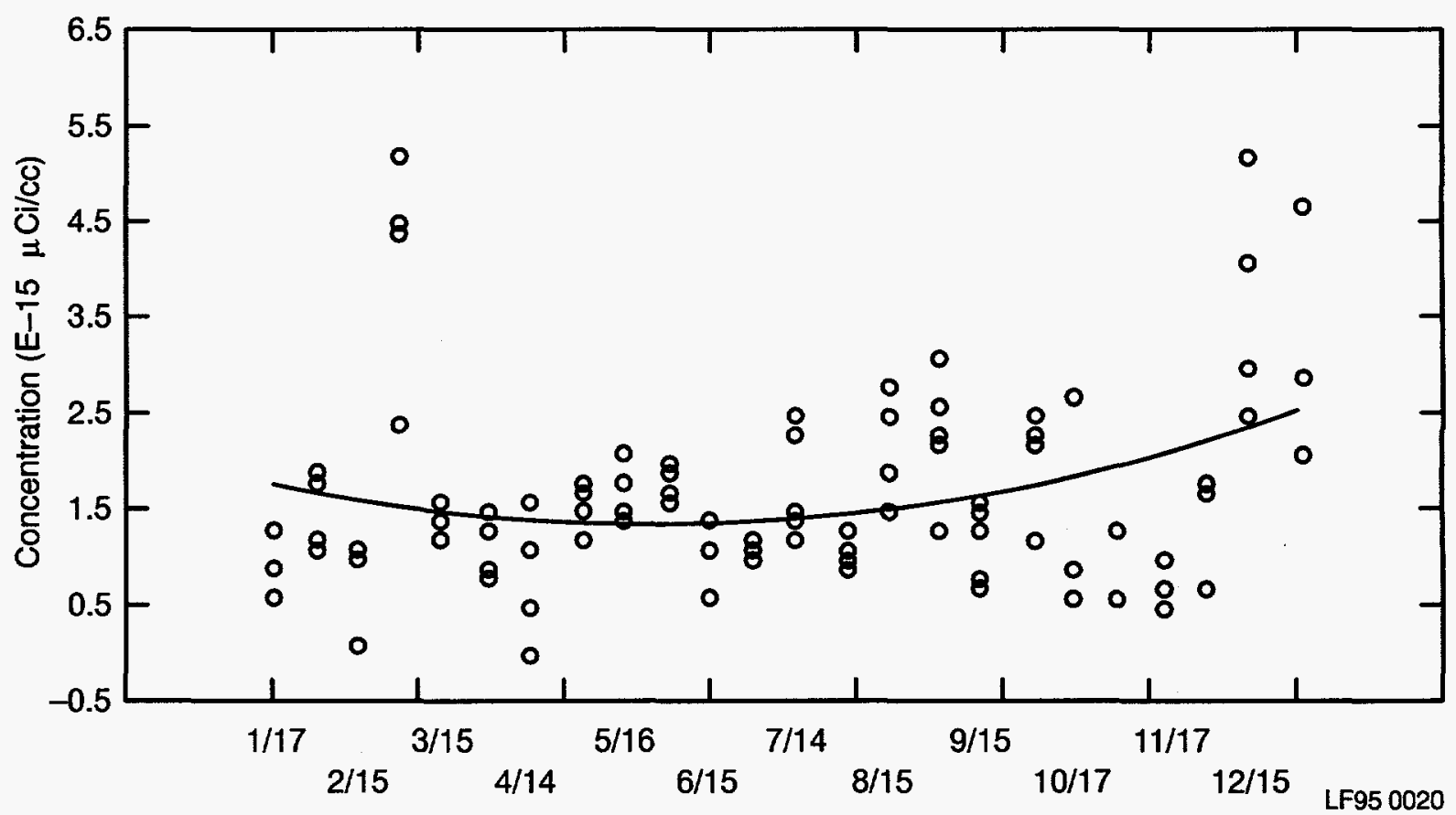

Figure 13. 1994 gross alpha concentrations for SP air monitors using second order polynomial smoothing. 


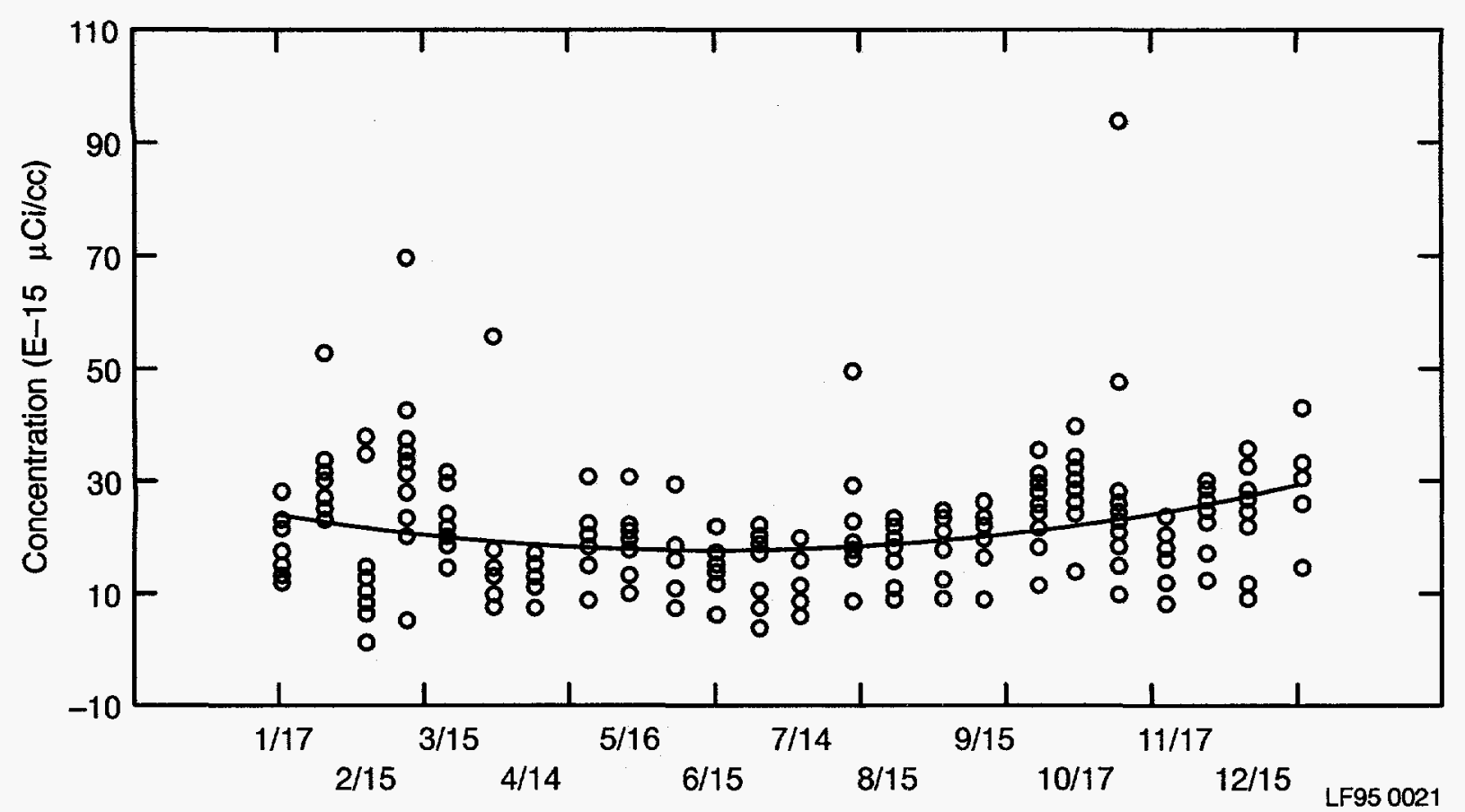

Figure 14. 1994 gross beta concentrations for $\mathrm{PM}_{10}$ air monitors using second order polynomial smoothing.

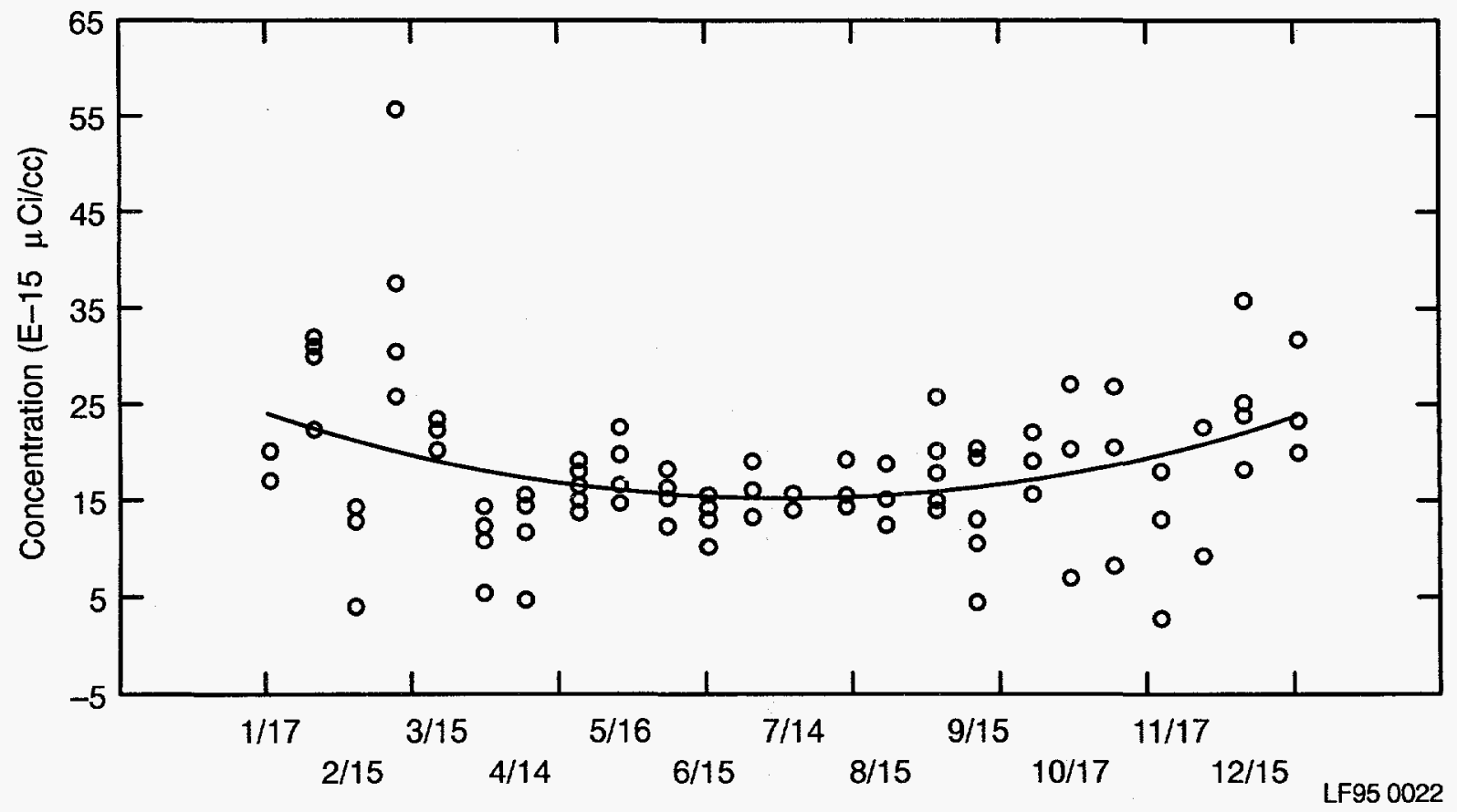

Figure 15. 1994 gross beta concentrations for SP air monitors using second order polynomial smoothing. 
cles less than 10 microns in diameter while the SPs admit larger particles. The particle size restriction of the $\mathrm{PM}_{10}$ monitors has been determined to be appropriate for pathway modeling. The differences seen in Figures 16 and 17 in the average monitor concentrations might be attributed to fluctuations in the activity distributions rising from natural releases from processes operating at a particular time. In any case, the significant differences in monitors must be taken into account in any analysis of the data.

\section{Comparisons by Facility}

A set of Box and Whisker plots is presented which compare gross alpha and gross beta concentrations for each monitor type by facility. Summarized 1993 and 1994 data, by facility and monitor type, are presented in Figures 18 and 19 to provide an indication of short term changes in levels. Corresponding summary statistics (e.g., means, medians, maximum, and minimum values) are given in Tables 2 and 3.

As with the 1993 analysis of gross alpha values, very little variability was seen among facili- ties during 1994. For the SP monitors, slight increases in median values from 1993 to 1994 were seen at two of the four locations, with slight decreases at the remaining two locations. All five locations with $\mathrm{PM}_{10}$ monitors indicated a slight increase in median values from 1993 to 1994 . To test for statistical significance of the variations in medians from 1993 to 1994, the Kruskal-Wallis significance tests were performed for each facility. All the changes in median values from 1993 to 1994 of $\mathrm{PM}_{10}$ monitors were found to be statistically significant at the .05 level, except for the WERF control location. None of the median changes seen in the SP monitors were found to be statistically significant.

In general, slight increases in the median gross beta values from 1993 to 1994 were seen for the $\mathrm{PM}_{10}$ monitors at all facilities. For the SP monitors, slight decreases were seen at all facilities except for the WERF, which noted a slight increase. However, the Kruskal-Wallis test indicated that only median changes for the $\mathrm{PM}_{10}$ monitors located at the SDA and WERF and the SP monitor at the SDA were statistically significant.

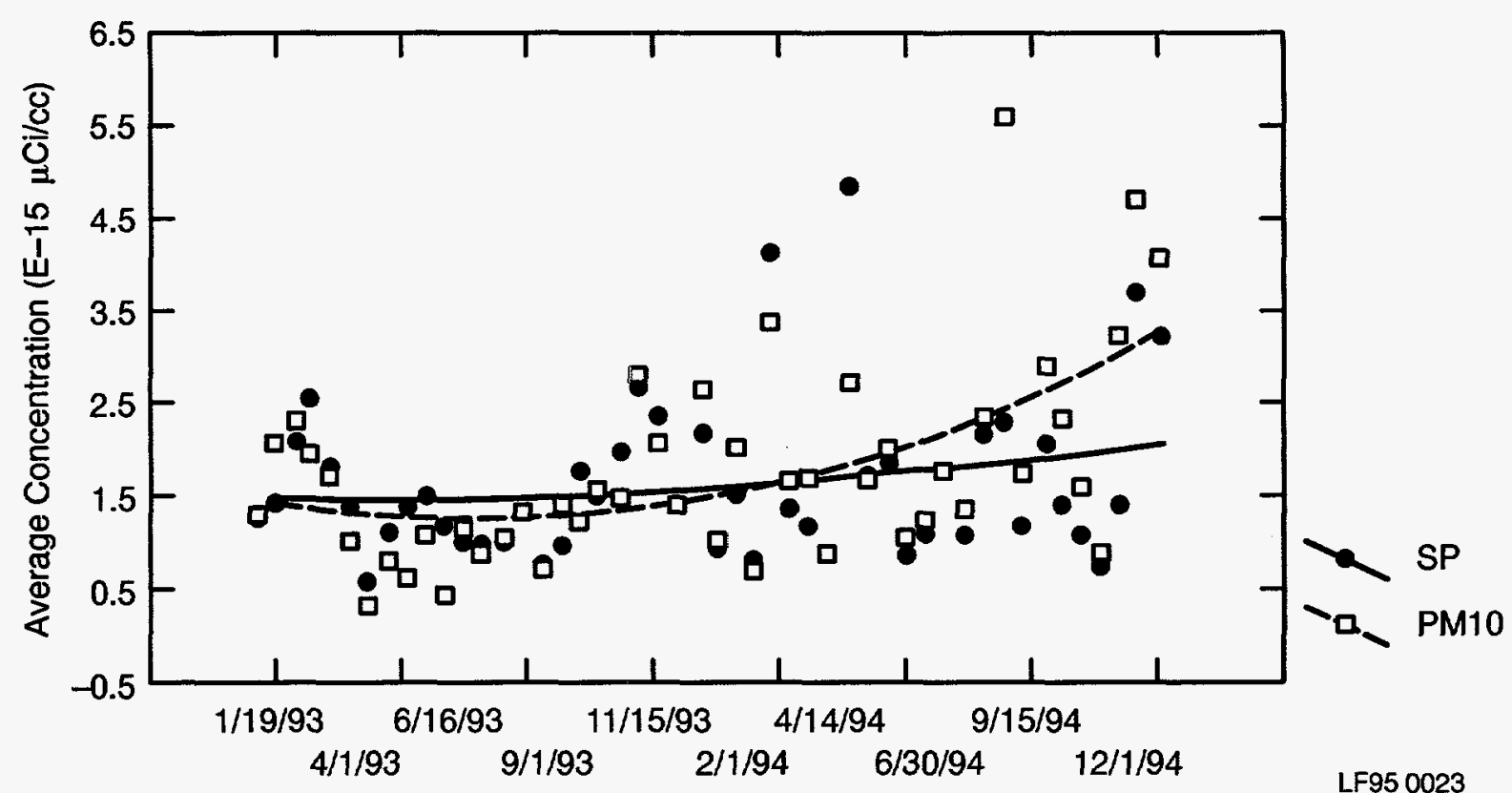

Figure 16. Gross alpha concentrations by monitor type for Locations $2,15,20,26$, and 300 using third order polynomial smoothing. 


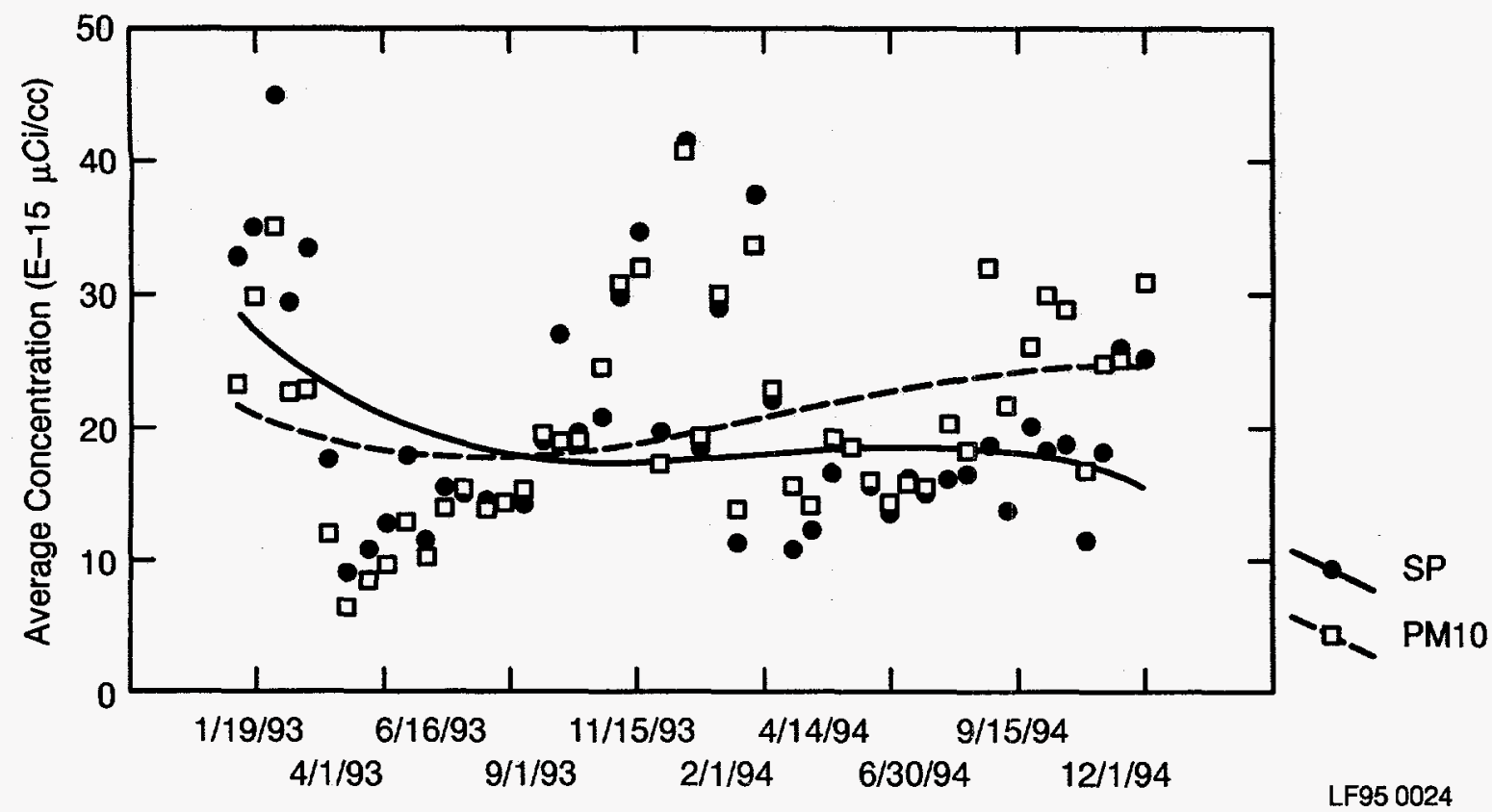

Figure 17. Gross beta concentrations by monitor type for Locations $2,15,20,26$, and 300 using third order polynomial smoothing.
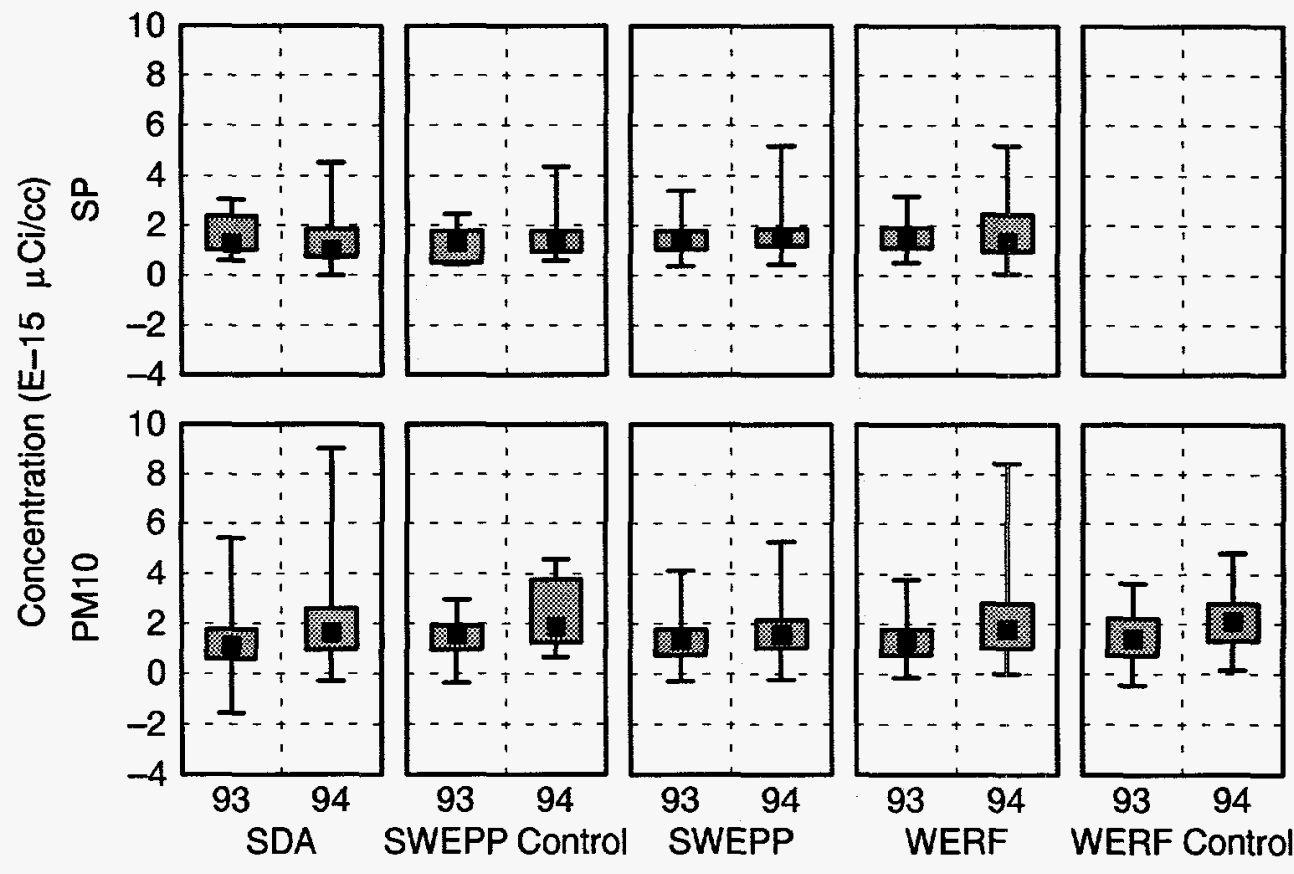

I Min-max

$25-75 \%$

- Median

LF95 0025

Figure 18. 1993 and 1994 Box and Whisker plots of the gross alpha concentrations by facility and monitor type. 


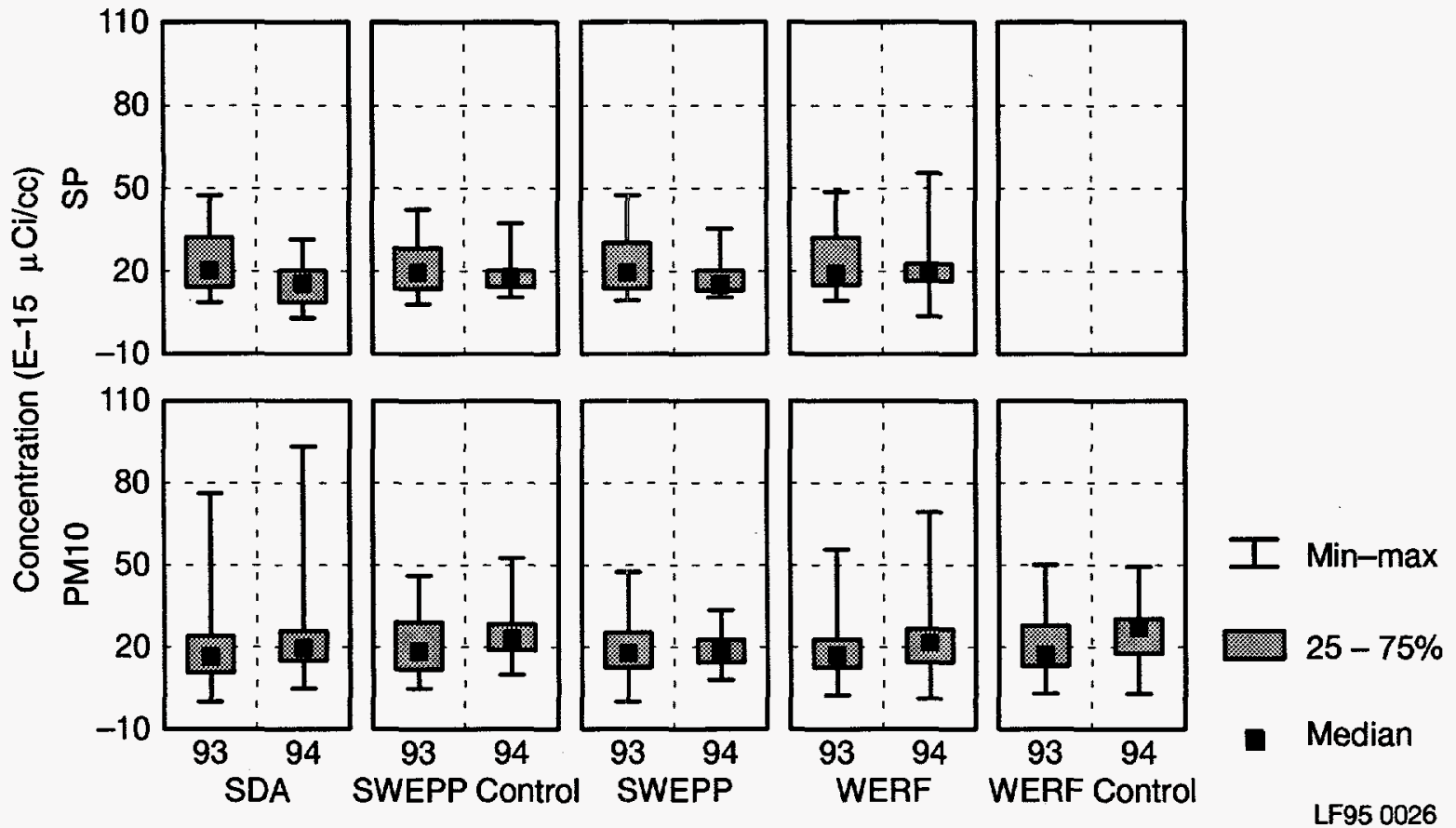

Figure 19. 1993 and 1994 Box and Whisker plots of the gross beta concentrations by facility and monitor type.

Table 2. Summary statistics for gross alpha concentrations (all concentration values are $\mathrm{E}-15 \mu \mathrm{Ci} / \mathrm{cc}$ )

\begin{tabular}{llcccccc}
\hline $\begin{array}{l}\text { Monitor } \\
\text { Type }\end{array}$ & Facility & Year & $\mathrm{N}$ & Mean & Median & Minimum & Maximum \\
\hline SP & SDA & 93 & 20 & 1.7 & 1.2 & 0.7 & 3.0 \\
& & 94 & 24 & 1.4 & 1.1 & 0.0 & 4.5 \\
& SWEPP & 93 & 36 & 1.5 & 1.4 & 0.4 & 3.5 \\
& & 94 & 31 & 1.8 & 1.5 & 0.5 & 5.2 \\
& WERF & 93 & 24 & 1.6 & 1.4 & 0.6 & 3.2 \\
& & 94 & 23 & 2.5 & 1.3 & 0.1 & 18.0 \\
& SWEPP & 93 & 23 & 1.3 & 1.3 & 0.5 & 2.5 \\
PM $_{10}$ & Control & 94 & 21 & 1.6 & 1.4 & 0.6 & 4.4 \\
& SDA & 93 & 124 & 1.3 & 1.1 & -1.6 & 5.4 \\
& & 94 & 153 & 2.0 & 1.7 & -0.3 & 9.0 \\
& SWEPP & 93 & 108 & 1.3 & 1.3 & -0.3 & 4.1 \\
& & 94 & 92 & 1.8 & 1.6 & -0.2 & 5.3 \\
& WERF & 93 & 72 & 1.4 & 1.3 & -0.1 & 3.8 \\
& & 94 & 64 & 2.5 & 1.9 & 0.0 & 18.0 \\
& SWEPP & 93 & 23 & 1.4 & 1.5 & -0.4 & 3.0 \\
& Control & 94 & 23 & 2.4 & 1.9 & 0.7 & 4.6 \\
& WERF & 93 & 22 & 1.6 & 1.5 & -0.4 & 3.7 \\
& Control & 94 & 24 & 2.2 & 2.2 & 0.2 & 4.9 \\
\hline
\end{tabular}


Table 3. Summary statistics for gross beta concentrations (all concentration values are $\mathrm{E}-15 \mu \mathrm{Ci} / \mathrm{cc})$.

\begin{tabular}{|c|c|c|c|c|c|c|c|}
\hline $\begin{array}{l}\text { Monitor } \\
\text { Type }\end{array}$ & Facility & Year & $\mathrm{N}$ & Mean & Median & Minimum & Maximum \\
\hline \multirow[t]{10}{*}{$S P$} & SDA & 93 & 20 & 23.4 & 20.0 & 9.1 & 47.8 \\
\hline & & 94 & 24 & 15.4 & 15.4 & 3.1 & 31.4 \\
\hline & SWEPP & 93 & 36 & 22.8 & 19.7 & 9.5 & 47.8 \\
\hline & & 94 & 31 & 17.7 & 15.4 & 11.1 & 36.2 \\
\hline & WERF & 93 & 24 & 24.0 & 19.2 & 9.8 & 50.0 \\
\hline & & 94 & 23 & 21.1 & 19.6 & 4.2 & 56.0 \\
\hline & SWEPP & 93 & 23 & 21.9 & 20.0 & 8.2 & 42.4 \\
\hline & Control & 94 & 21 & 18.5 & 18.2 & 10.8 & 37.8 \\
\hline & WERF & 93 & 24 & 24.0 & 19.2 & 9.8 & 49.6 \\
\hline & Control & 94 & 23 & 21.1 & 19.6 & 4.2 & 56.0 \\
\hline \multirow[t]{10}{*}{$\mathrm{PM}_{10}$} & SDA & 93 & 124 & 19.1 & 16.4 & 0.2 & 76.5 \\
\hline & & 94 & 153 & 21.2 & 20.0 & 5.4 & 94.0 \\
\hline & SWEPP & 93 & 108 & 18.9 & 17.6 & 0.6 & 48.2 \\
\hline & & 94 & 92 & 19.1 & 18.5 & 8.5 & 33.7 \\
\hline & WERF & 93 & 72 & 19.3 & 17.4 & 2.9 & 56.3 \\
\hline & & 94 & 65 & 22.6 & 22.1 & 1.4 & 70.0 \\
\hline & SWEPP & 93 & 23 & 21.5 & 18.8 & 5.0 & 46.1 \\
\hline & Control & 94 & 23 & 25.6 & 22.9 & 10.7 & 53.0 \\
\hline & WERF & 93 & 22 & 22.2 & 17.8 & 3.6 & 50.9 \\
\hline & Control & 94 & 24 & 25.7 & 27.4 & 4.1 & 50.0 \\
\hline
\end{tabular}

\section{Radioactive Waste Management Complex}

Figure 9 shows the sampling locations of both RESP and SESP air monitors at the RWMC. EG\&G Idaho has measured gross beta activity since 1979. Quarterly averages of RWMC gross beta activity ( $\mathrm{Cs}-137$ equivalent) since 1983 are given in Figure 20. The rise in beta activity in 1986 is attributed to the fallout from the April 1986 Chernobyl accident in the Soviet Union.

Figures 21 and 22 show the gross beta concentration (Cs-137 equivalent) trends at the SDA and SWEPP, respectively, during each semimonthly sampling period during 1994 . The gross beta data have historically followed a seasonal trend that usually increases during the latter part of the year. This same pattern was noted while trending the 1994 data.

Monthly averages of SESP LV air samples at the RWMC for gross beta activity are given in Figure 23. SESP data (monthly averages) and RESP data (quarterly averages shown in Figure 20) show similar trends. 


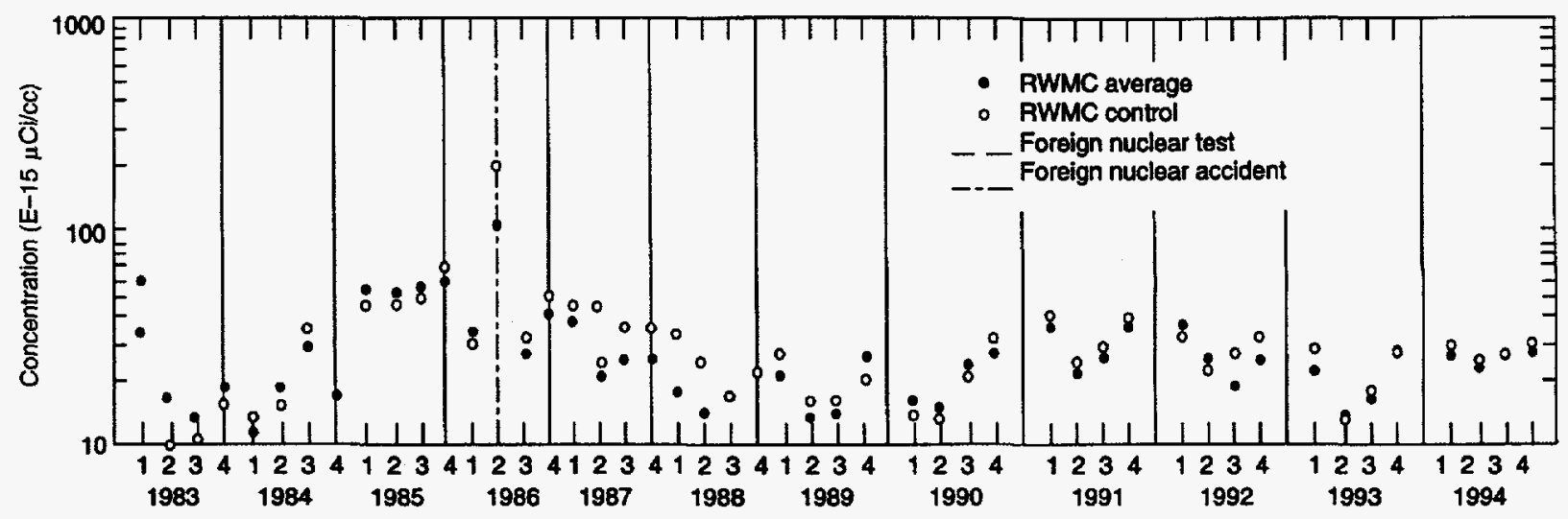

VG95 0280

Figure 20. Quarterly averages of RWMC gross beta air concentrations since 1983.

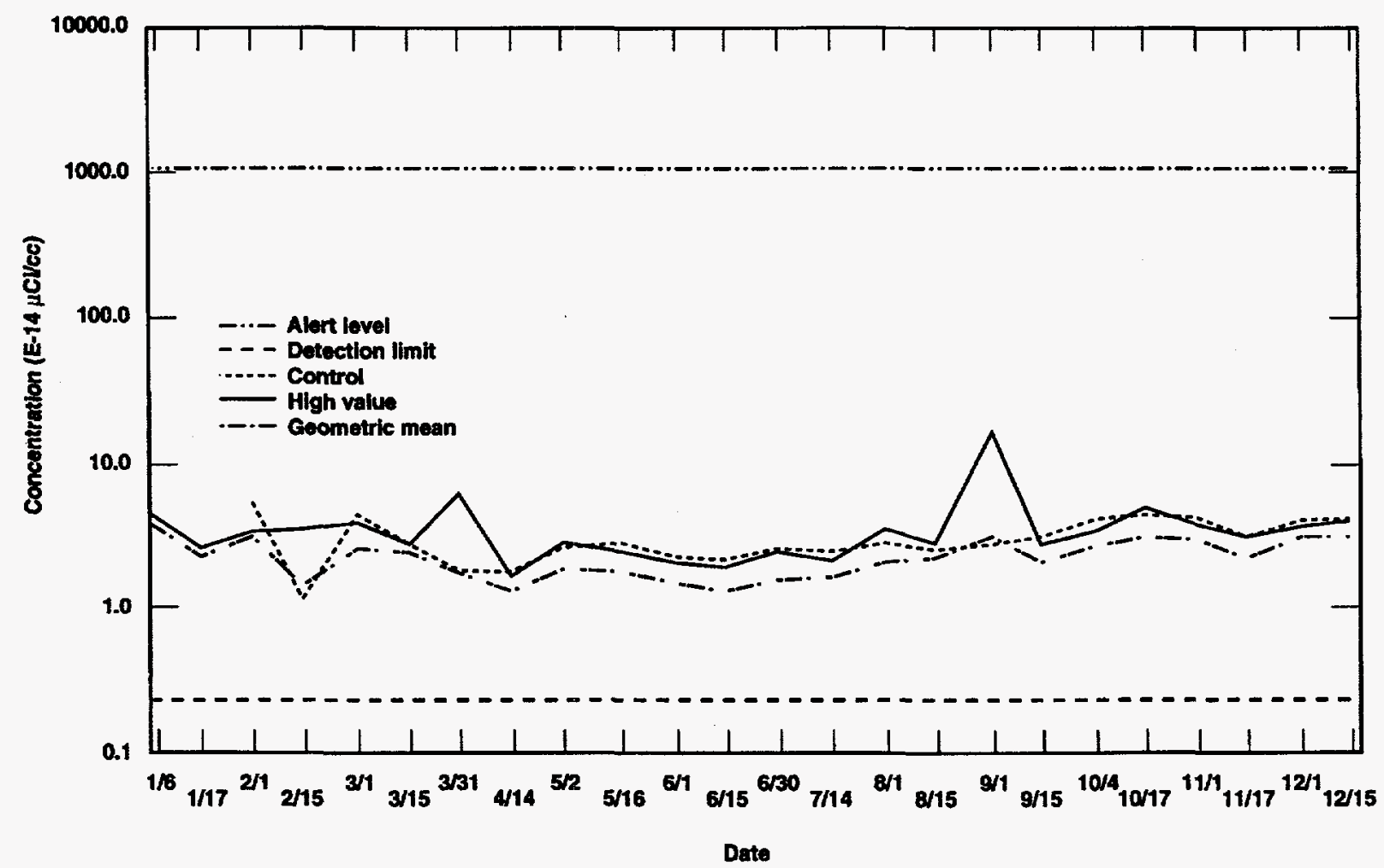

VG95 0287

Figure 21. Gross beta concentration (Cs-137 equivalent) trends for SDA air filters during each semimonthly period of 1994 . 


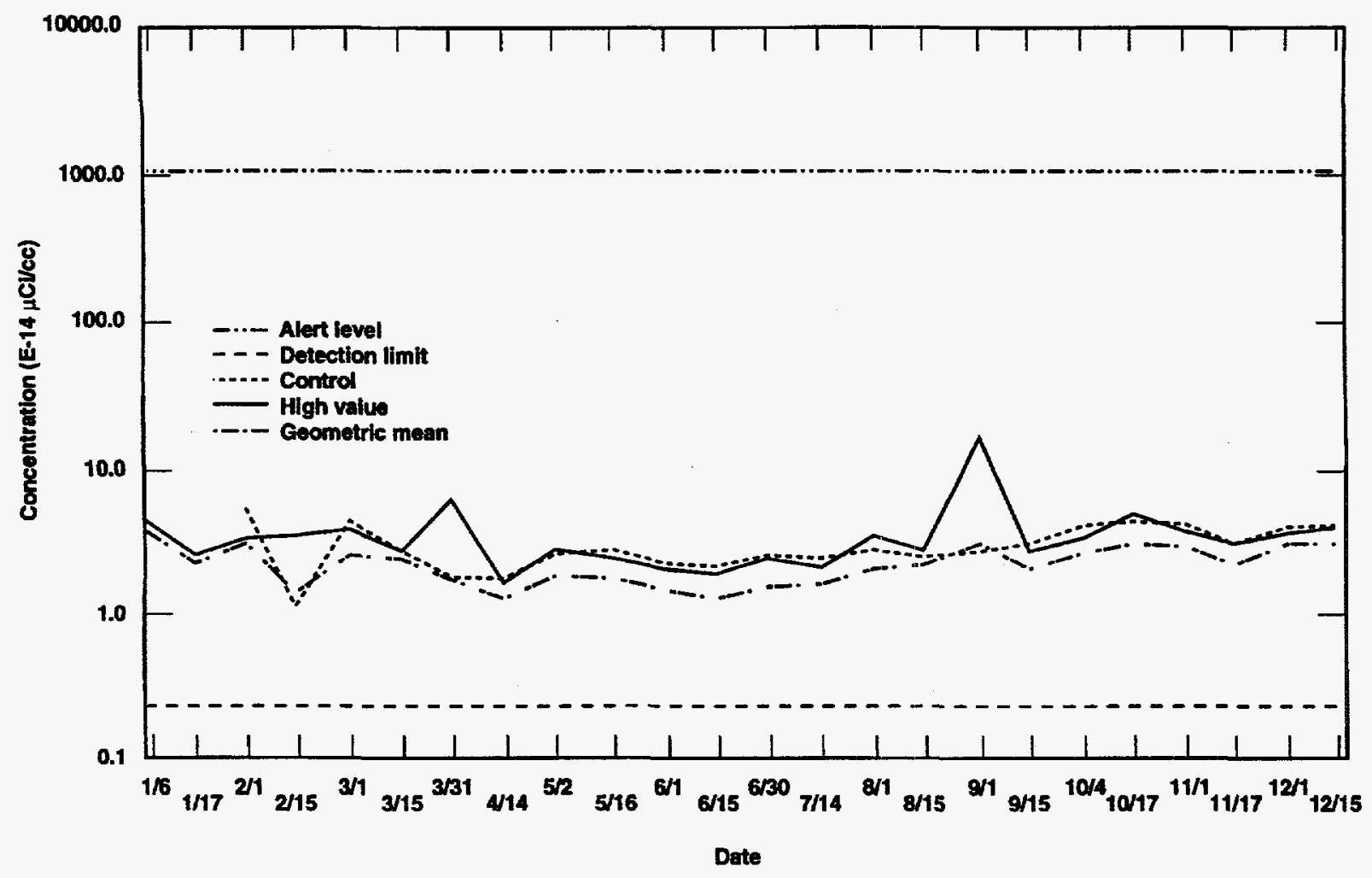

VG95 0287

Figure 22. Gross beta concentration (Cs-137 equivalent) trends for SWEPP air filters during each semimonthly period of 1994 .

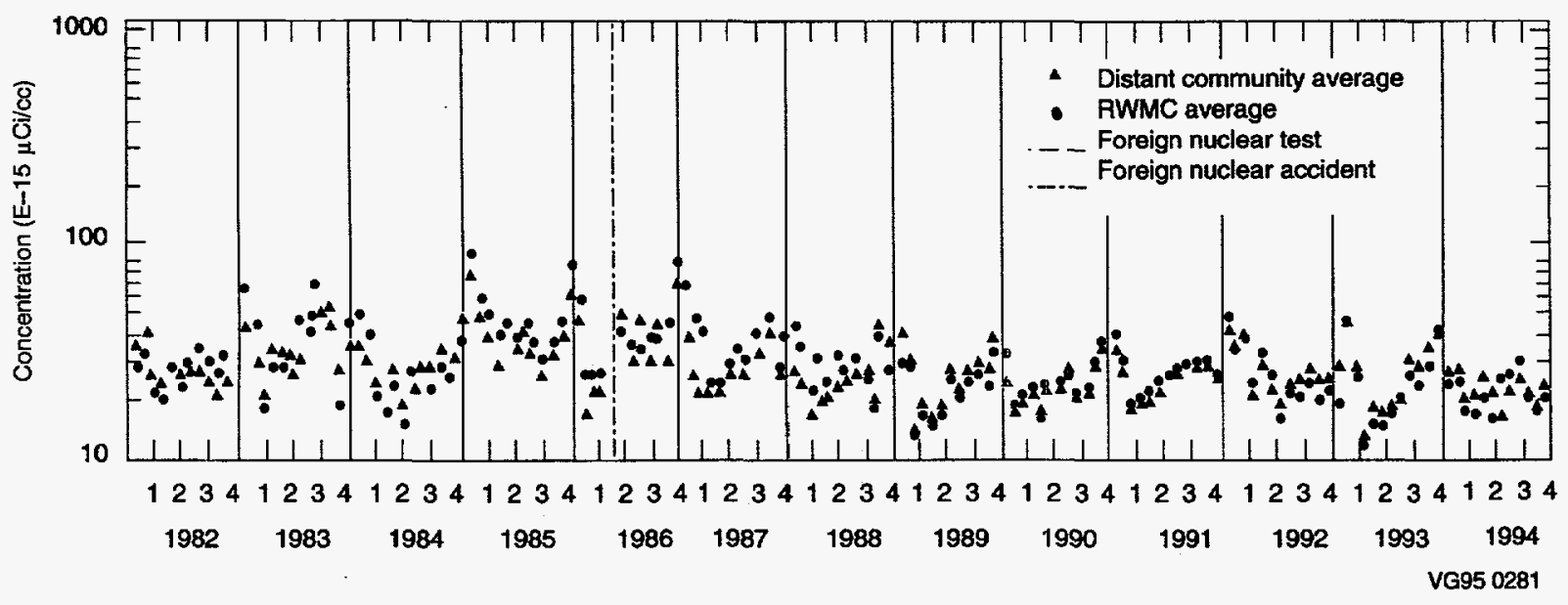

Figure 23. SESP monthly average gross beta concentrations (LV air monitors). 


\section{Analysis for Gamma-Emitting Radio-} nuclides Gamma-emitting radionuclides that could be present due to RWMC operations were not detected in either the RESP or SESP air samples collected at the RWMC in 1994. (Radionuclides most likely to be found at the RWMC and detection limits are listed in Table B-2 of Appendix B.)

\section{Analysis for Specific Alpha- and Beta-} Emitting Radionuclides Only four data points for specific alpha and beta emitters are collected per location in any year, with results frequently less than the detection limit. In general, trend information cannot be developed over a one-year period, nor is it possible to obtain information regarding the time of a release within a one-quarter period. Analysis of quarterly composited air samples provides an indication of the effectiveness of waste confinement. Figure 24 shows a plot of Am-241 and Pu-239,-240 concentrations measured at all RWMC locations since the first quarter of 1986 and their association to the appropriate DCG. In accordance with DOE Order 5400.5, the DCG for Am-241 and $\mathrm{Pu}-239,-240$ is $2.0 \mathrm{E}-14 \mu \mathrm{Ci} / \mathrm{mL}$.

No specific alpha- and beta-emitting radionuclides were detected during the first quarter of 1994. However, during the second quarter, $\mathrm{Sr}-90$ was detected in composite air samples from SWEPP Location 26 (Figure 9). This concentration was $2.5 \pm 0.6 \mathrm{E}-16 \mu \mathrm{Ci} / \mathrm{cc}$ and represents $0.003 \%$ of the DCG for airborne releases of
Sr-90 to the public. This activity indicates a relatively low level of airborne activity. It is also near the lower limit of detection and is below concentrations detected in previous years. $\mathrm{Sr}-\mathbf{9 0}$ has also been detected at or near these levels at control and offsite locations due to dust resuspension.

During the third quarter of $1994, \mathrm{Pu}-239,-240$ was detected in composite air samples from the SWEPP Location 20 (Figure 9). This detection also indicates relatively low levels of airborne activity. This concentration was $8.6 \pm 1.9 \mathrm{E}-18$ $\mu \mathrm{Ci} / \mathrm{cc}$ and represents $0.04 \%$ of the DCG for airborne releases of $\mathrm{Pu}-239,-240$ to the public. This concentration is comparable to concentrations detected in previous years.

\section{Waste Experimental Reduction Facility}

The air monitoring locations around the WERF are shown in Figure 10, and the control location is shown in Figure 11. The quarterly average of gross beta activity for the WERF is shown graphically in Figure 25. The unusually high gross beta results observed in 1986 are attributed to the Chernobyl accident.

Figure 26 shows the maximum gross beta activity concentrations and mean gross beta activity at the WERF for each semimonthly period. Monthly mean concentrations were not statistically different from those reported for the control location.

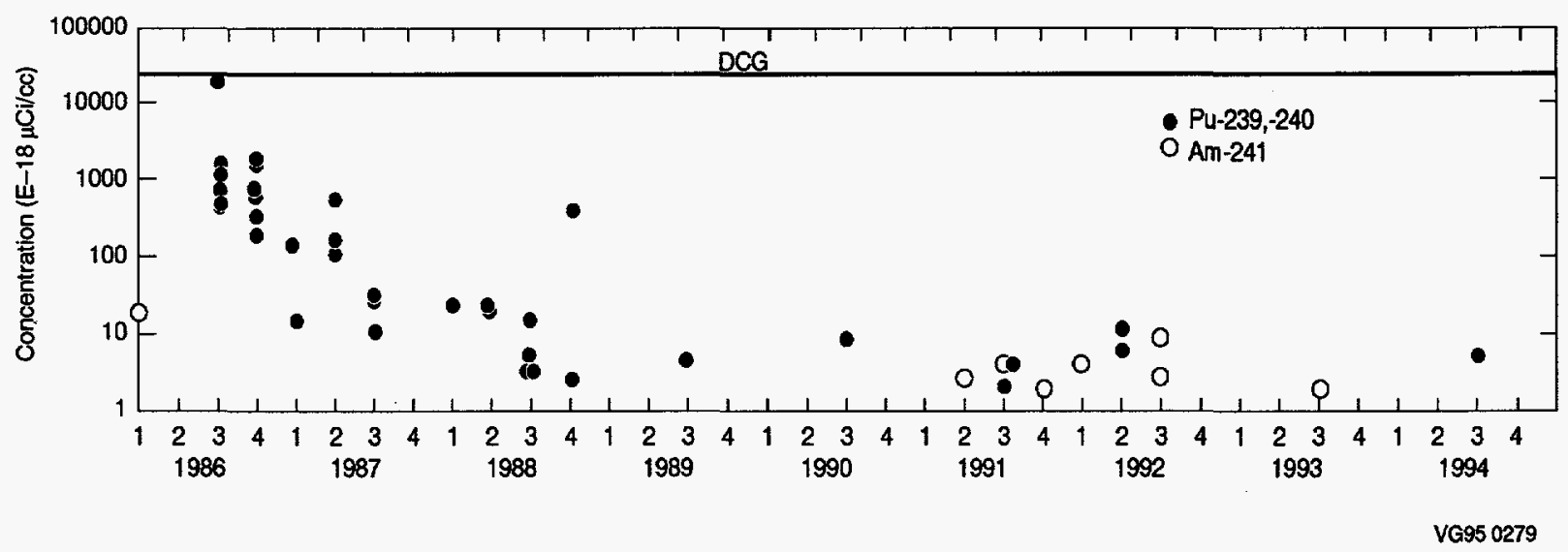

Figure 24. Am-241 and $\mathrm{Pu}-239,-240$ quarterly composite concentrations for air filters at RWMC locations. 


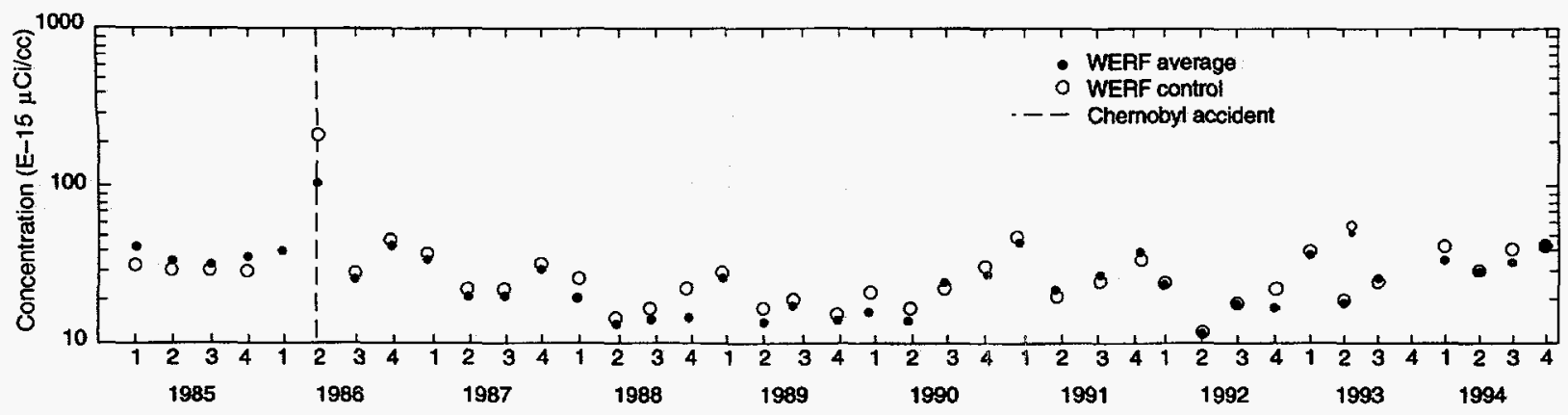

VG95 0278

Figure 25. Quarterly average of gross beta air concentrations measured at WERF.

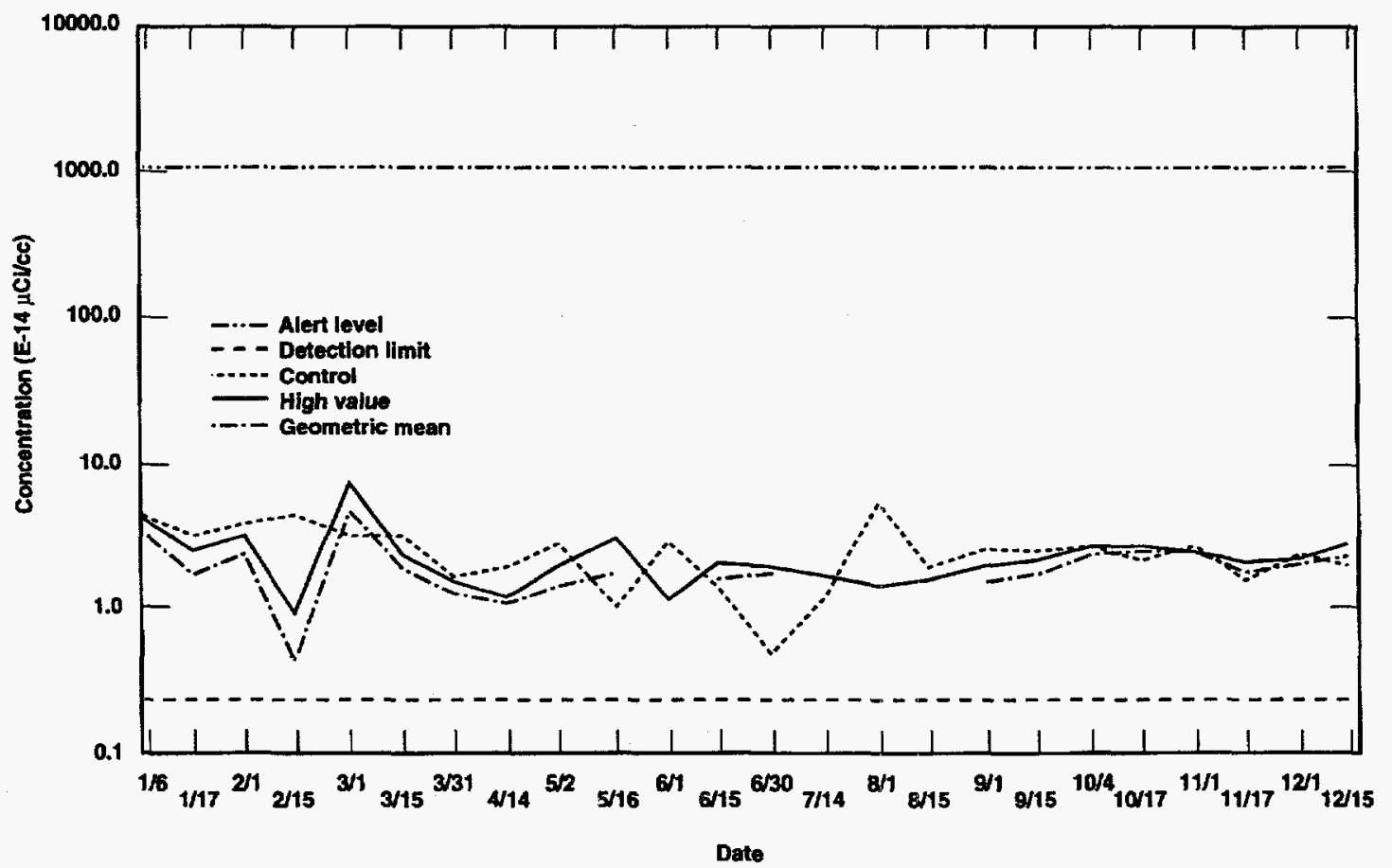

VG95 0286

Figure 26. Maximum gross beta concentrations (Cs-137 equivalent) for WERF air filters during each semimonthly period of 1994 . 
During 1994, there were no detections above background of gamma-emitting radionuclides in WERF monthly air sample composites. Since no known source of TRU radionuclides exists in this area, no specific alpha analyses were performed.

\section{Mixed Waste Storage Facility}

Figure 10 shows the location of the air monitor at the MWSF. This monitor was installed in October 1986. No airborne gross alpha or beta concentrations above ambient levels were detected (see Figure 27). No manmade, gamma-emitting radionuclides were detected at the MWSF during 1994. No specific alpha analyses were performed on any air filters because no known source of TRU radionuclides exists in this area.

\section{Surface Water Run-off}

The specific objectives of the surface water sampling activity are to (a) determine concentrations of radionuclides in any surface waters leaving INEL Waste Management Facilities, (b) report comparisons of measured concentrations against reference levels based on DCGs for the public given in DOE Order 5400.5, and (c) detect and report significant trends in measured concentrations of radionuclides in surface waters leaving INEL Waste Management Facilities.

Each sample was collected in a 4-L polyethylene container and preserved with acid. Filter paper pulp tablets were added, and the container was then sealed, dated, and identified by location. The Radiation Measurements Laboratory (RML) analyzed the samples by means of gamma spectrometry, which was performed on both liquid and particulate fractions. Detection limits for specific radionuclides, including those most likely to be found at the RWMC, are listed in Tables B-1, B-2, and B-3 of Appendix B.

\section{Radioactive Waste Management Com- plex}

Radionuclides could be transported outside the boundaries of the RWMC via surface water runoff. Surface water run-off occurs at the SDA only during periods of snowmelt or heavy precipitation. At these times, water is pumped out of the SDA into a drainage canal. Water also runs off the asphalt pads around TSA and into drainage culverts and the drainage canal, which directs the flow outside the RWMC. The canal also carries outside run $\rightarrow$ off that has been diverted around the RWMC. Ponding of the run-off in a few low areas may increase subsurface saturation, enhancing subsurface migration.

Water samples are collected during each quarter when sufficient rain falls or snow melts to produce run-off water from the TSA asphalt pads and in the SDA gate ditch. One sample is collected from each of the four culverts that drain off of the TSA asphalt pads. These four sampling points are upstream from a drainage ditch. In addition, a sample is taken at the point of discharge from the SDA near the sump pump.

Figure 28 shows the collection of a surface water run-off sample at the RWMC. Surface water run-off draining from the SDA is pumped into the SDA/TSA drainage ditch. Sampling at this point allows a direct assessment of radionuclide migration from the SDA via surface water runoff. Sampling at the TSA-1, TSA-2, TSA-3, and TSA-4 culverts (see Figure 29) allows similar assessments of these areas. Control samples are collected to determine background concentrations of the radionuclides of interest in locations unaffected by facility operations. In 1984, the control sample location was moved from a point on the Big Lost River to a ponding area 1.2 miles north of the RWMC (T-12 Road) because the Big Lost River point was not representative of background surface water run-off at the RWMC. This control location is currently being used with samples collected at the SDA, and a new control location has been established at the rest area on Highway 20 for samples collected at the TSA Pad. 


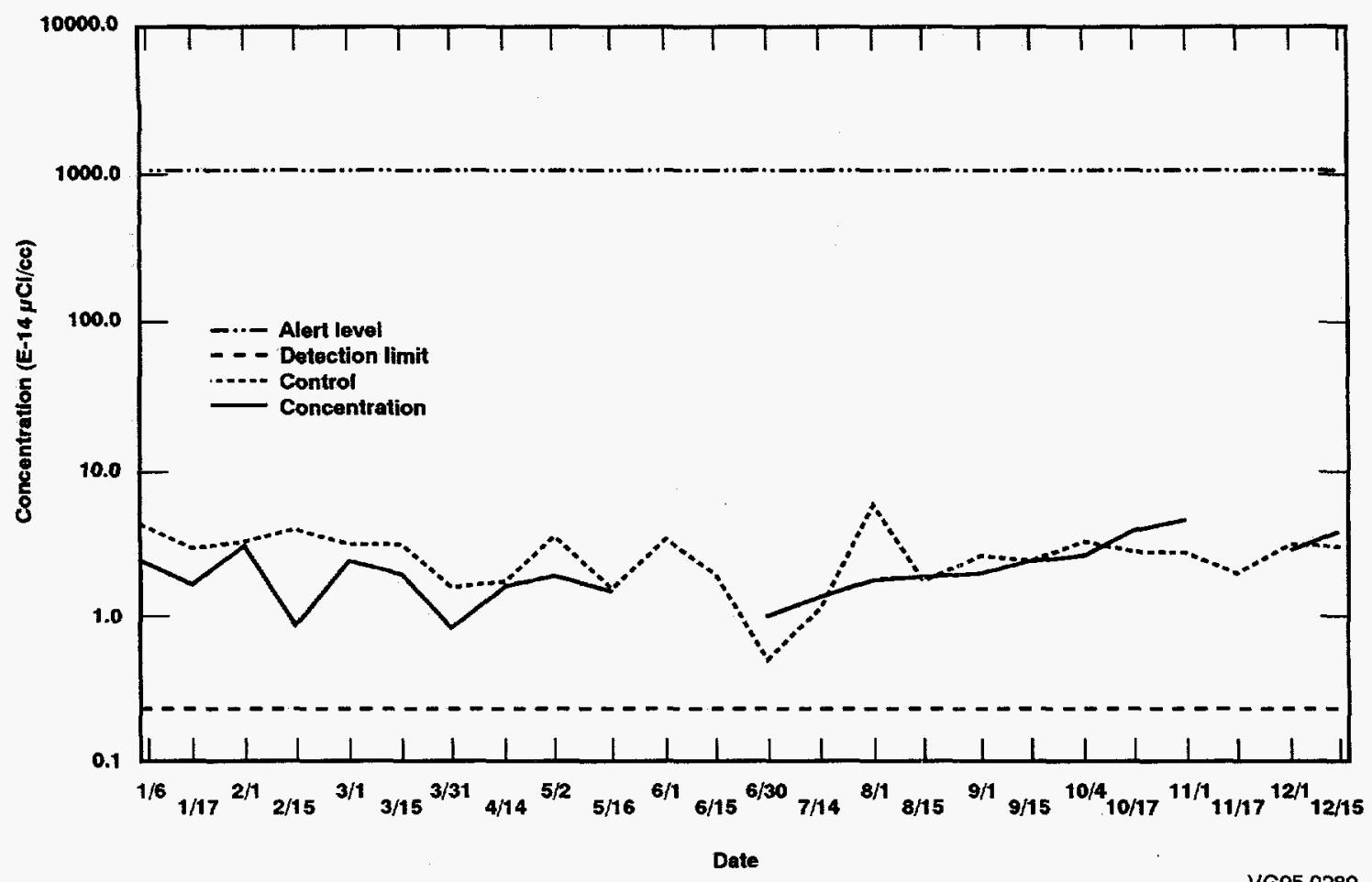

Figure 27. Maximum gross beta concentrations (Cs-137 equivalent) for MWSF air filters during each semimonthly period of 1994.

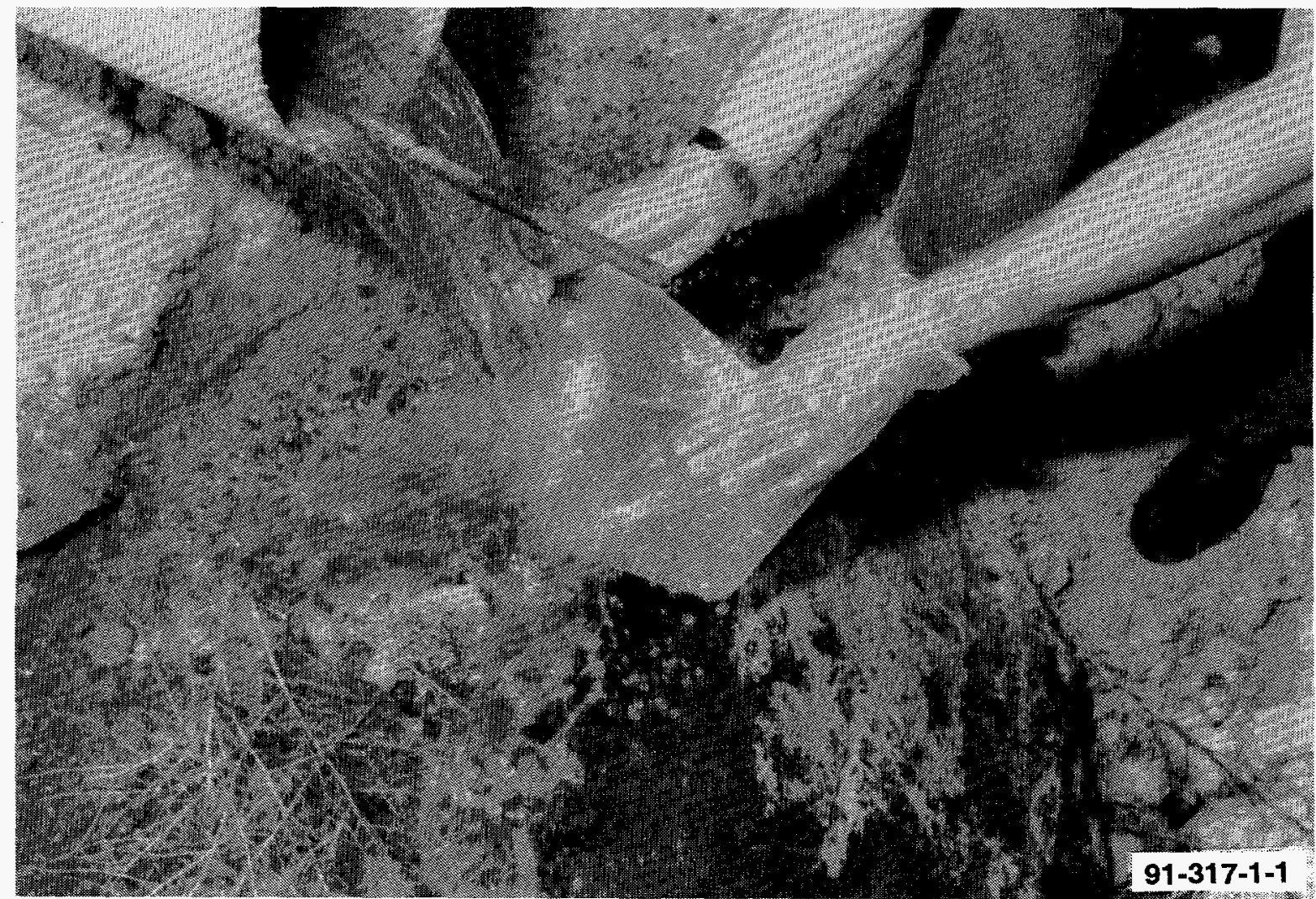

Figure 28. RWMC surface water run-off collection. 


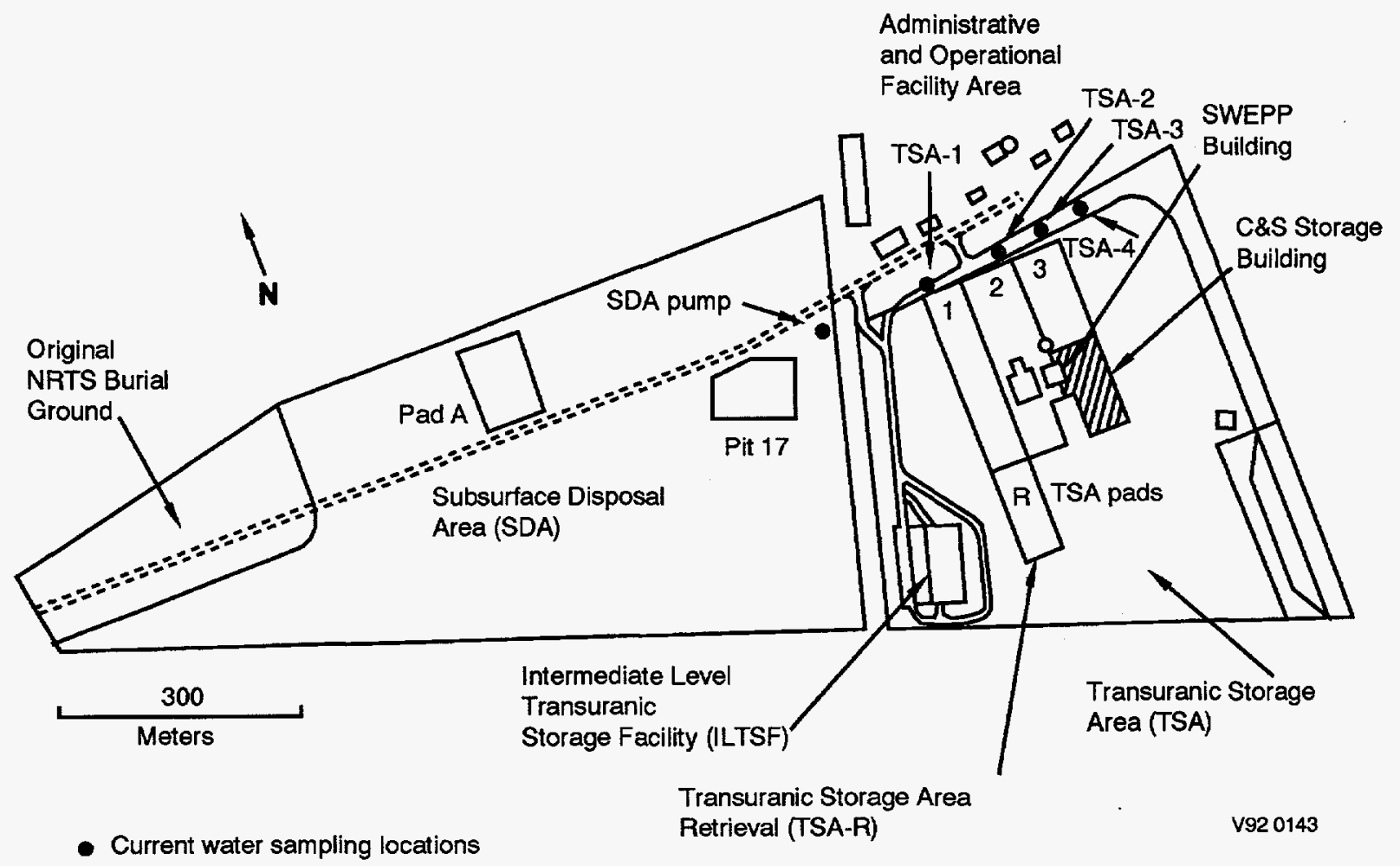

Figure 29. Sampling locations for surface water run-off.

Surface water run-off samples were collected during the first and second quarters of 1994. A sample collected at TSA-1 during the first quarter of 1994 contained $\mathrm{Cs}-137$ in the particulate fraction at a concentration of $9.4 \pm 1.3 \mathrm{E}-10$ $\mu \mathrm{Ci} / \mathrm{mL}$. This was the only manmade, gammaemitting radionuclide detected during 1994. Cs-137 is commonly detected in environmental samples collected at the RWMC, and is usually at or near background levels. This concentration represents $0.03 \%$ of the DCG for water releases of $\mathrm{Cs}-137$ to the public.

Surface water run-off samples were also submitted and analyzed for specific alpha- and betaemitting radionuclides. Am-241 was detected at Location TSA-2 at a concentration of $3.6 \pm 1.1 \mathrm{E}-11 \mu \mathrm{Ci} / \mathrm{mL}$. This concentration represents $0.12 \%$ of the DCG in water. Comparable concentrations of Am-241 have been measured in run-off water at the RWMC in the past. In addition, $\mathrm{Pu}-239,-240$ was also detected at TSA-2. Replicate samples were collected at TSA-2, and three of the four samples showed positive detections for this nuclide. The concentrations ranged from $4.8 \pm 1.3 \mathrm{E}-11 \mu \mathrm{Ci} / \mathrm{mL}$ to $1.1 \pm 0.3 \mathrm{E}-10 \mu \mathrm{Ci} / \mathrm{mL}$. The maximum concentration represents $0.37 \%$ of the DCGs in water. These concentrations are near the detection limits and are comparable to concentrations noted during previous years.

\section{Waste Experimental Reduction Facility}

In the fall of 1994, RESP began collecting surface water run-off samples quarterly at the WERF seepage basins (Figure 30). No samples were collected during the third quarter.

Samples collected during the fourth quarter were submitted for gamma spectrometry. No gamma-emitting radionuclides were detected in these samples. 


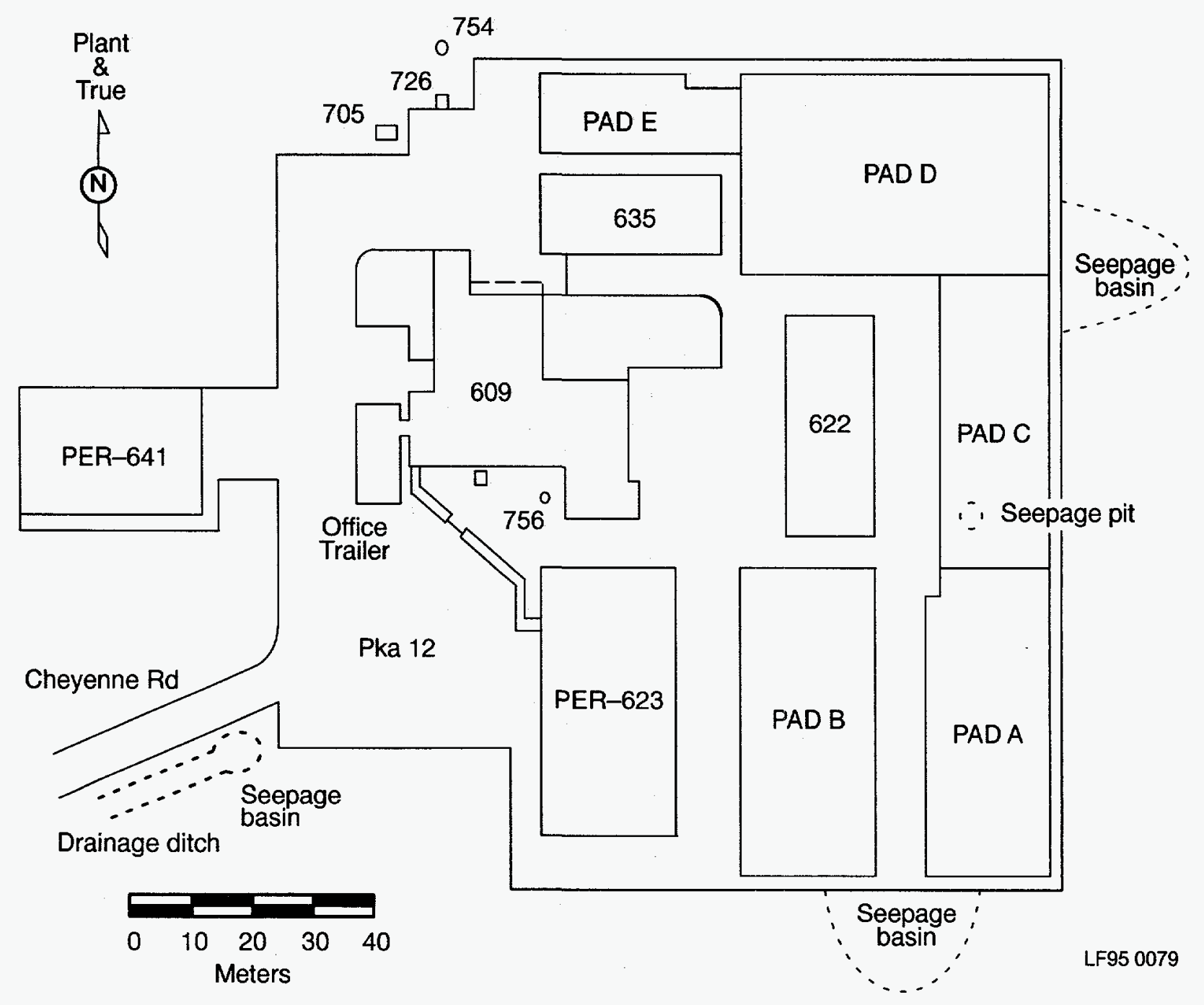

Figure 30. WERF surface water run-off sampling locations. 


\section{Soils}

Soil samples are collected to detect potential changes in soil concentrations caused by surface deposits of airborne contamination and to detect the loss of waste confinement. Measurement of surface deposition over a large area, relative to the area represented by a soil sample, provides a better indication of waste confinement and potential soil contamination.

The specific objectives of the surface soil sampling activity are to determine concentrations of radionuclides in soils in the vicinity of INEL Waste Management Facilities and detect and report significant trends in measured concentrations of radionuclides in soils.

At each sampling station, a soil sample is collected at each of the four corners of a $10 \times 10-\mathrm{m}$ square and at the center of the square. The samples are then combined to form a single composite sample. A stainless-steel sampling ring is used to collect a $12-\mathrm{cm}$ diameter $\times 5-\mathrm{cm}$ deep sample from these soils (see Figure 31 ).

The samples are dried, weighed, homogenized (ball-milled), screened through a number 35 sieve, and then analyzed by gamma spectrometry and radiochemistry. Specific radionuclides that are most likely to be detected and their detection limits are listed in Tables B-1 and B-2 of Appendix B.

\section{Radioactive Waste Management Complex}

Surface and near-surface soils at the RWMC have become contaminated as a result of past flooding of open pits, waste handling, and biotic intrusion. Of particular concern is the presence of $\mathrm{Pu}-239,-240$ and $\mathrm{Am}-241$ deposited in surface soils in and outside the northeast corner of the SDA during flooding events. ${ }^{7}$ Wind, water, and biota can transport contaminated soil particulates onsite and offsite.

The 1983 MAR provides much of the basis for the current surface soil sampling design. ${ }^{14}$ The MAR recommendations were implemented in
1984. The major design modification implemented from the 1983 MAR was to initiate sampling at randomly selected sampling locations in five permanent plots. These plots represent the five major areas of the RWMC, as categorized according to the types of waste buried, current operational activities, and past flooding events. Those major areas are the TSA, Pad A, previously flooded areas, inactive areas, and active areas (see Figure 32).

Although the original sampling areas defined in the 1983 MAR remained consistent, significant changes to the soil sampling activity were recommended by the 1988 MAR committee. ${ }^{15}$ The major proposed revision was to eliminate routine soil sampling and replace it with special studies on an as-needed basis. The rationale for this recommendation was twofold: (a) the number of samples collected are probably insufficient

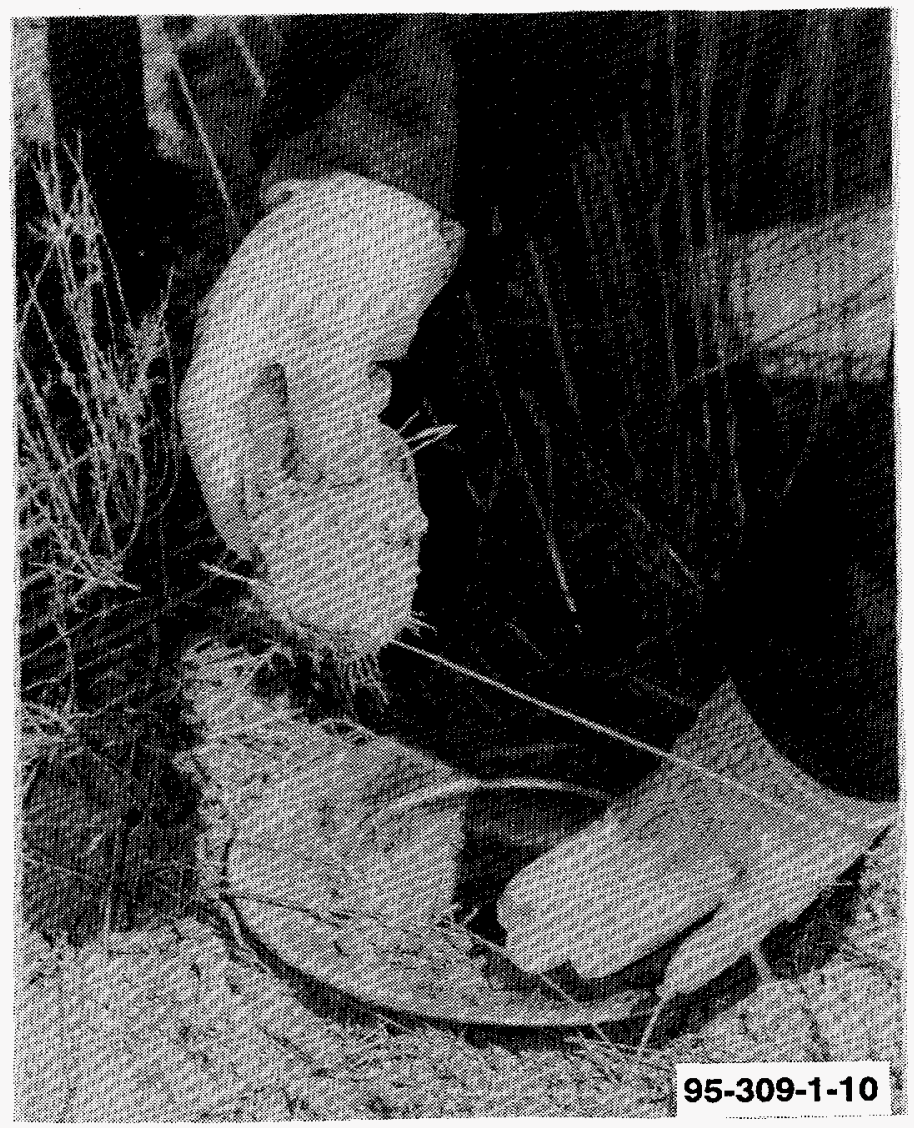

Figure 31. Soil sample collection. 

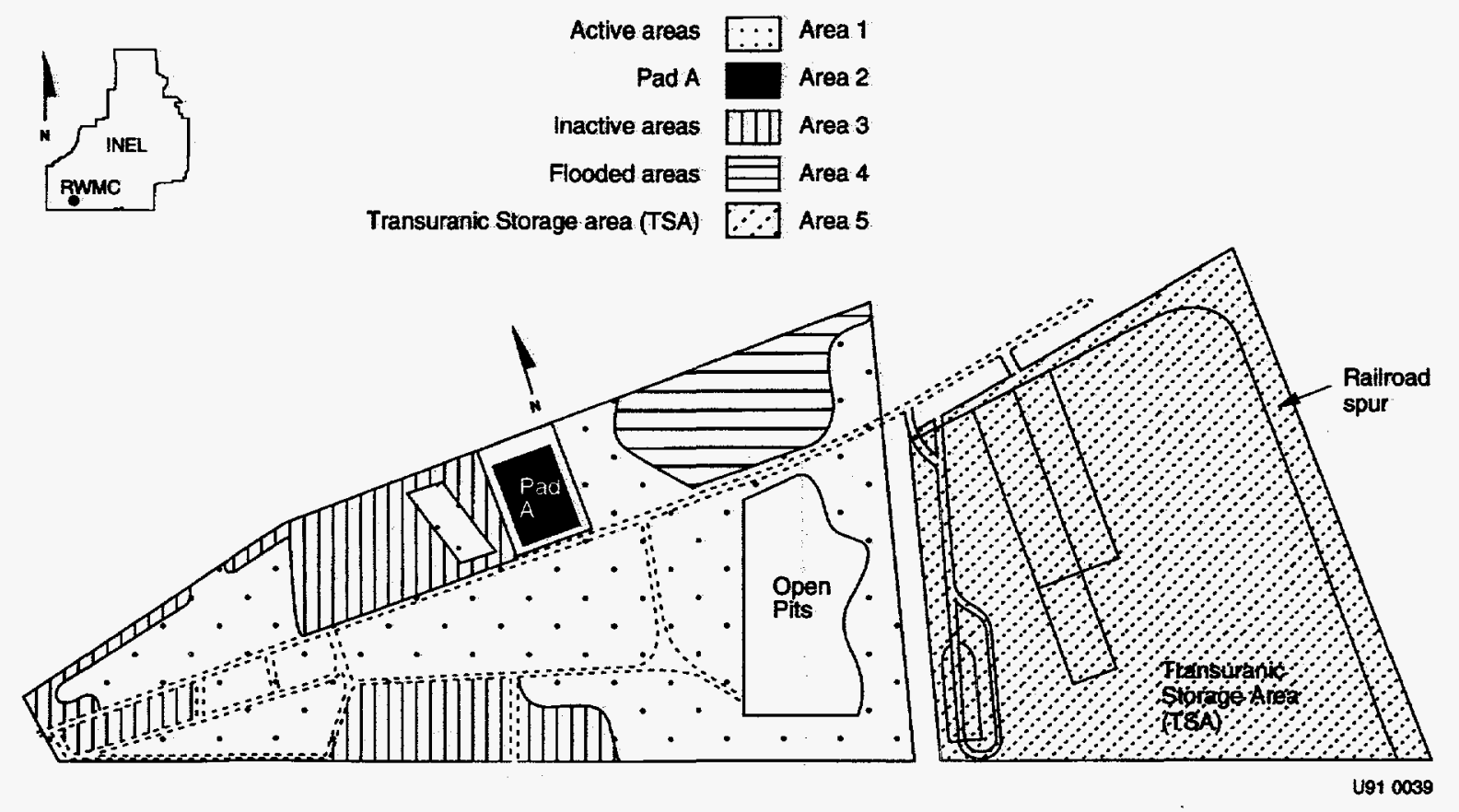

Figure 32. Five major areas of the RWMC used for vegetation, mammal, and soil collection.

for valid data interpretation, and (b) the addition of new soil cover during recontouring of the SDA in 1986 invalidates comparison with past data. RESP began collecting data on the new soil cover on a triennial basis to establish a baseline. This effort began in 1991 at RWMC and in 1992 at SWEPP. While additional soil is still being added to the SDA, RESP will continue to sample every three years to re-establish a baseline for SDA soil concentrations.

The second sample set was collected within the five major areas at the RWMC during 1994. Two gamma-emitting radionuclides (Am-241 and Cs-137) were detected in the RWMC soils. The maximum Cs-137 concentration was $1.02 \pm 0.04 \mathrm{E}-9 \mu \mathrm{Ci} / \mathrm{g}$ and was collected from the TSA.

The TSA and Pad A are the only major areas within the RWMC that have not received additional lakebed soil cover within the last few years. $1994 \mathrm{Cs}-137$ concentrations are consistent with levels found in undisturbed areas in and around the INEL. Concentrations at these levels are most likely attributable to fallout and are not a result of INEL operations.

The maximum concentration of Am-241 by gamma spectroscopy was $3.2 \pm 0.2 \mathrm{E}-9 \mu \mathrm{Ci} / \mathrm{g}$ and was collected from the previously flooded areas. Selected samples from each of the five major areas at the RWMC were analyzed for specific alpha- and beta-emitting radionuclides.

Results of analyses for specific alpha- and beta-emitting nuclides are shown in Table 4. Table 4 shows only those concentrations considered above the level of detection. Activities for $\mathrm{Sr}-90$, $\mathrm{Pu}-239,-240$, and Am-241 were detected in all major areas of the RWMC. With the exception of $\mathrm{Pad} \mathrm{A}$ and TSA, recontouring efforts have generally decreased the concentrations. As shown in Table 4, samples from Pad A yields the maximum 
Table 4. Specific radionuclide results for RWMC soils.

Concentration $(\mu \mathrm{Ci} / \mathrm{g})$

\begin{tabular}{|c|c|c|c|c|}
\hline Location & $\mathrm{Sr}-90$ & $\mathrm{Pu}-238$ & $\mathrm{Pu}-239,-240$ & $\overline{A m-241}$ \\
\hline \multirow[t]{2}{*}{ Active Area } & $6.3 \pm 1.1 \mathrm{E}-7$ & & $5.5 \pm 0.9 \mathrm{E}-8$ & $1.1 \pm 0.2 \mathrm{E}$ \\
\hline & $1.1 \pm 0.2 \mathrm{E}-6$ & & $9 \pm 3 \mathrm{E}-9$ & $2.2 \pm 0.4 \mathrm{E}$ \\
\hline \multirow[t]{2}{*}{ Pad A } & $8.0 \pm 1.3 \mathrm{E}-7$ & $1.9 \pm 0.4 \mathrm{E}-8$ & $1.2 \pm 0.1 \mathrm{E}-6$ & $1.6 \pm 0.2 \mathrm{E}$ \\
\hline & $1.32 \pm 0.2 \mathrm{E}-6$ & & $3.7 \pm 0.6 \mathrm{E}-8$ & $9.0 \pm 1.1 \mathrm{E}$ \\
\hline Inactive Area & $5.8 \pm 1.1 \mathrm{E}-7$ & & $4.5 \pm 0.8 \mathrm{E}-8$ & $1.4 \pm 0.4 \mathrm{E}$ \\
\hline Flooded Areas & $4.1 \pm 1.0 \mathrm{E}-7$ & $1.4 \pm 0.3 \mathrm{E}-8$ & $7.2 \pm 0.7 \mathrm{E}-7$ & $1.3 \pm 0.2 \mathrm{E}$ \\
\hline \multirow[t]{2}{*}{ TSA } & $8.2 \pm 1.3 \mathrm{E}-7$ & $5.1 \pm 1.4 \mathrm{E}-9$ & $1.8 \pm 0.2 \mathrm{E}-7$ & $5.0 \pm 0.5 \mathrm{E}$ \\
\hline & $8.5 \pm 1.4 \mathrm{E}-7$ & & $2.8 \pm 0.5 \mathrm{E}-8$ & $3.8 \pm 0.8 \mathrm{E}$ \\
\hline Control & $6.4 \pm 1.2 \mathrm{E}-7$ & & & \\
\hline ECG* & $6.0 \mathrm{E}-6$ & $8.0 \mathrm{E}-5$ & $8.0 \mathrm{E}-5$ & $4.0 \mathrm{E}-5$ \\
\hline $\begin{array}{l}\% \text { of ECG for } \\
\text { maximum } \\
\text { concentration }\end{array}$ & 22.0 & 0.02 & 1.5 & 4.0 \\
\hline
\end{tabular}

* $\quad E C G=$ Environmental Concentration Guidelines. These concentrations correspond to a 50-year dose commitment of $100 \mathrm{mrem} / \mathrm{yr}$ to a homesteader beginning in the first year after release of the facility. This concentration assumes uniform contamination of an area adequate for subsistence farming. 
concentrations for all the radionuclides. These concentrations are considerably less than the environmental concentration guide-lines (see Table 4) that are calculated to correspond to a 50 -year dose commitment of $100 \mathrm{mrem} / \mathrm{yr}$ to a homesteader beginning in the first year after release from the facility. This concentration assumes uniform contamination of an area adequate for subsistance farming. These concentrations are comparable to historical data.

\section{Waste Experimental Reduction Facility}

When routine soil samples are collected from the WERF area, collection occurs at the 11 locations shown in Figure 33. Control samples are collected near the Main Gate, Building 603 (see Figure 11). No samples were collected during 1994. The next scheduled sample collection is in the summer of 1996.

\section{Biotic Surveillance}

Plants and animals are potential pathways for migration of radionuclides away from facilities at which radioactive contaminated wastes are stored. Several studies done previously by RESL and currently by ESRF have indicated that small burrowing mammals, such as deer mice, transport radionuclides. ${ }^{16}$ Uptake of radionuclides by vegetation at the RWMC has also been documented by RESL. ${ }^{17}$

Routine biotic monitoring was not conducted prior to 1983 . Some preliminary data on radionuclide concentrations in deer mice and crested wheatgrass were collected by EG\&G Idaho during fiscal year 1982. Visual biotic inspections began in April 1983.

A detailed long-range plan for biotic monitoring, including procedures for routine monitoring, was completed in the fall of 1983.18 The sampling design involved sampling at the five major areas designated for soil sampling.

The specific objectives of the routine biotic surveillance are to (a) determine if biota are transporting radionuclides from buried waste or contaminated soil, (b) identify biotic conditions which may compromise waste confinement at waste storage and disposal facilities, and (c) detect and report significant trends in radionuclide concentrations in biotic samples.

\section{Vegetation}

Three subsamples are collected from each of the sampling locations and combined into one composite sample. The method of collection and species alternates each year. Crested wheatgrass is collected in odd-numbered years and is clipped at ground level within a $1 \times 1-\mathrm{m}$ frame. Russian thistle is collected in even-numbered years, and the entire plant is pulled up within a $1 \times 1-m$ frame (see Figure 34). Either rabbitbrush or sagebrush is collected in odd-numbered years by clipping $20 \%$ of the branches from the designated plants. Thus, the same plant can be sampled biennially.

The samples are oven-dried, milled, and weighed before they are submitted to the RML for gamma spectrometry analyses. Based on gamma analyses, selected samples are submitted to the Radiation and Environmental Measurement Systems for specific alpha and beta analyses.

Prior to 1990, RESP performed specific radiochemical analysis only if gamma spectrometry indicated the presence of Am-241. If Am-241 was not detected in any sample, then one sample from the previously flooded area of SDA was submitted for this analysis. In 1990, RESP concluded that this practice was restricting the accumulation of an adequate baseline of such data, against which comparisons could be made in future years. The program subsequently began submitting at least one sample from each of the five major areas for radiochemical analysis annually. The accumulated results of this sampling are eventually expected to provide an adequate basis for comparison of future data against baseline conditions for each area. 


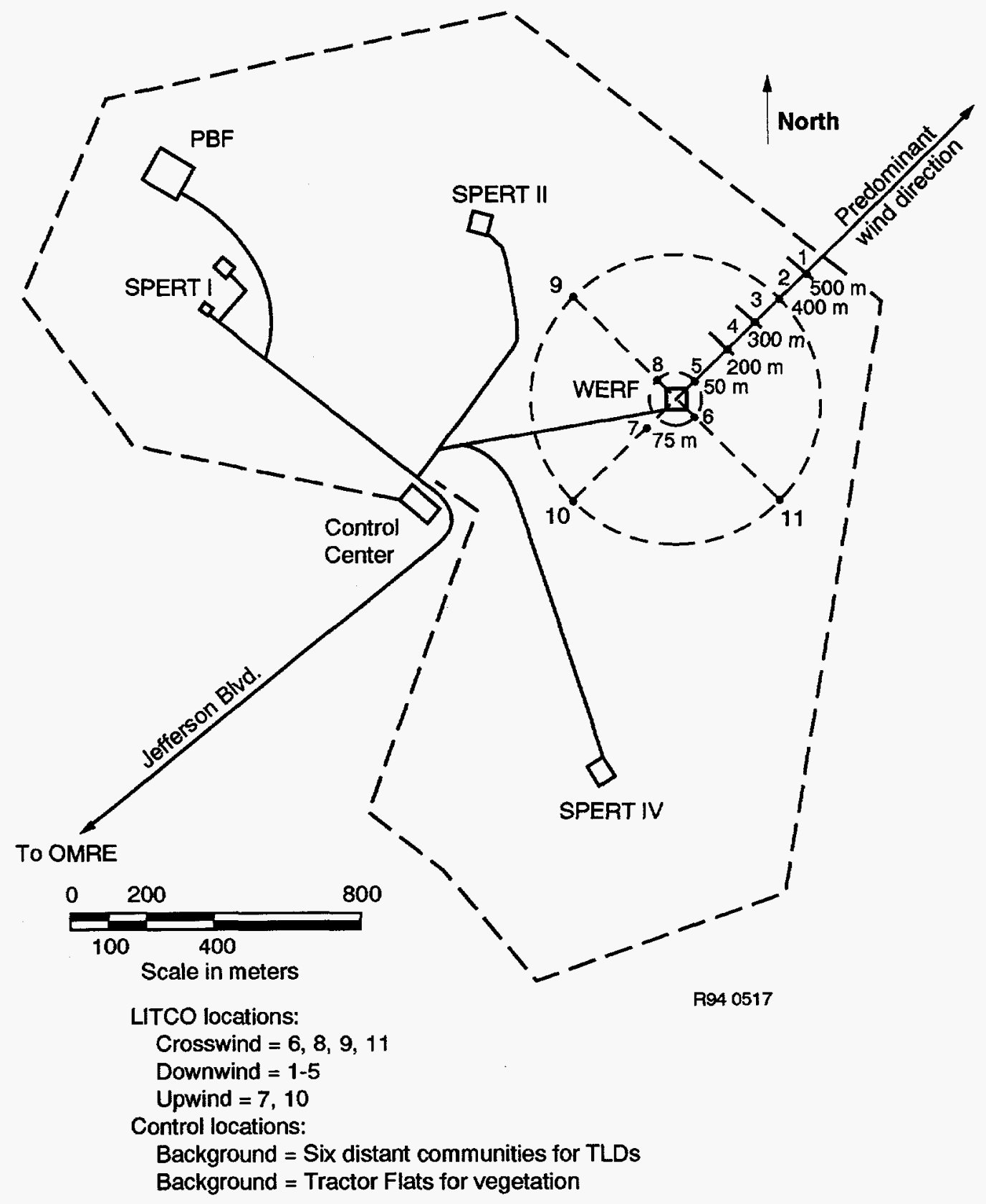

Figure 33. WERF TLD soil and vegetation locations. 


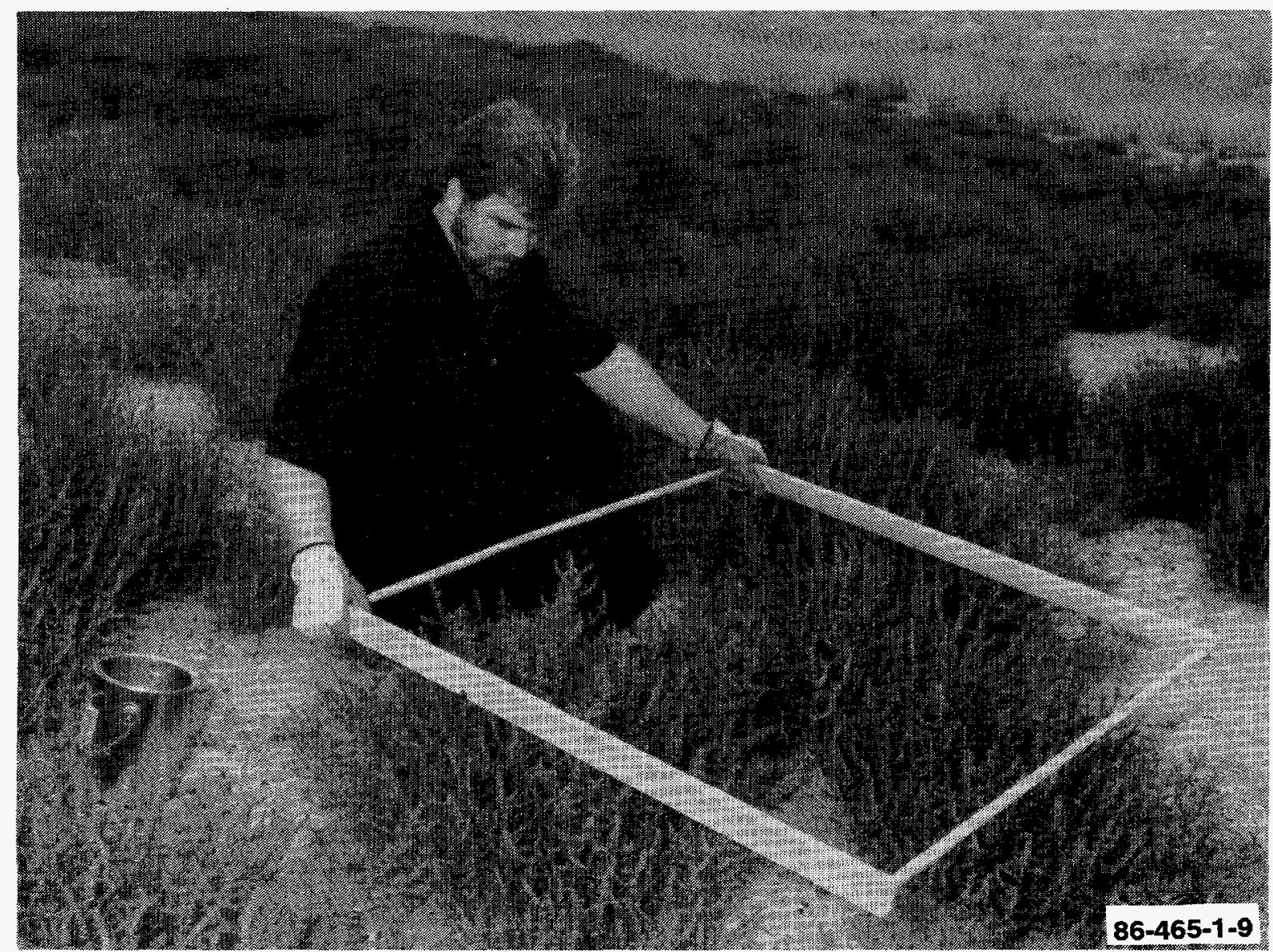

Figure 34. Vegetation collection at the RWMC.

RWMC. Russian thistle was scheduled to be collected in 1994 from five major areas of the RWMC (see Figure 32). However, due to increased operational activity and the disturbance of the ground cover in and around the RWMC, representative samples could not be obtained; thus, no samples were collected during 1994.

WERF Vegetation collection at WERF began in 1984 and is performed every three years. The next sagebrush samples are scheduled to be collected in 1996 (see Figure 33).

\section{Radioactivity in Small Mammals}

The RESP has routinely sampled small mammals at the RWMC to evaluate confinement integrity of buried waste. The species for collection, as well as the method of collection, alter- nates each year. Deer mice are collected in odd-numbered years, and ground squirrels are collected in even-numbered years. Recently, the population of the small mammals has decreased to a point where it is not possible to ensure collection of a representative sample. The declining population is due to increasing operational activity and disturbance of ground cover in and around RWMC.

\section{Soil Excavated by Small Mammals}

Samples of soil excavated by burrowing animals had been scheduled to be collected during 1994 at the RWMC from each of the five major areas (see Figure 32). No samples were collected due to recontouring activities and due to the diminishing population of small mammals at the facility. 


\section{Penetrating Radiation}

TLDs are used to measure cumulative exposures to ambient ionizing radiation. Figure 35 shows the placement of a TLD.

TLDs are sensitive to beta energies greater than $200 \mathrm{KeV}$ and to gamma energies greater than $10 \mathrm{KeV}$. The TLD packets contain five lithium fluoride chips and are located about $1 \mathrm{~m}$ above the ground at specified locations. The five chips provide replicate measurements at each location. The TLD packets are replaced in May and November of each year. The sampling periods for 1994 were from November 1993 to May 1994, and from May to November 1994.

The specific objectives of the penetrating radiation monitoring activity are to (a) demonstrate compliance with the limit for direct penetrating radiation established in RWMC Project Directive 6.1, "Radiation and Contamination Control"19 (1 mR/hr at $3 \mathrm{ft}$ above ground), (b) characterize direct radiation levels at specific points of interest at INEL Waste Management Facilities, and (c) detect and report significant trends in measured levels of penetrating radiation.

\section{Trend Analysis}

TLD cumulative 6-month exposure data for 1986 through 1994 from SDA, TSA, and WERF are presented in Figure 36. Data from the distant communities are excluded from the trend chart. To provide an indication of the general trend in values over time, data in the graph were smoothed using negative exponential smoothing. The data are plotted on a logarithmic scale to give a clearer picture of the trends. Although there has been some cycling of values, the general trend in the graph indicates a gradual decline in TLD exposures over time. However, the 1994 data indicate an increase over 1993 data (see facility discussions for details).

\section{Comparisons by Facility}

A table of summary statistics (e.g. means, medians, maximum, and minimum values) for
1994 TLD exposures are given in Table 5. Additionally, Box and Whisker plots of the TLD exposure by facility (including the distant communities) are provided for both 1993 and 1994 (Figures 37 and 38). The 1993 TLD exposures are included to provide an indication of short term changes in levels.

The median 1994 exposure values for the distant communities and for all of the facility groupings increased from the median exposure values calculated for 1993. The Kruskal-Wallis test for differences in medians indicated that the changes from 1993 to 1994 were statistically significant (at the .05 level) for the distant communities, as well as at all of the site facility groupings.

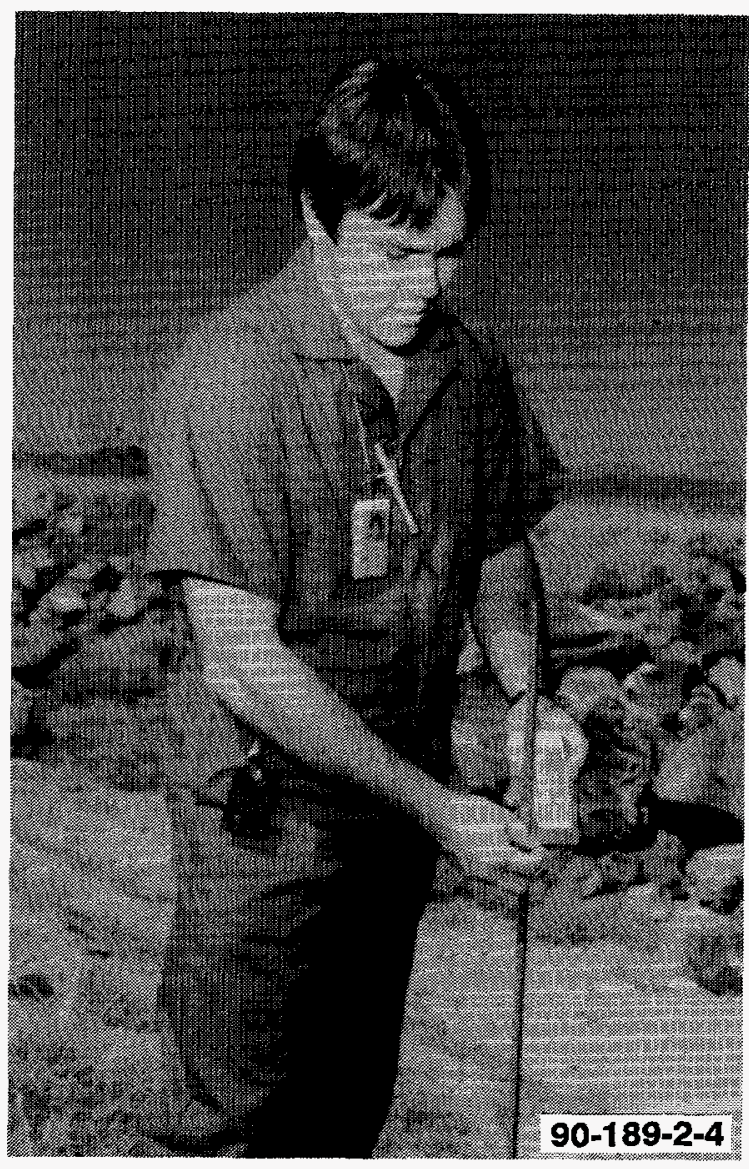

Figure 35. Placement of a TLD at a facility perimeter station. 


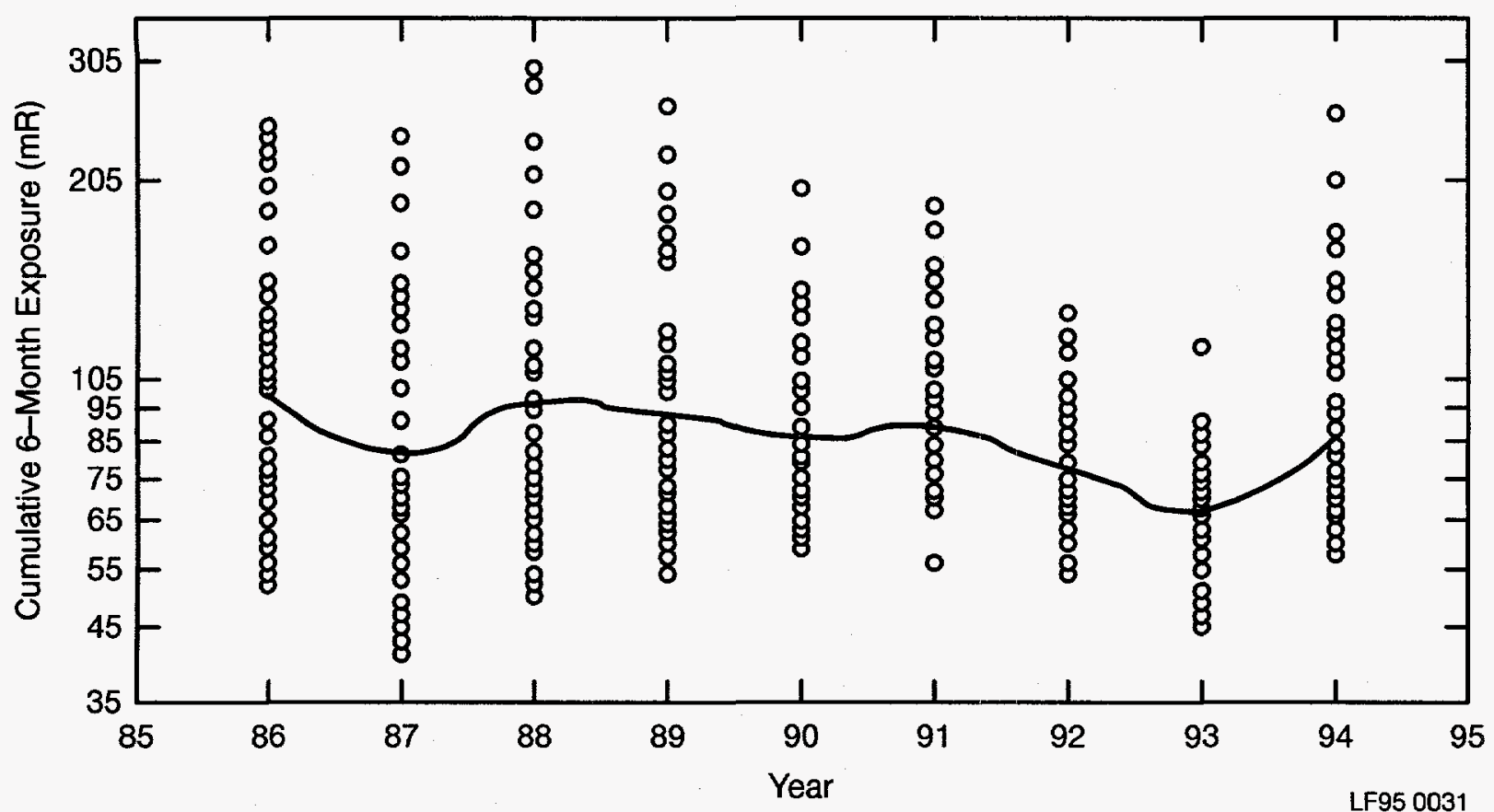

Figure 36. TLD exposure data from SDA, TSA, and WERF using negative exponential smoothing.

Table 5. Summary statistics for 1994 TLD 6-month exposures (all concentration values are mR).

\begin{tabular}{|c|c|c|c|c|c|c|}
\hline Facility & Season & $\mathrm{N}$ & Mean & Median & Minimum & Maximum \\
\hline \multirow[t]{2}{*}{ SDA } & Spring & 19 & 83.1 & 77.0 & 60 & 140 \\
\hline & Fall & 18 & 121.1 & 114.5 & 58 & 256 \\
\hline \multirow[t]{2}{*}{ TSA } & Spring & 12 & 74.3 & 71.5 & 66 & 97 \\
\hline & Fall & 11 & 88.5 & 89.0 & 72 & 118 \\
\hline \multirow[t]{2}{*}{ WERF } & Spring & 11 & 71.8 & 67.0 & 63 & 85 \\
\hline & Fall & 11 & 68.1 & 66.0 & 58 & 81 \\
\hline \multirow{2}{*}{$\begin{array}{l}\text { Distant } \\
\text { Communities }\end{array}$} & Spring & 7 & 64.6 & 63.0 & 60 & 71 \\
\hline & Fall & 6 & 61.2 & 61.0 & 56 & 70 \\
\hline
\end{tabular}




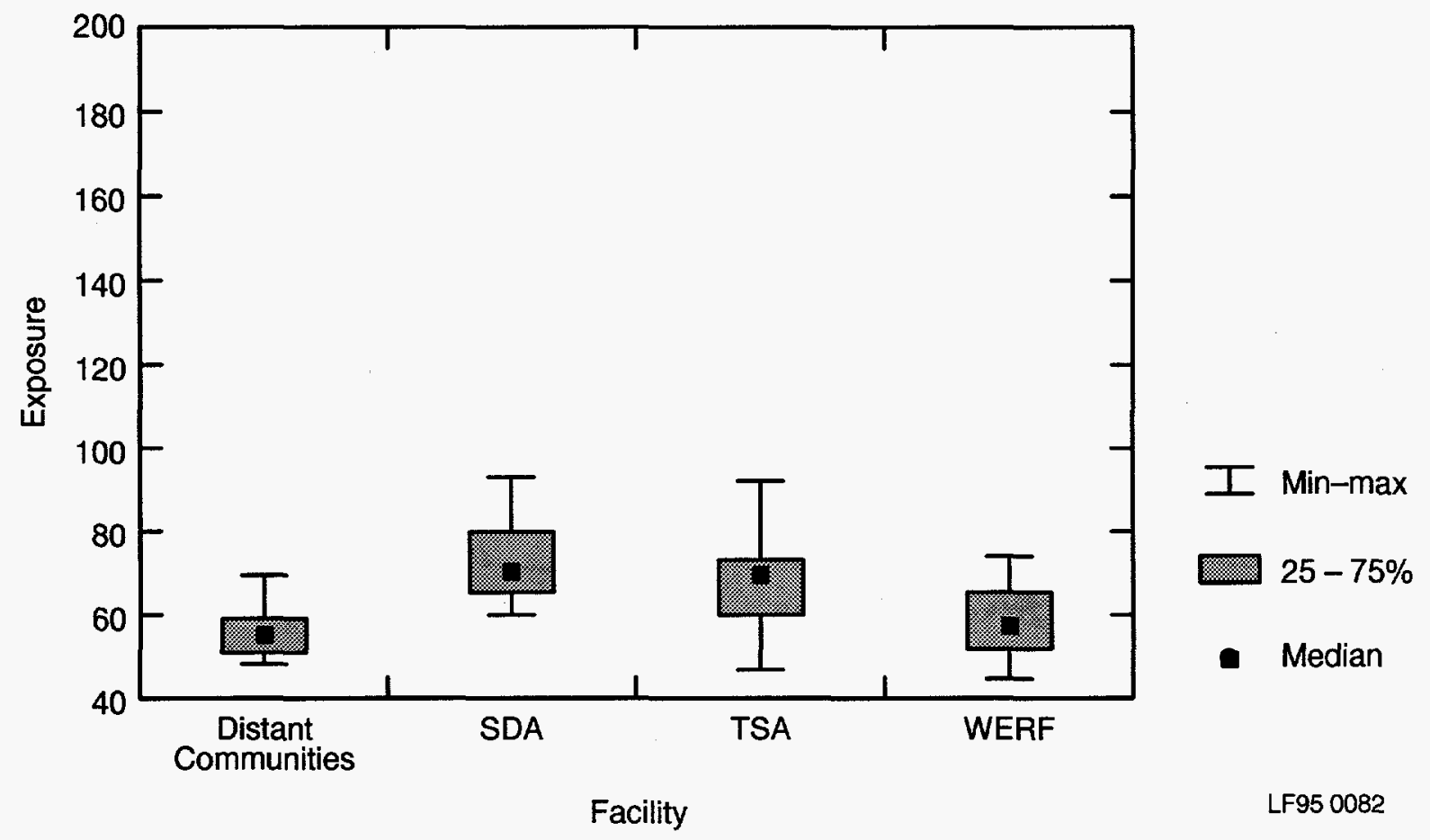

Figure 37. 1993 Box and Whisker plots of the TLD exposure by facility.

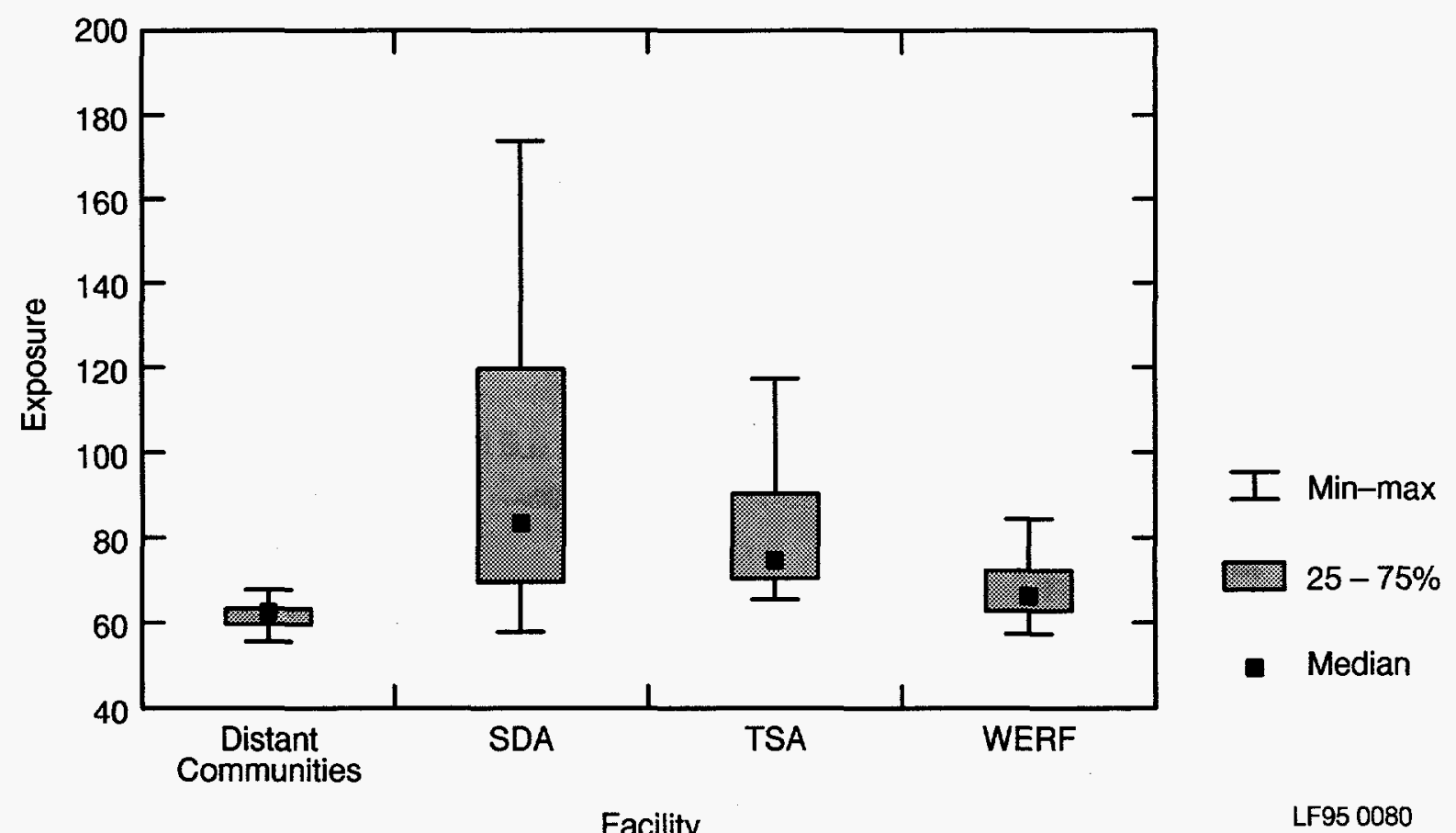

Figure 38. 1994 Box and Whisker plots of the TLD exposure by facility. 


\section{Seasonal Change}

The Box and Whisker plot of the 1994 TLD exposure data by season (including all facilities and the distant communities) indicates that the median exposure value for the fall measurement period ending in November of 1994 was slightly greater than that of the spring measurement period ending in May of 1994 (see Figure 39). However, the difference (tested using the Kruskal-Wallis test) was found not to be statistically significant (at the .05 level).

\section{Radioactive Waste Management Complex}

RESP placed TLD packets at five locations around the RWMC and at two locations on the TSA fence. TLD packets were placed at 24 other locations by SESP. (See Figure 40 for all locations). The locations at Stations 1, 31, 33, and 35 were changed slightly in November 1988 and are now labeled 1B, 31B, 33B, and 35B. SESP Locations 3A through 31A were moved in May 1988 because a new fence was installed and the dike was raised around the SDA. Two additional locations, Stations 46 and 47 , were added to the perimeter of the RWMC in May 1989, and thus, a total of 31 locations were monitored.

Background exposure results from penetrating radiation from natural terrestrial sources (rocks and soil), cosmic radiation, fallout from testing of nuclear weapons, and local industrial processes. The background exposures used in this report are the averages of exposures measured by TLDs in the seven communities on the Snake River Plain located outside the INEL boundary. Background exposures were measured at Aberdeen, Blackfoot, Craters of the Moon National Monument, Idaho Falls, Minidoka, Rexburg, and Roberts.

Station 33B showed the highest exposure in the first reporting period of 1994, and Station 35B showed the highest exposure during the second period of 1994 . These stations measure exposures associated with the active disposal pit

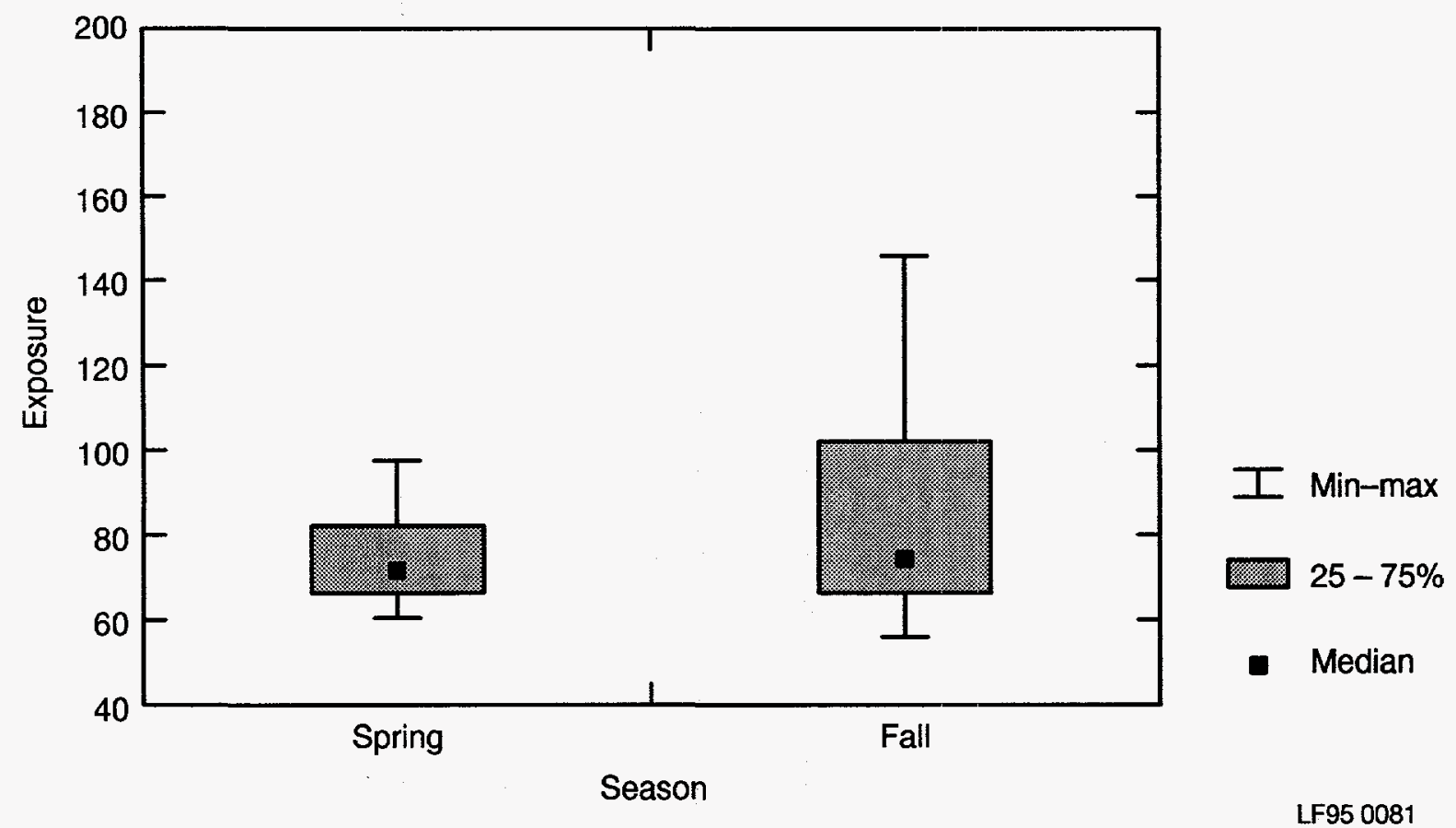

Figure 39. Exposure trends for the spring and fall average TLD measurements. 


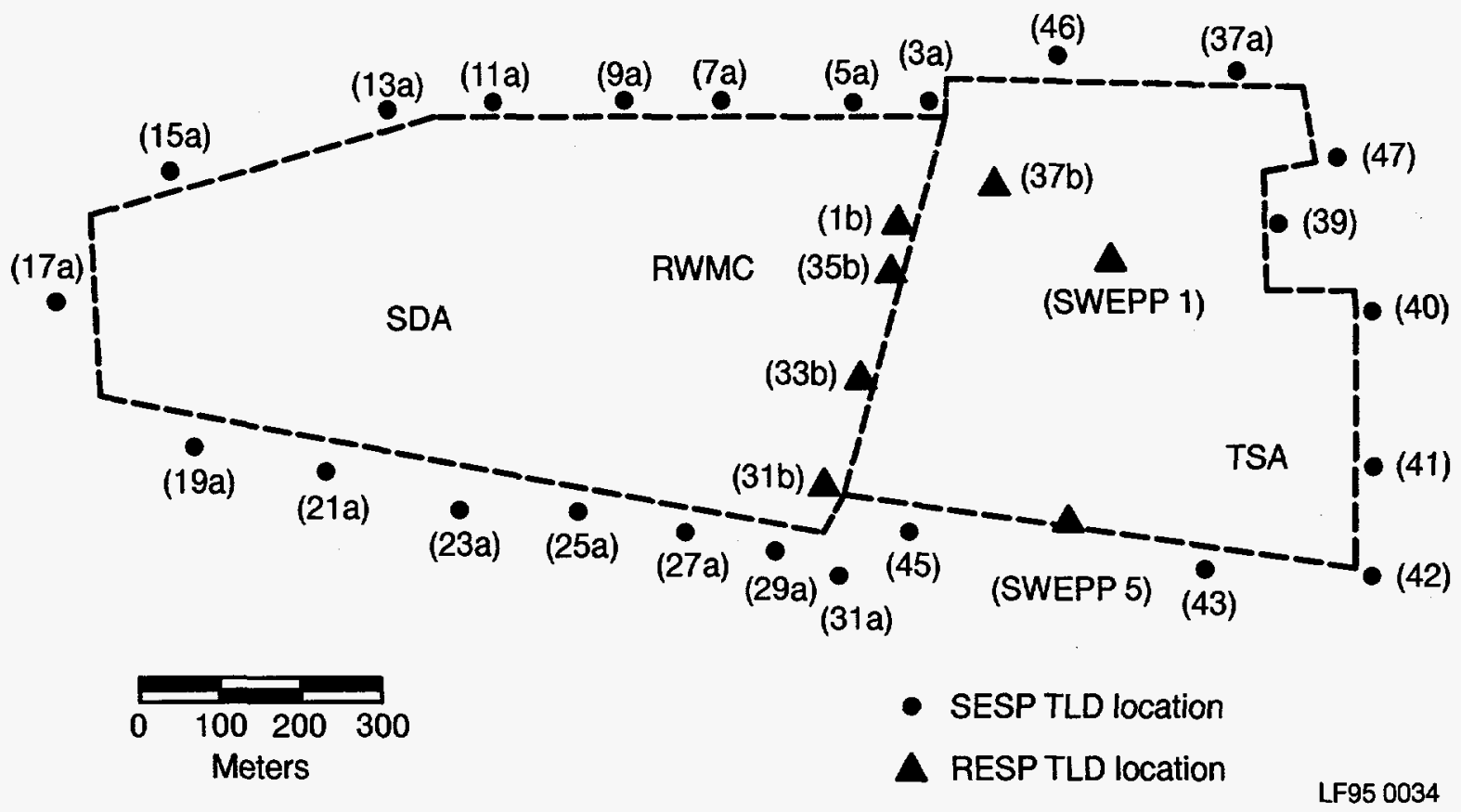

Figure 40. RWMC TLD locations.

and operational activities in that area. In addition, measured exposures at many stations in the proximity of the active pit have increased during the second reporting period. This increase is attributed to the new waste placed in the active disposal pit.

Figures 41 through 48 show the six-month exposures for the past 10 years as measured by TLDs along the following RWMC SDA borders: northwest, northeast, south, southwest, southeast, west, and east. Average distant-community background exposure is shown on each graph for comparison.

Several general observations can be made about the data presented in Figures 41 through 48. First, there is a decreasing trend in exposures over time at most locations around the SDA, especially from 1974 through 1980 . (Refer to the 1991 Annual Report for plotted data beginning approximately in 1973.) Except for the increased exposure around the active pit during 1994 , decreases can generally be attributed to the following: (a) changes in operational activities, (b) placement of additional soil over pits and trenches, and (c) radioactive decay of the radionuclides in waste already buried. Many exposures have decreased to near background exposures and tend to vary directly with background exposures.

Approximately $0.6 \mathrm{~m}$ of soil cover was added to the northern half of the SDA in 1976. From 0.3 to $2 \mathrm{~m}$ of cover was added to most of the remaining portion of the SDA in the early 1980s. In the late 1980 s and early 1990 s, recontouring projects have increased the soil cover over the majority of the SDA.

The second observation indicates that in past years, exposures are generally lower from November through May than from May through November. Lower exposures are attributed to decreased waste handling, increased snow cover, and increased soil moisture. 


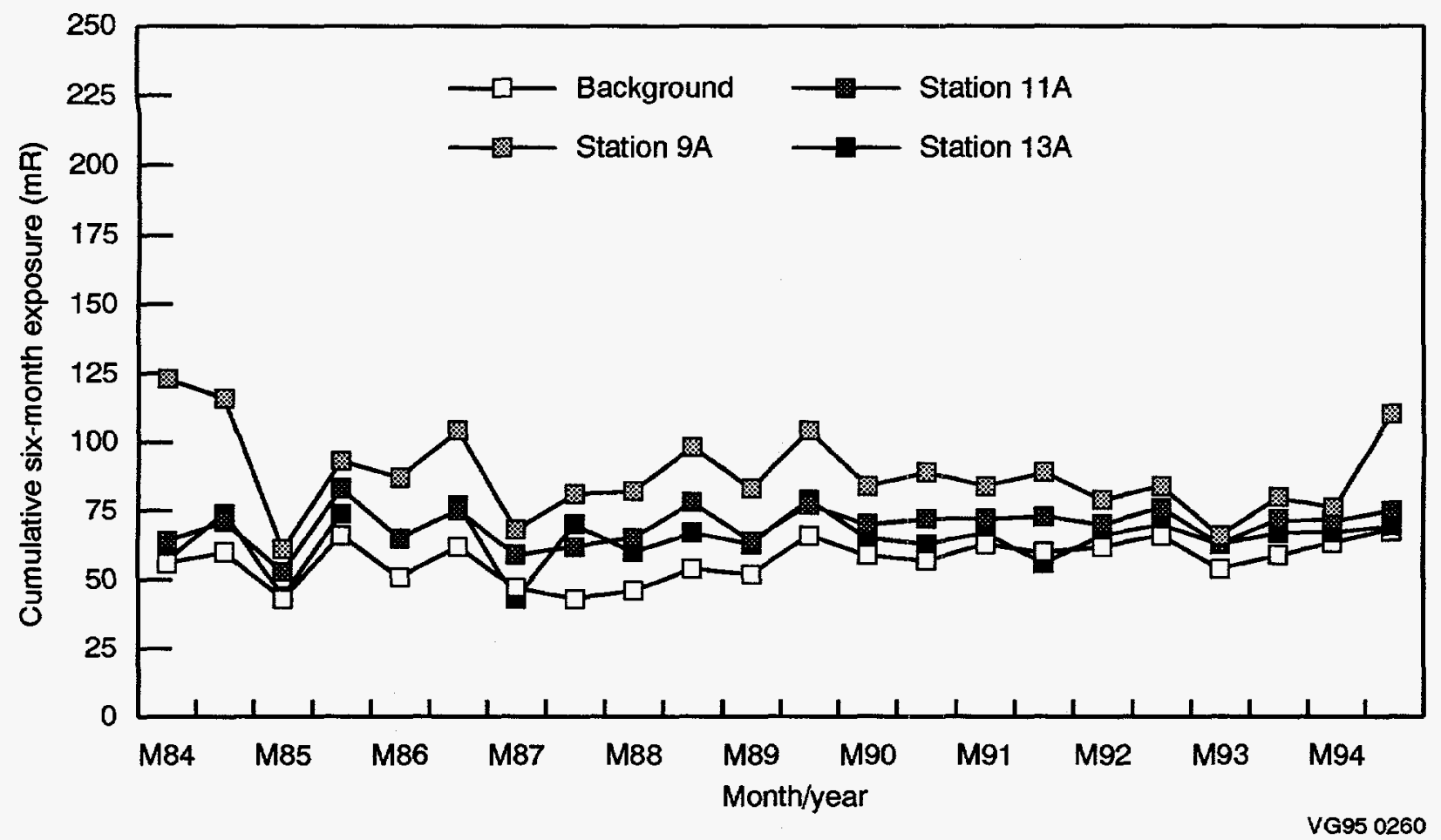

Figure 41. Six-month exposures measured by TLDs on the northwest border of the SDA.

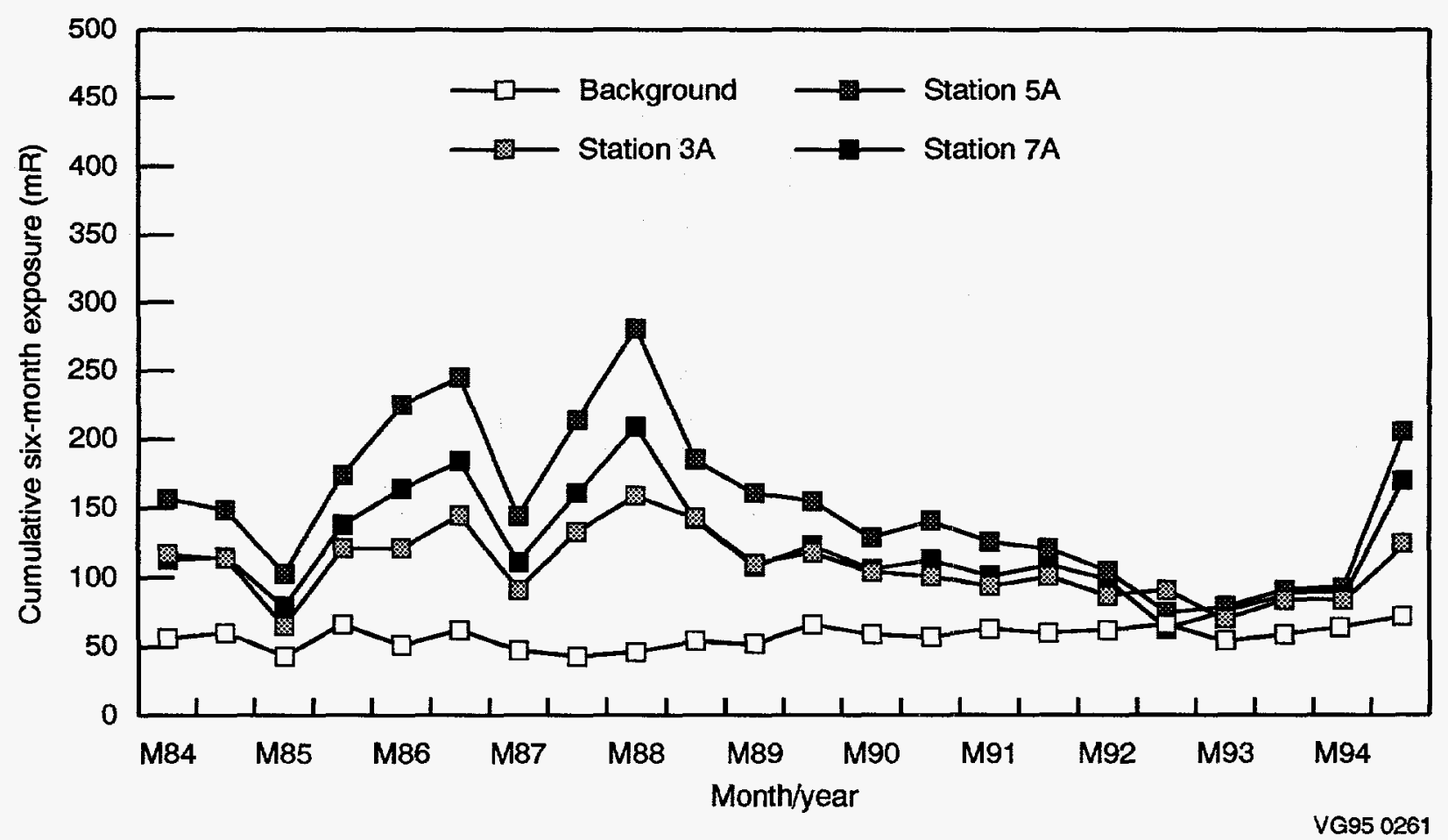

Figure 42. Six-month exposures measured by TLDs on the northeast border of the SDA. 


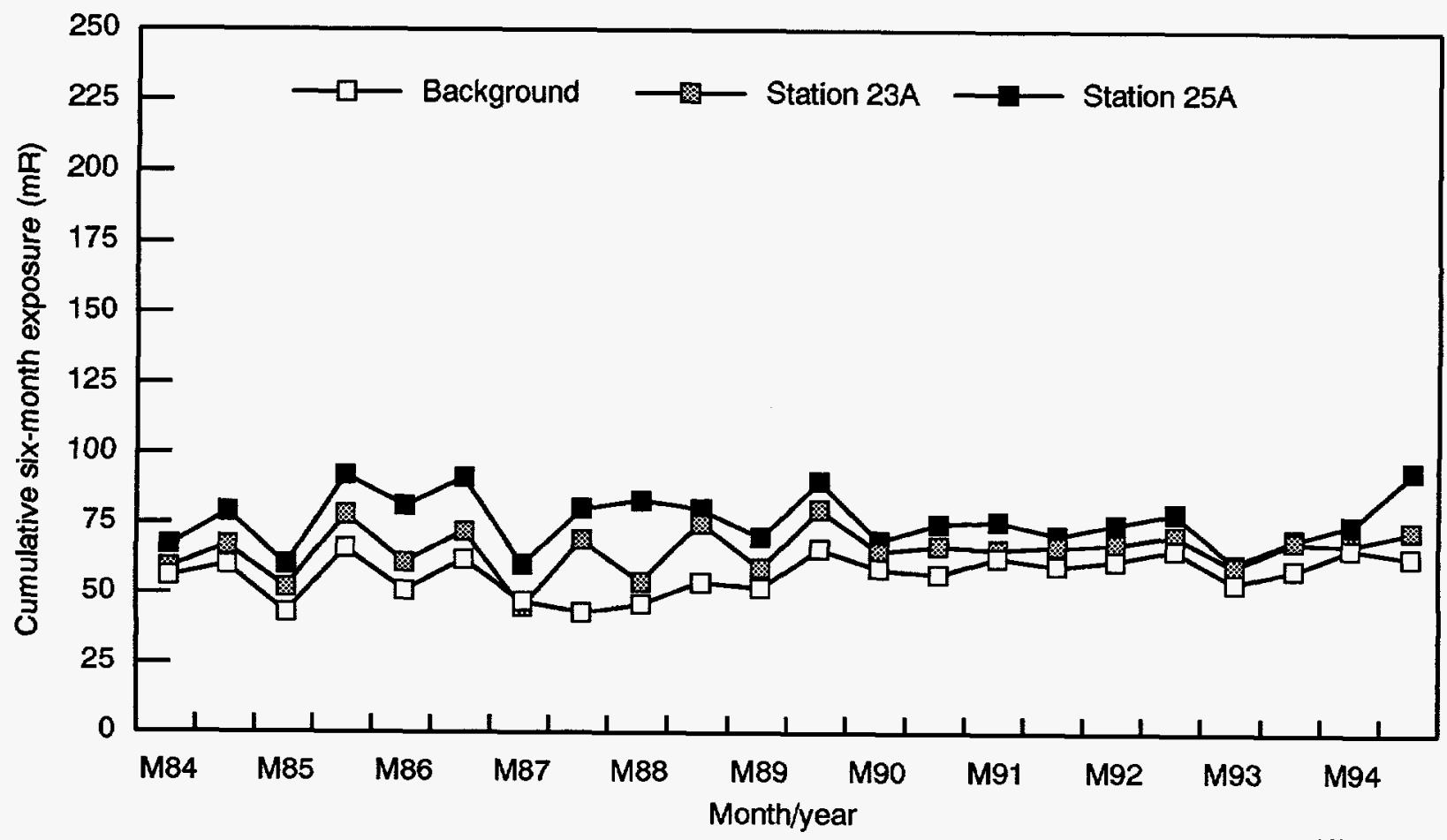

Figure 43. Six-month exposures measured by TLDs on the south border of the SDA.

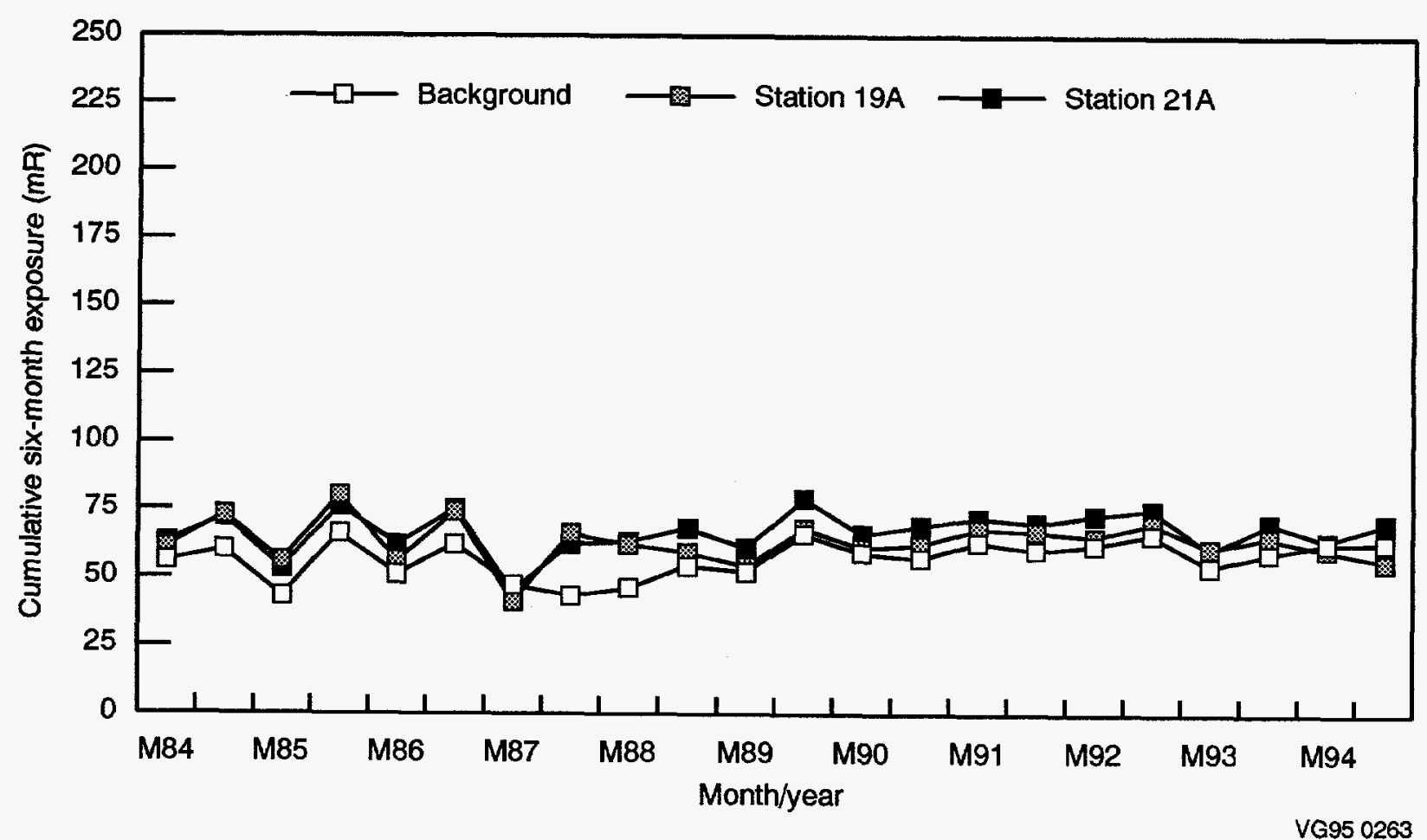

Figure 44. Six-month exposures measured by TLDs on the southwest border of the SDA. 


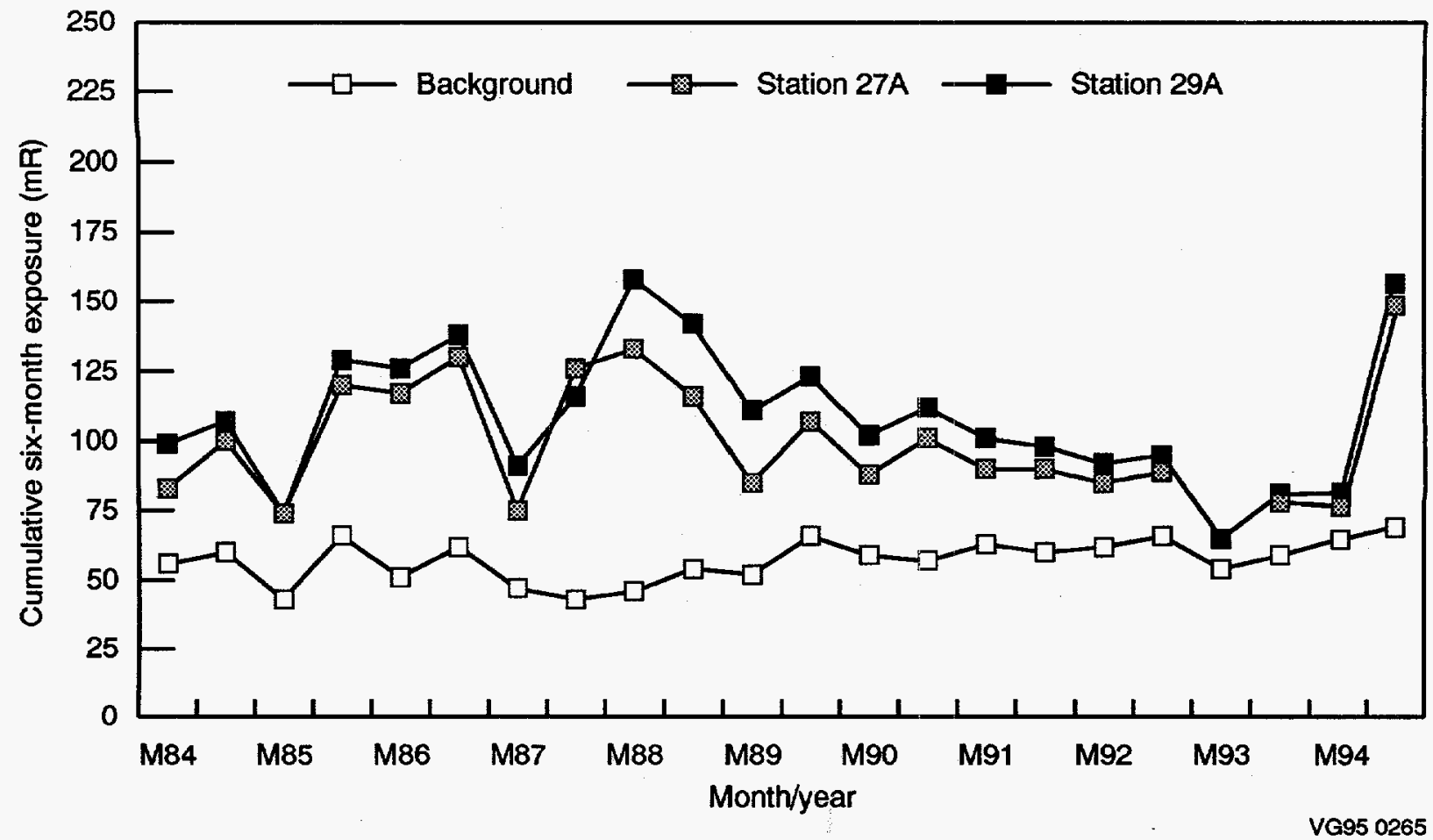

Figure 45. Six-month exposures measured by TLDs on the southeast border of the SDA.

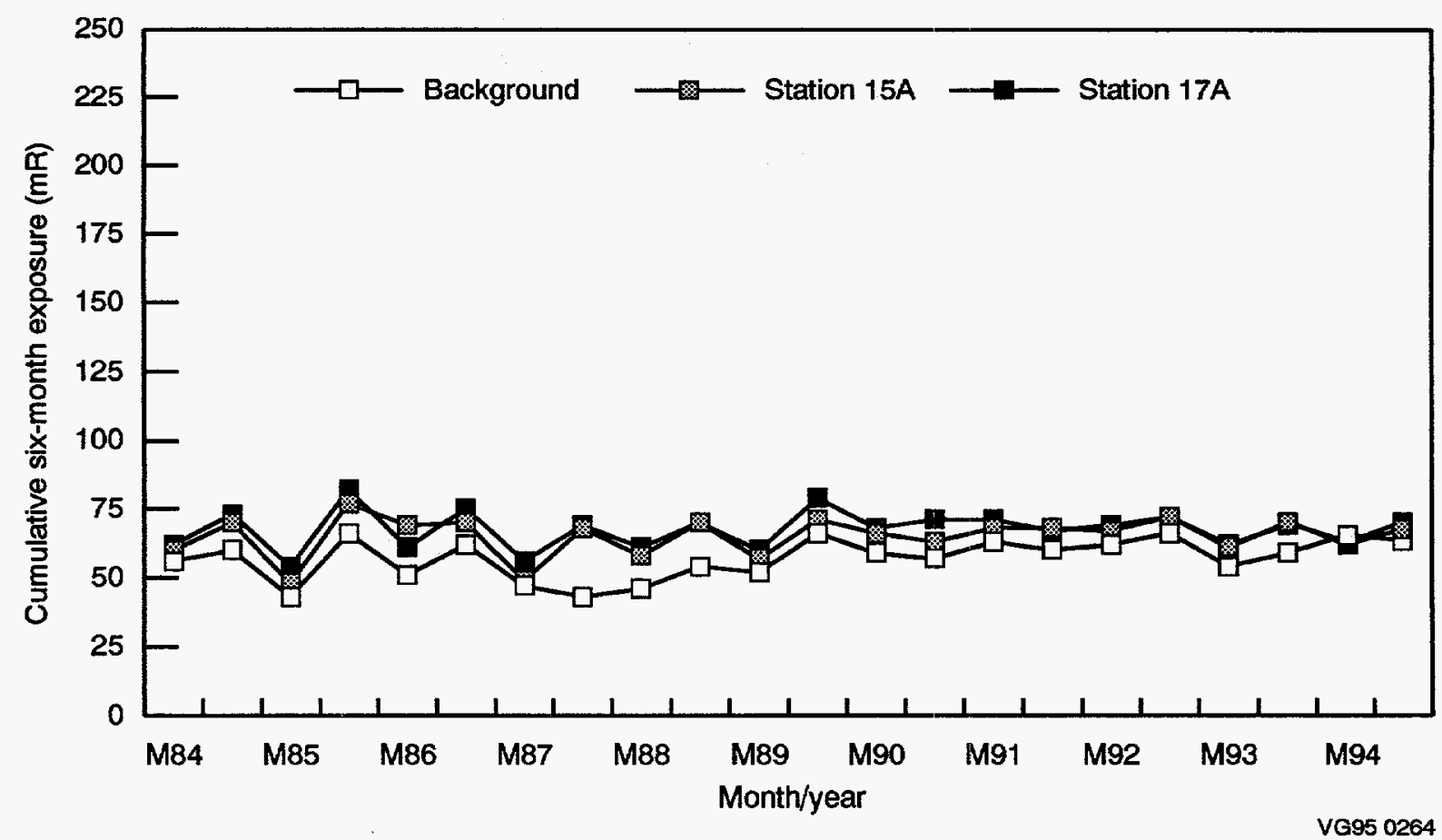

Figure 46. Six-month exposures measured by TLDs on the west border of the SDA. 


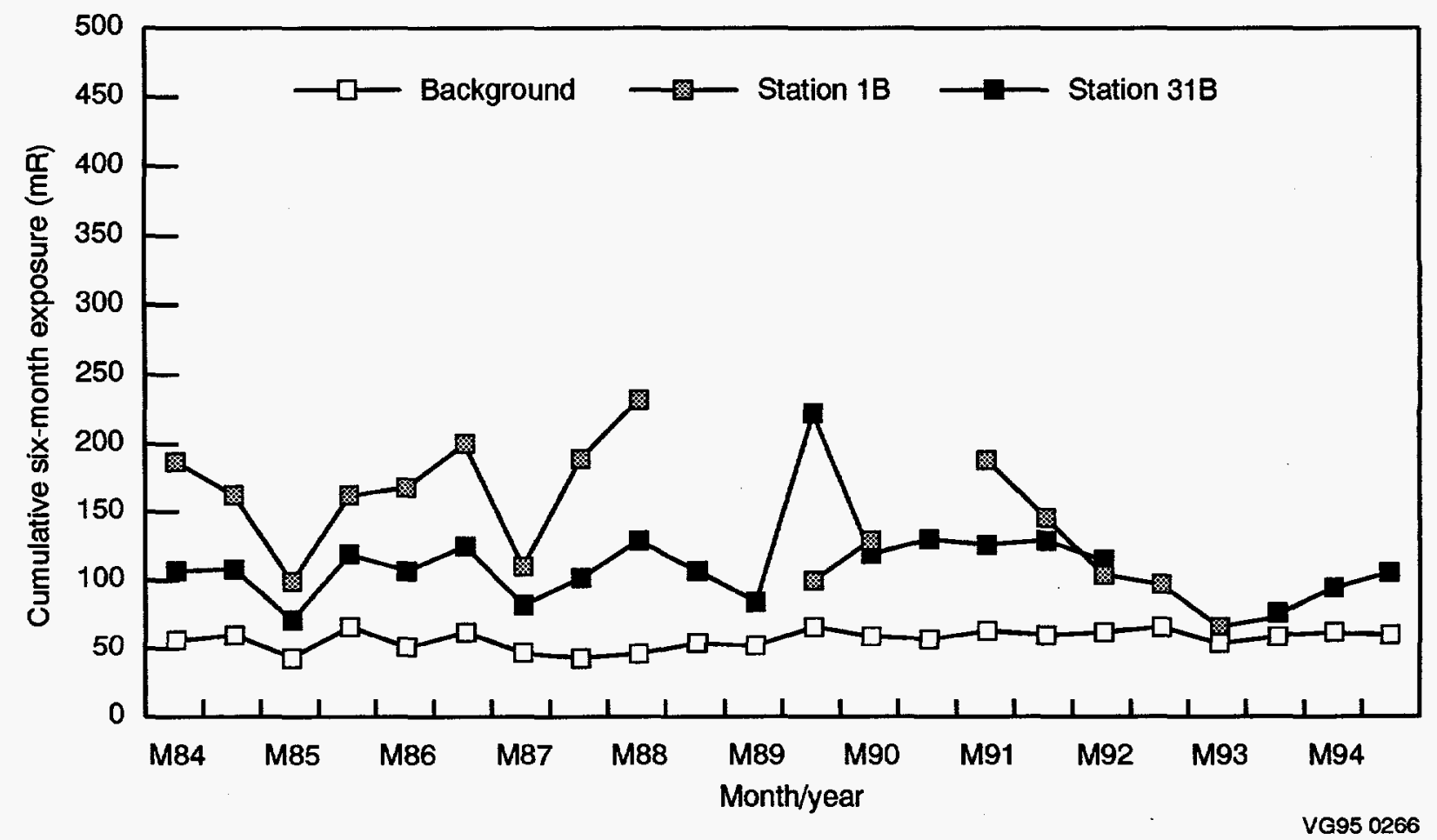

Figure 47. Six-month exposures measured by two of the four TLDs on the east border of the SDA near the active pits.

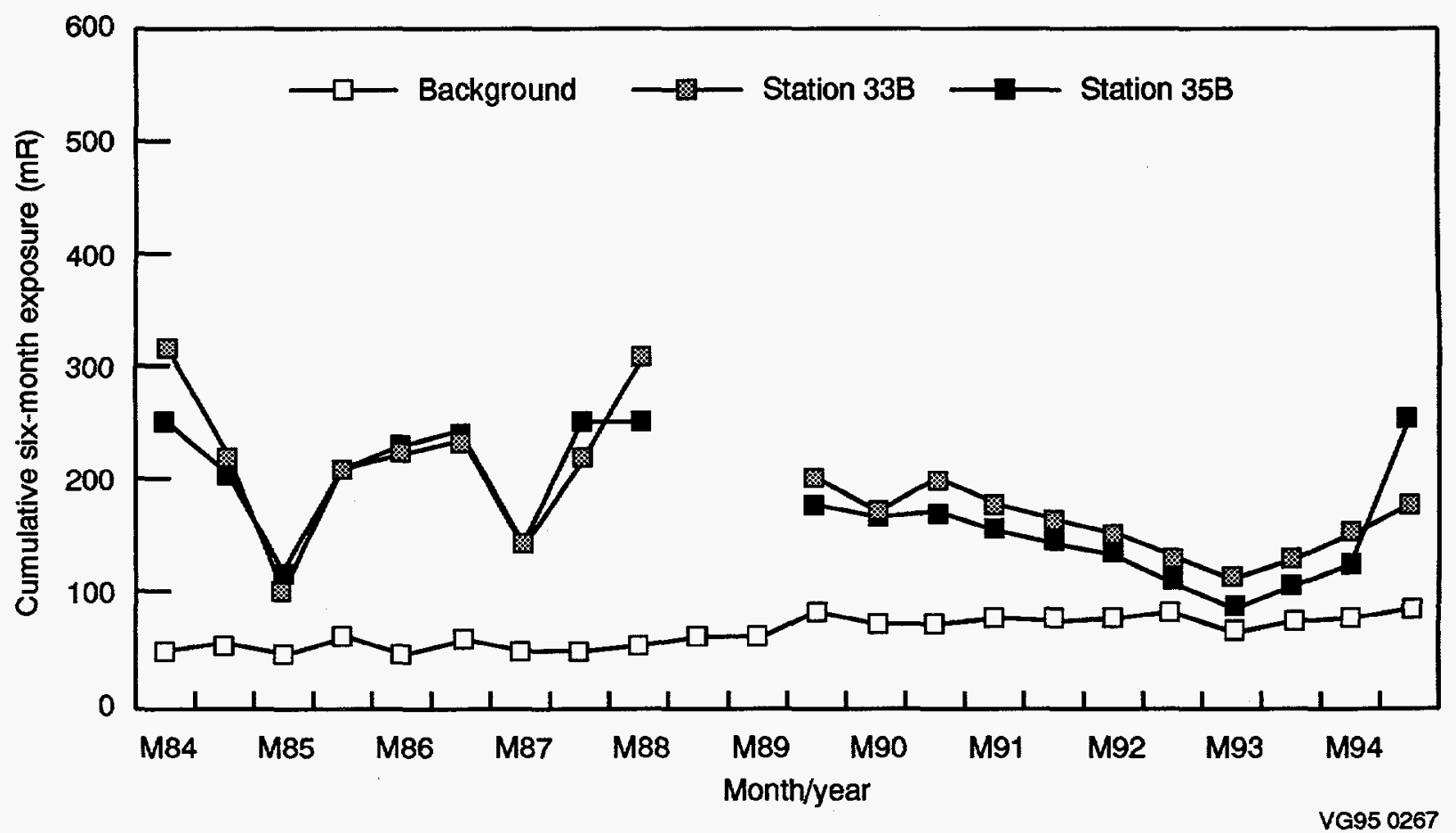

Figure 48. Six-month exposures measured by two of the four TLDs on the east border of the SDA near the active pits. 
A general increase was noted at the RWMC during 1994 due to operational activities. These activities were the storage of higher level waste in the bulk waste area within the active disposal pit and waste movement from the ILTSF to the $\mathrm{C} \& \mathrm{~S}$ building during the second reporting period of 1994.

Figure 41 presents plots of exposures measured at Stations 9A, 11 A, and 13A (along the northwest SDA border). Station 9A is located near the west end of Pad A, and Stations 11A and 13A are located along the northern part of the original burial ground (operated from 1952 through 1957). This area contains buried LLW intermixed with TRU waste. The exposures at Station 9A have generally decreased over time. The elevated exposures during 1983 and the first half of 1984 are attributed to the temporary parking of vehicles carrying waste shipments on the west side of Pad A. Exposures have decreased at Stations $11 \mathrm{~A}$ and $13 \mathrm{~A}$ over the years and remain at or near background levels for both 1994 reporting periods. However, Station 9A increased to approximately twice background during the second reporting period due to the operational activities discussed previously.

Exposures measured at Stations 3A, 5A, and 7A (northeast SDA border) are plotted in Figure 42. Station $3 A$ is located near Pit 9, which contains TRU waste, and Station $5 \mathrm{~A}$ is located near Pit 8 , which contains LLW. Both pits were closed in 1969. Station 7A is located near the east end of Pad A. During 1985 through 1988, waste was temporarily stored east of these locations and contributed to the increased exposure rate during those years. Exposures returned to twice background from 1989 to the spring of 1994 , and increased to nearly three times background during the second reporting period of 1994 . This most recent increase is also due to previously discussed operational activities.
Figure 43 shows exposures measured at Stations $23 \mathrm{~A}$ and $25 \mathrm{~A}$, which are located along the south central border of the SDA. The trenches near these stations contain LLW intermixed with TRU waste and were closed in 1959 . With the exception of the second reporting period for Station $25 \mathrm{~A}$, the exposures at these stations have generally decreased over time, and Station $23 \mathrm{~A}$ is now at or near background exposure levels. Exposure levels increased due to operational activities in the second reporting period.

Figure 44 shows exposures measured at Stations $19 \mathrm{~A}$ and $21 \mathrm{~A}$, which are located along the southwest border of the SDA. These stations are located near soil vaults, which are cylindrical holes drilled into the ground. Soil vaults have been designed for disposal of special wastes with radiation levels exceeding $500 \mathrm{mR} / \mathrm{h}$ at $0.91 \mathrm{~m}$. The soil vaults in this area have been closed since 1979. Since 1982, exposures have continued to be consistently near the background exposure levels.

The exposures plotted in Figure 45 are for Stations $27 \mathrm{~A}$ and $29 \mathrm{~A}$, which are located on the southeast border of the SDA, south of Pit 17 (which is active). Since the early 1980s, before Pit 17 was actively used, the exposures at $27 \mathrm{~A}$ and $29 \mathrm{~A}$ remained consistent at two times the background exposure levels. Until the second reporting period of 1994, exposures have been decreasing and approaching background levels. As stated previously, these stations also showed an increase during the second reporting period of 1994 due to operational activities.

Figure 46 presents plots of exposures measured at Stations 15A and 17A, which are located on the west SDA border (next to the original burial ground). Exposures at these stations have been variable due to operational activities but generally have decreased over time. Current exposures remain consistent and are at or near background levels. 
Figures 47 and 48 show that exposures at Stations $1,31,33$, and 35 had been decreasing until May 1993 and have increased since then due to operational activities. No data were available for either of the reporting periods during 1994 for Station 1B because the TLD could not be located during the change-out. These are the closest stations to the pits that have been active since 1974 . Generally exposures measured at these stations have been the highest observed at the SDA and vary with the proximity and intensity of operational activity. Data are no longer available from Stations 1, 31, 33, and 35 due to construction in the area. However, data are reported for the second half of 1989 through the present at Stations 1B, 31B, 33B, and 35B. These locations are $15 \mathrm{~m}$ east of the original locations and are closer to the ILTSF at TSA. Current exposures are increasing, and the exposure during the second reporting period for Station 35 was the highest noted in 1994. These stations are in close proximity to the active pit area and also showed an increase in the second reporting period due to the operational activities.

Figures 49 through 53 are plots of exposures measured by TLDs along the north, south, and east borders of the TSA, respectively.

Exposures measured at Stations 37A, 39, and SWEPP 1, which are located along the north border of the TSA, are plotted in Figure 49. The exposures at these locations are variable over time. These stations are near an area where incoming shipments are placed until the waste can be disposed. These waste shipments are, in effect, point sources of radiation. Another factor in the variability of the past years exposures at these stations was the temporary storage of waste on the asphalt pad in the TSA area during the late 1980s. Exposures at Station 37A have been decreasing and are approaching background levels. No waste has been stored in this area for the past three years. The exposures at Station 39 and SWEPP 1 have been consistent during the past three years at approximately one and one-half times the background level.
Exposures measured at Stations SWEPP 5, 42, 43 , and 45, which are located along the south and southeast borders of the TSA, are shown in Figures 50 and 51 . These exposures are consistently low and usually vary directly with background exposures. However, these stations also showed a slight increase during the second reporting period of 1994 and may also be due to the operational activities.

Exposures measured at Stations 40 and 41, which are located along the east and northeast borders of the TSA, are shown in Figure 52. Station 41 exposures are fairly consistent and are close to background exposures. Station 40 showed a large increase during the second half of 1987 , and then returned to its typical range. The 1987 increase has been attributed to the temporary storage of drums near the drum venting station during that year. Current exposures at Station 40 are at or near background exposures. However, Station 41 also showed an increase during the second reporting period of 1994 due to the same operational activities discussed previously.

Figure 53 shows exposures measured at Stations 46 and 47 , located along the north border of TSA. In May 1989, the security fence was increased in size, and these two stations were added since the security fence had been expanded. These exposures have been fairly consistent with background exposures. However, Station 46 also showed the same, slight increase during the second reporting period of 1994. Exposure data were not reported for Station 47 during the second reporting period because the TLD could not be located during change out.

\section{Waste Experimental Reduction Facility}

Figure 33 shows the locations of the 11 TLD stations located around the WERF. Figures 54 through 59 show the six-month exposures measured by TLDs located in the WERF area. 


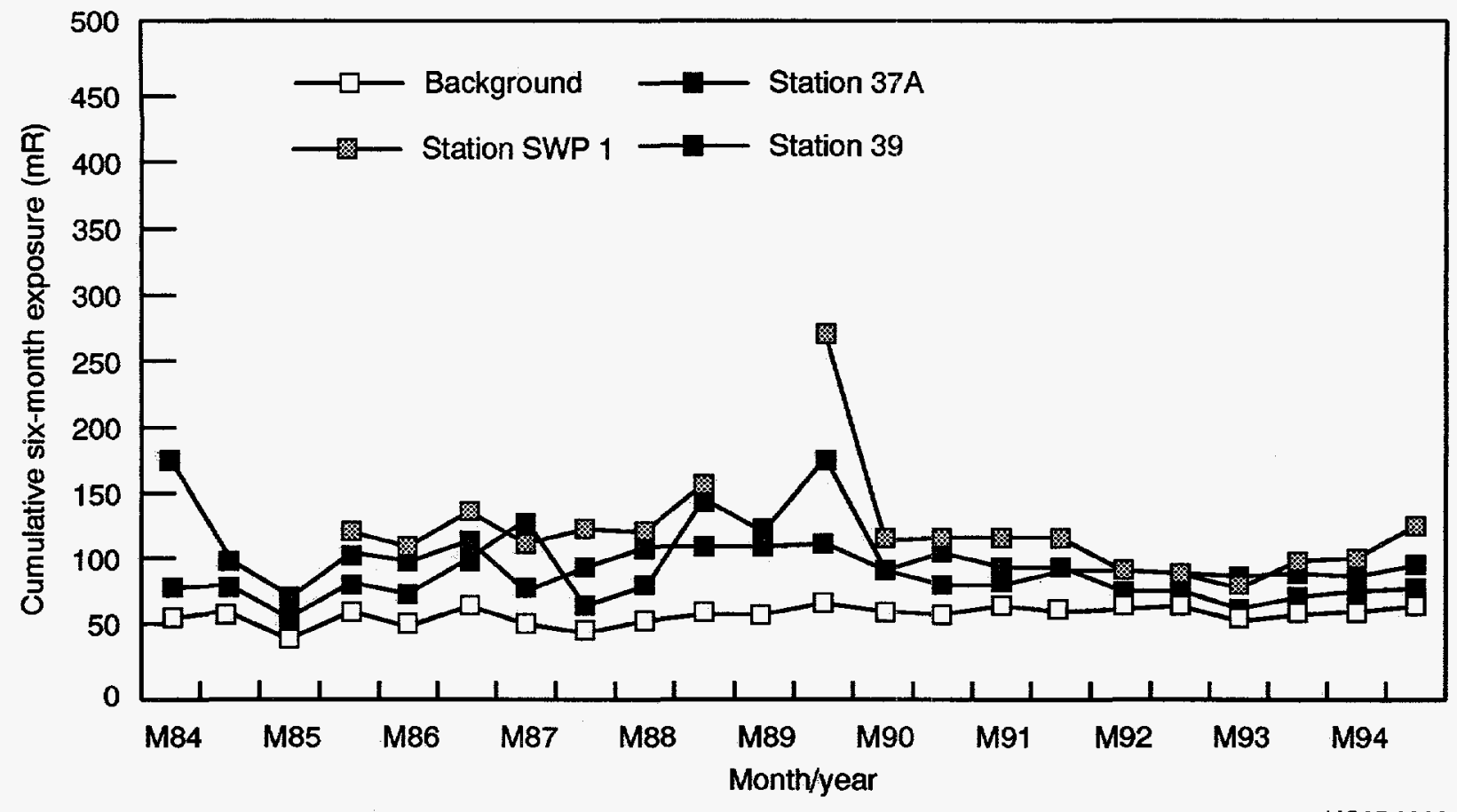

Figure 49. Six-month exposures measured by TLDs on the north border of the TSA.

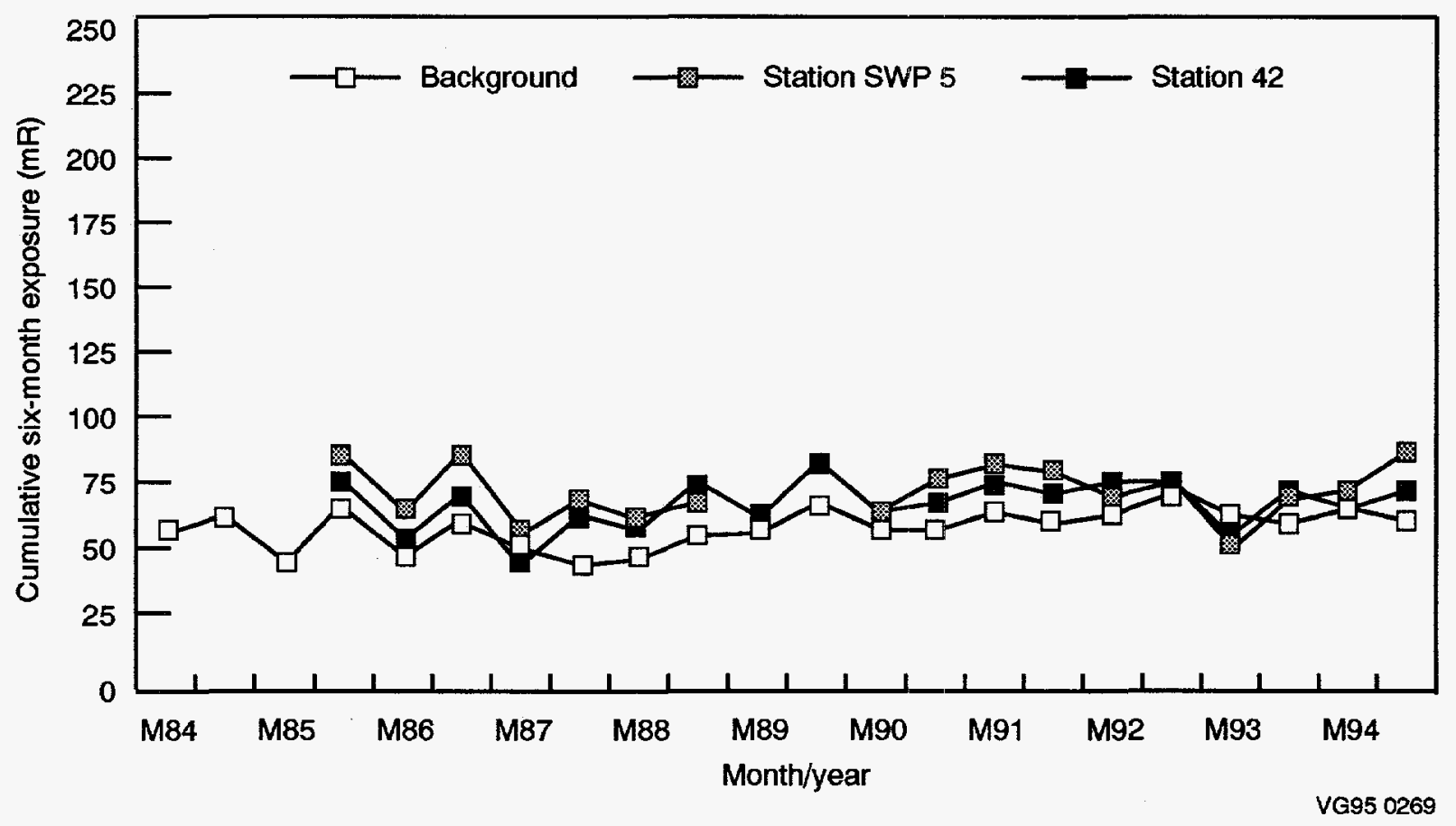

Figure 50. Six-month exposures measured by two of the four TLDs on the south and southeast borders of the TSA. 


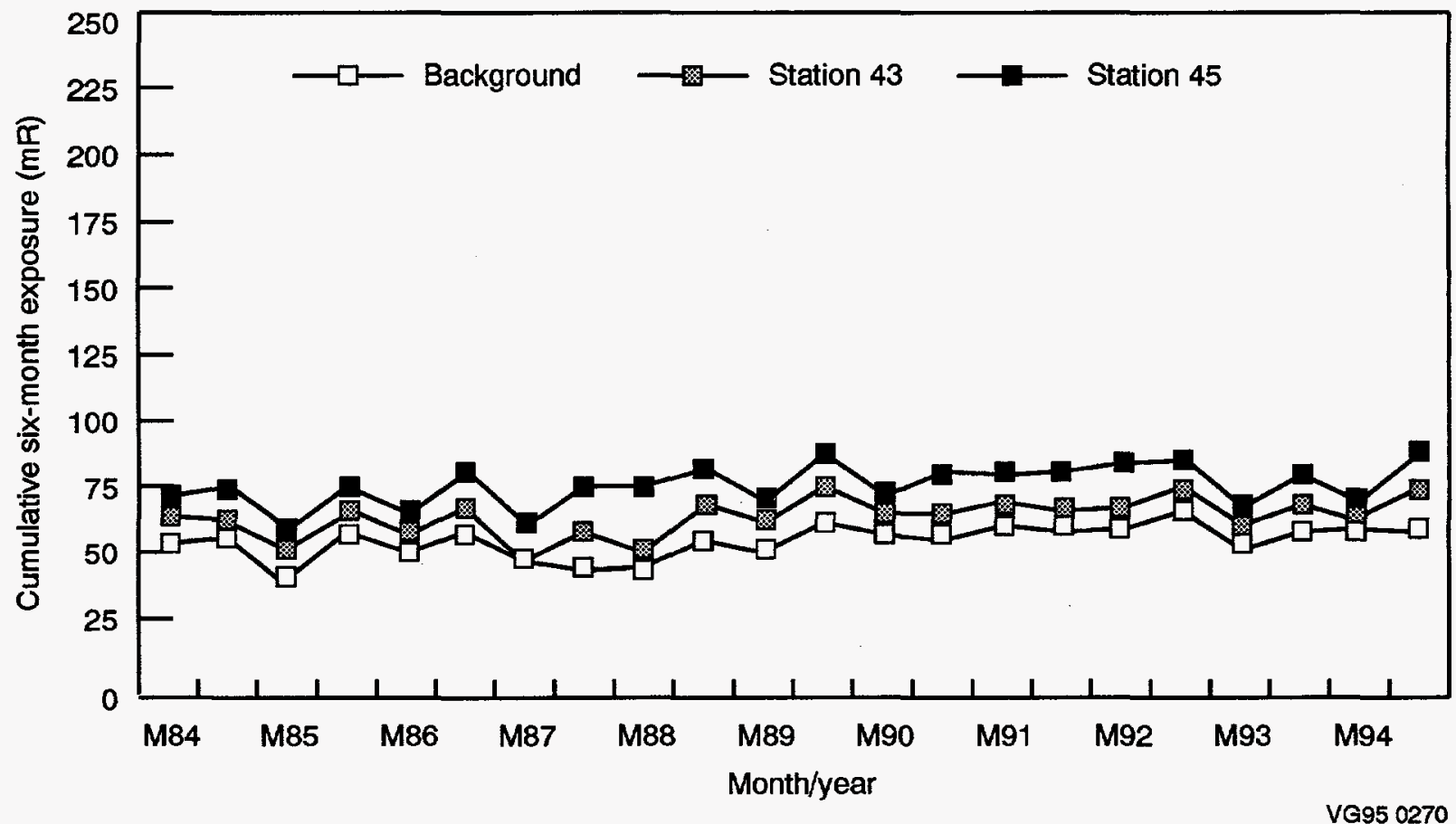

Figure 51. Six-month exposures measured by TLDs on the south border of the TSA.

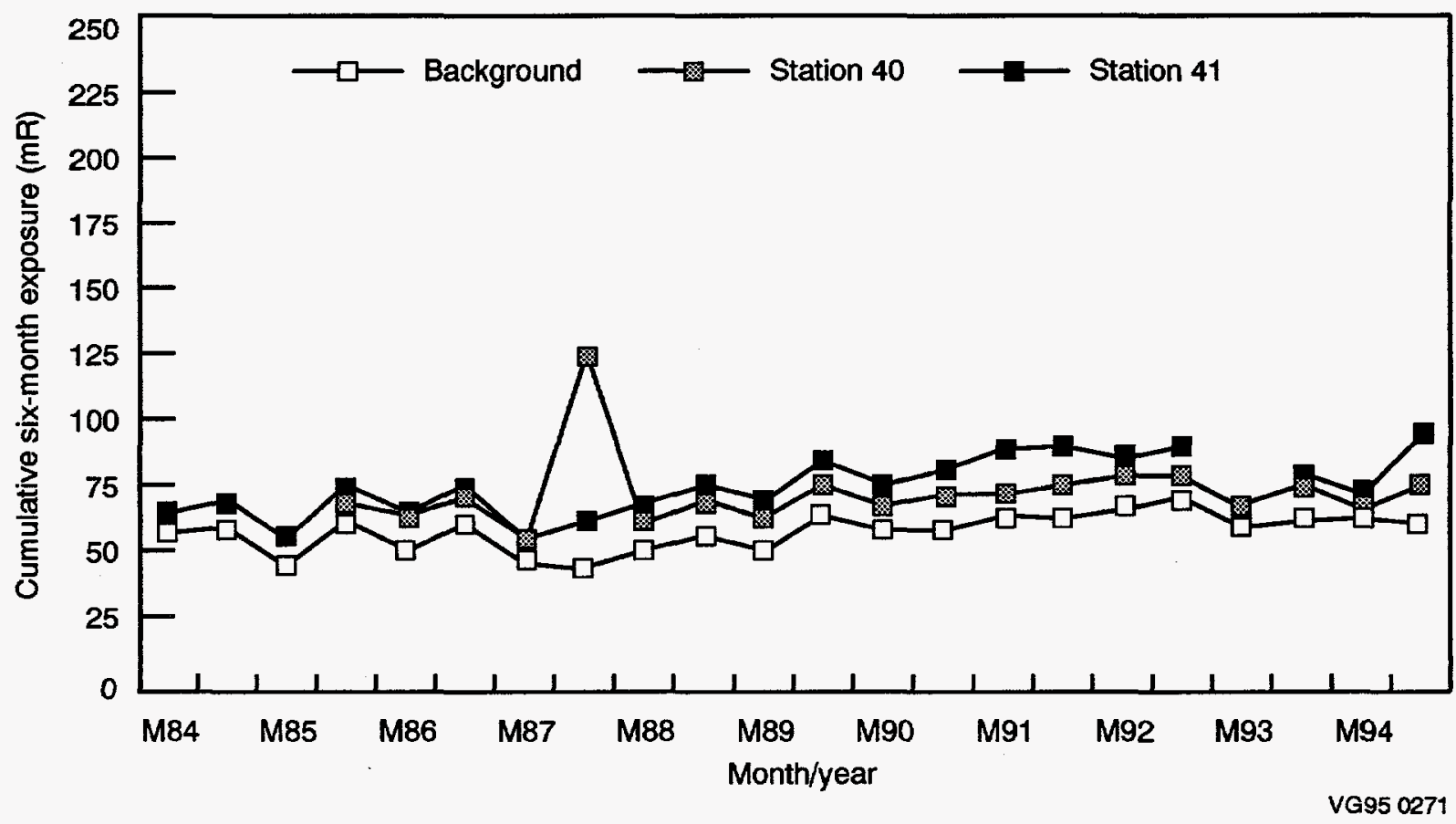

Figure 52. Six-month exposures measured by TLDs on the east and northeast borders of the TSA. 


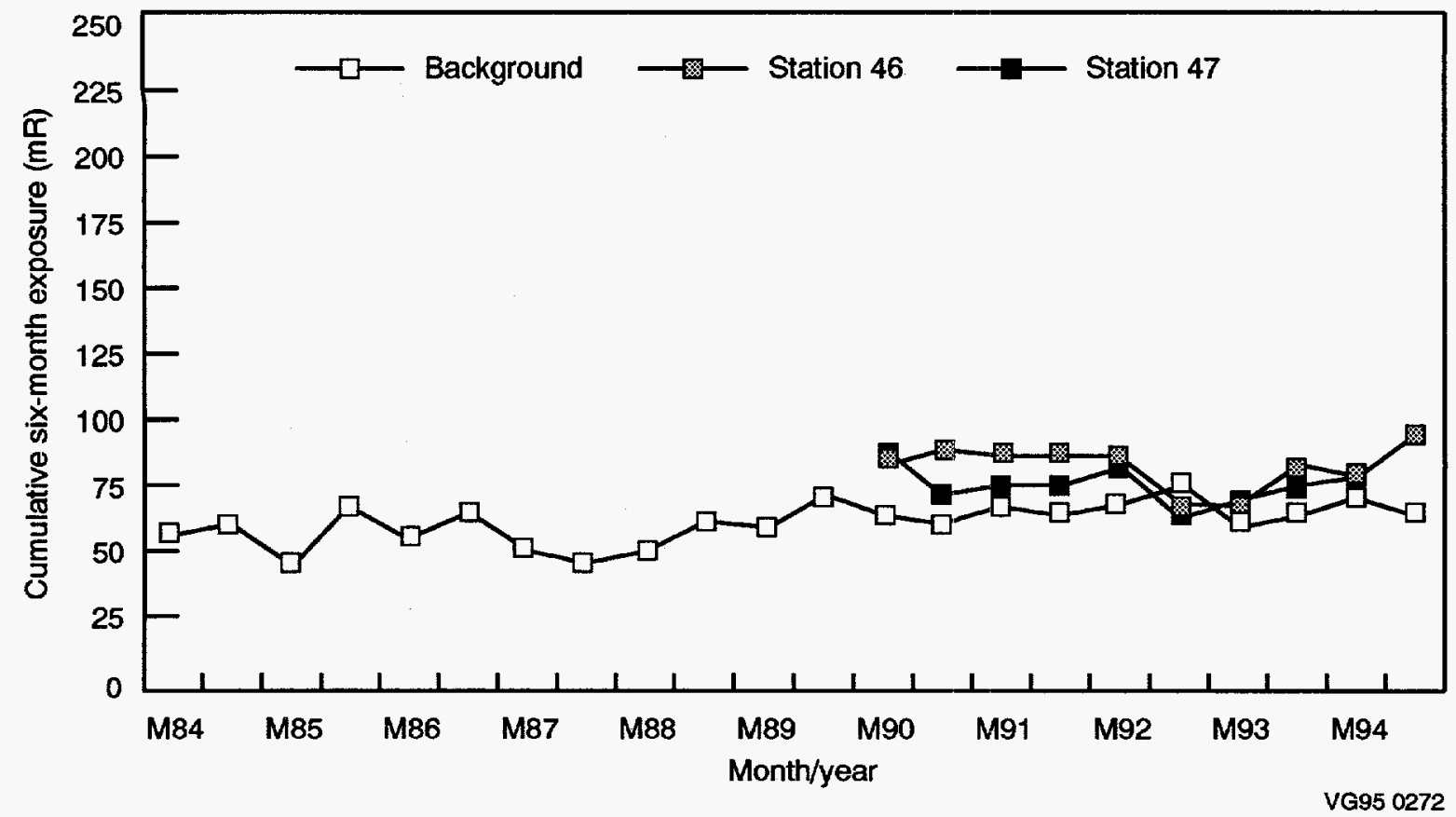

Figure 53. Six-month exposures measured by TLDs north of TSA.

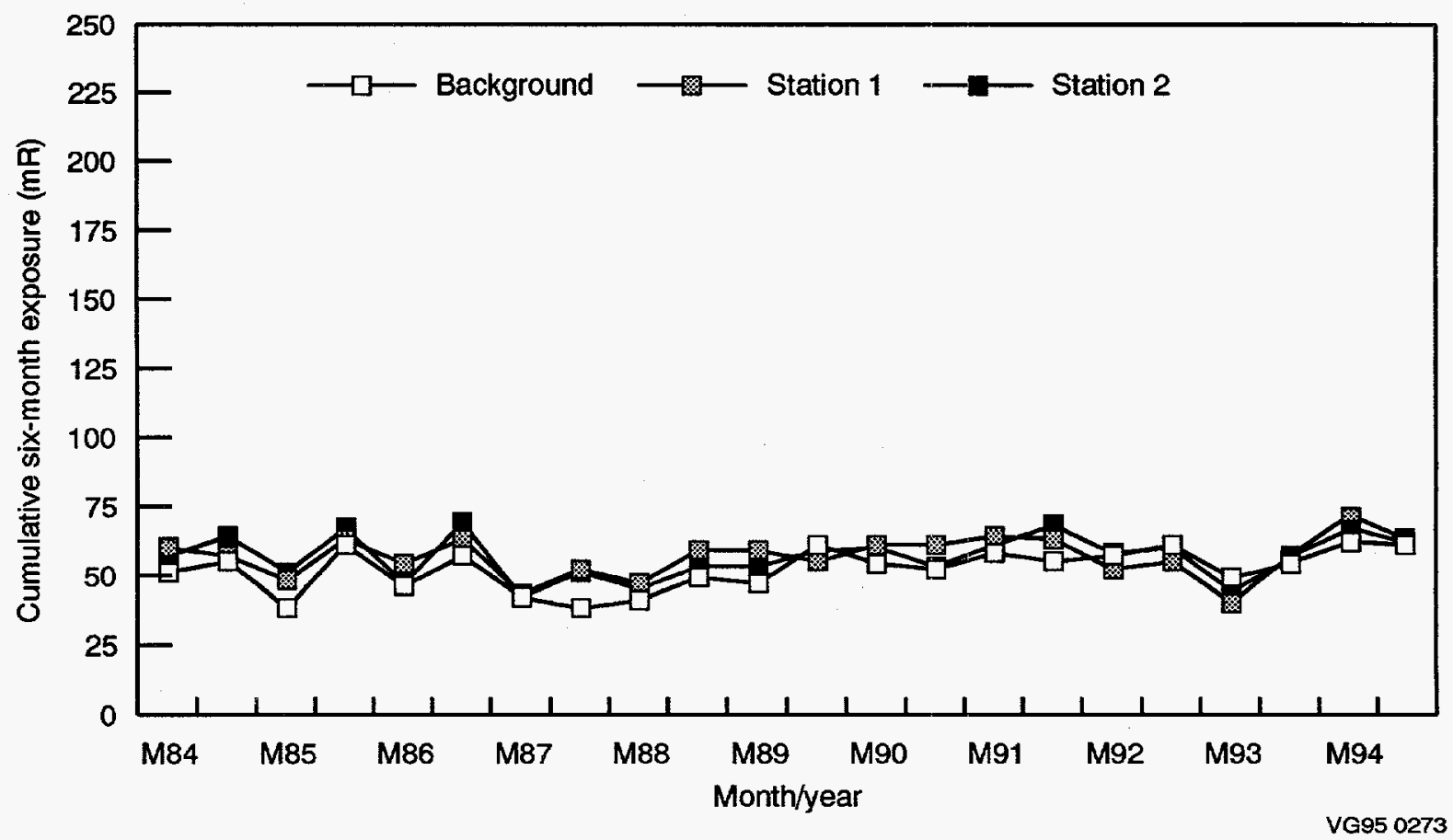

Figure 54. Six-month exposures measured by TLDs located $500 \mathrm{~m}$ and $400 \mathrm{~m}$ northeast of WERF. 


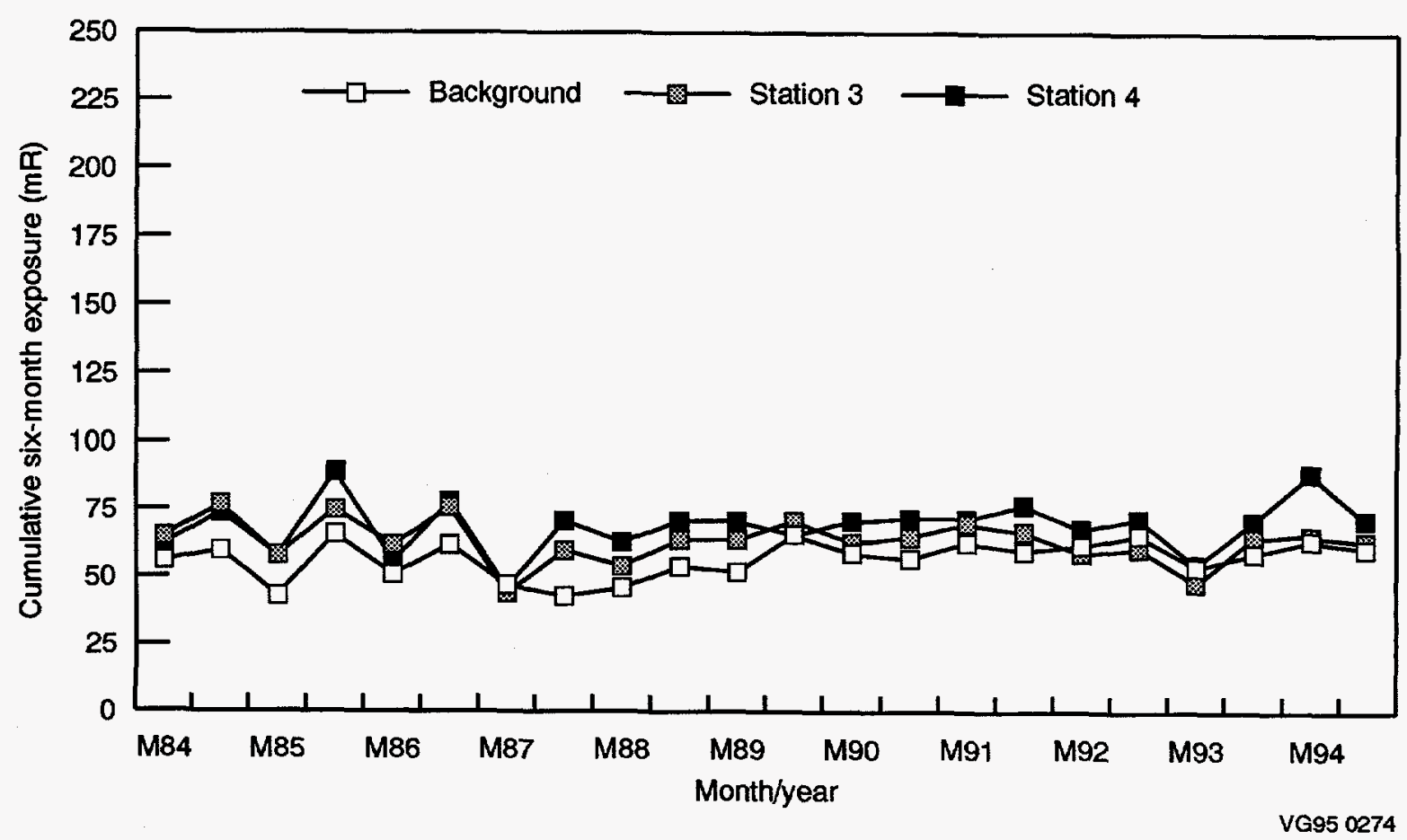

Figure 55. Six-month exposures measured by TLDs located $300 \mathrm{~m}$ and $200 \mathrm{~m}$ northeast of WERF.

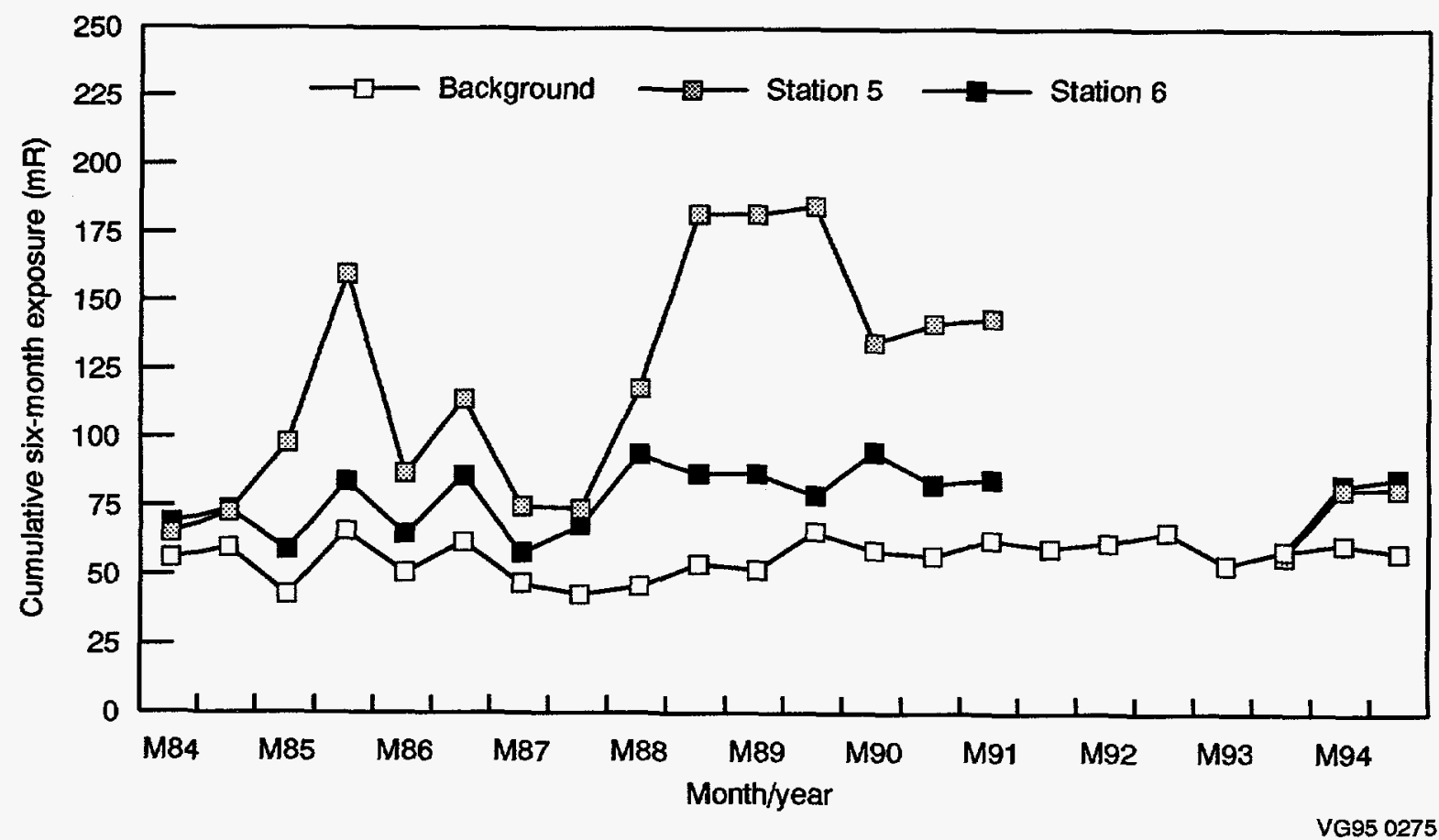

Figure 56. Six-month exposures measured by TLDs located northeast and southeast of the 50-m perimeter around WERF. 


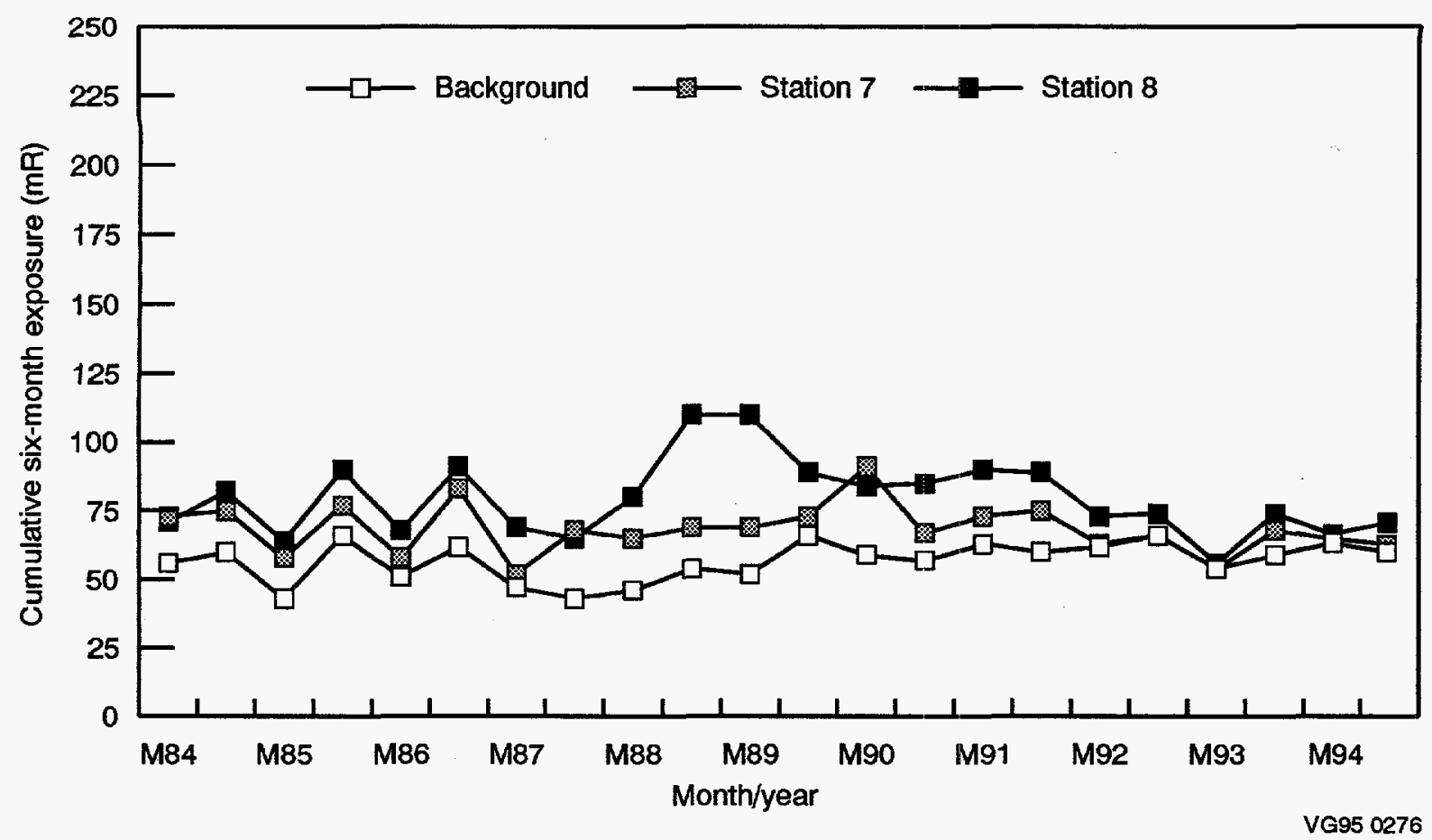

Figure 57. Six-month exposures measured by TLDs located southwest and northwest of the 50-m perimeter around WERF.

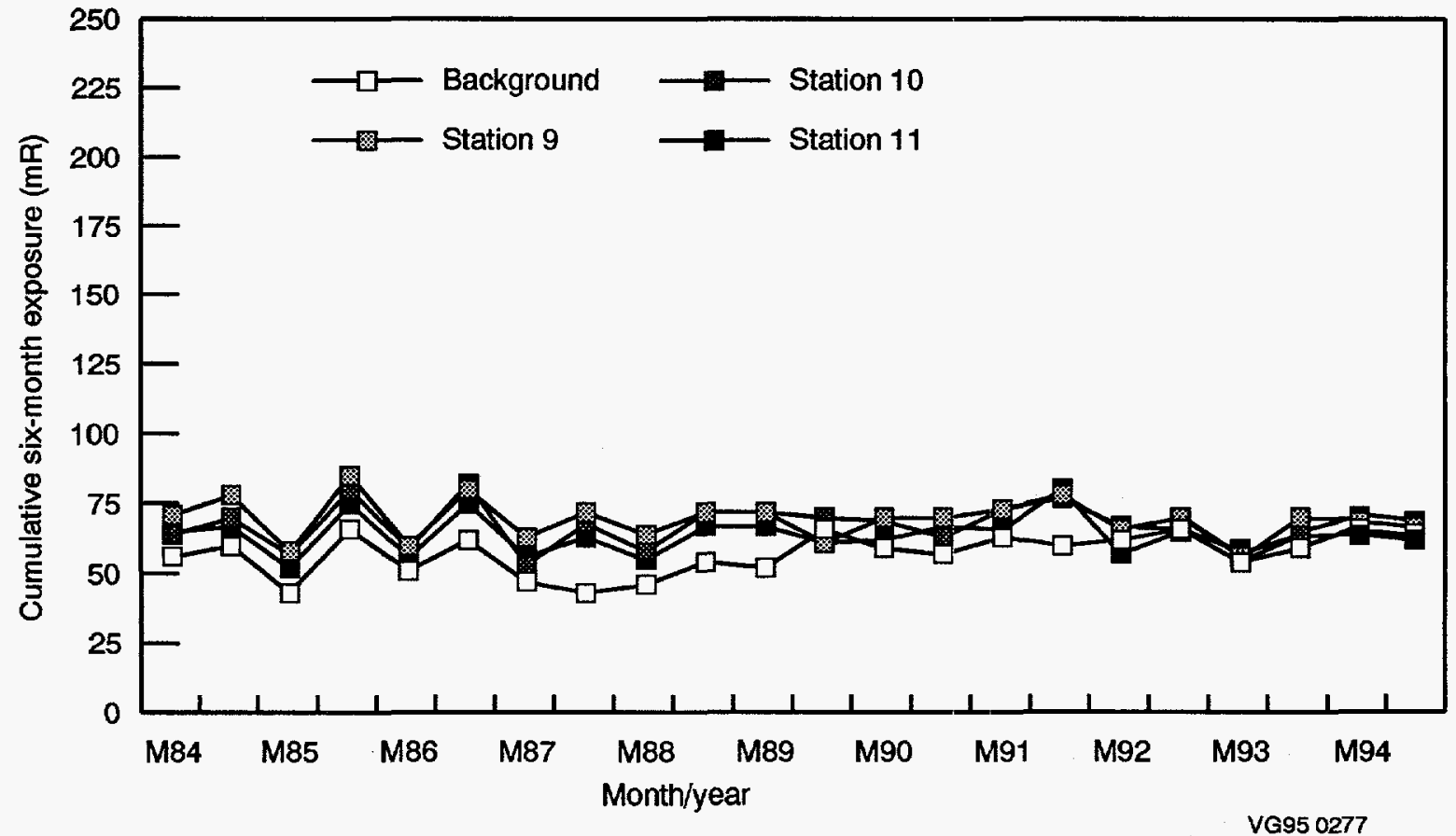

Figure 58. Six-month exposures measured by TLDs located northwest, southwest, and southeast of the perimeter around WERF. 


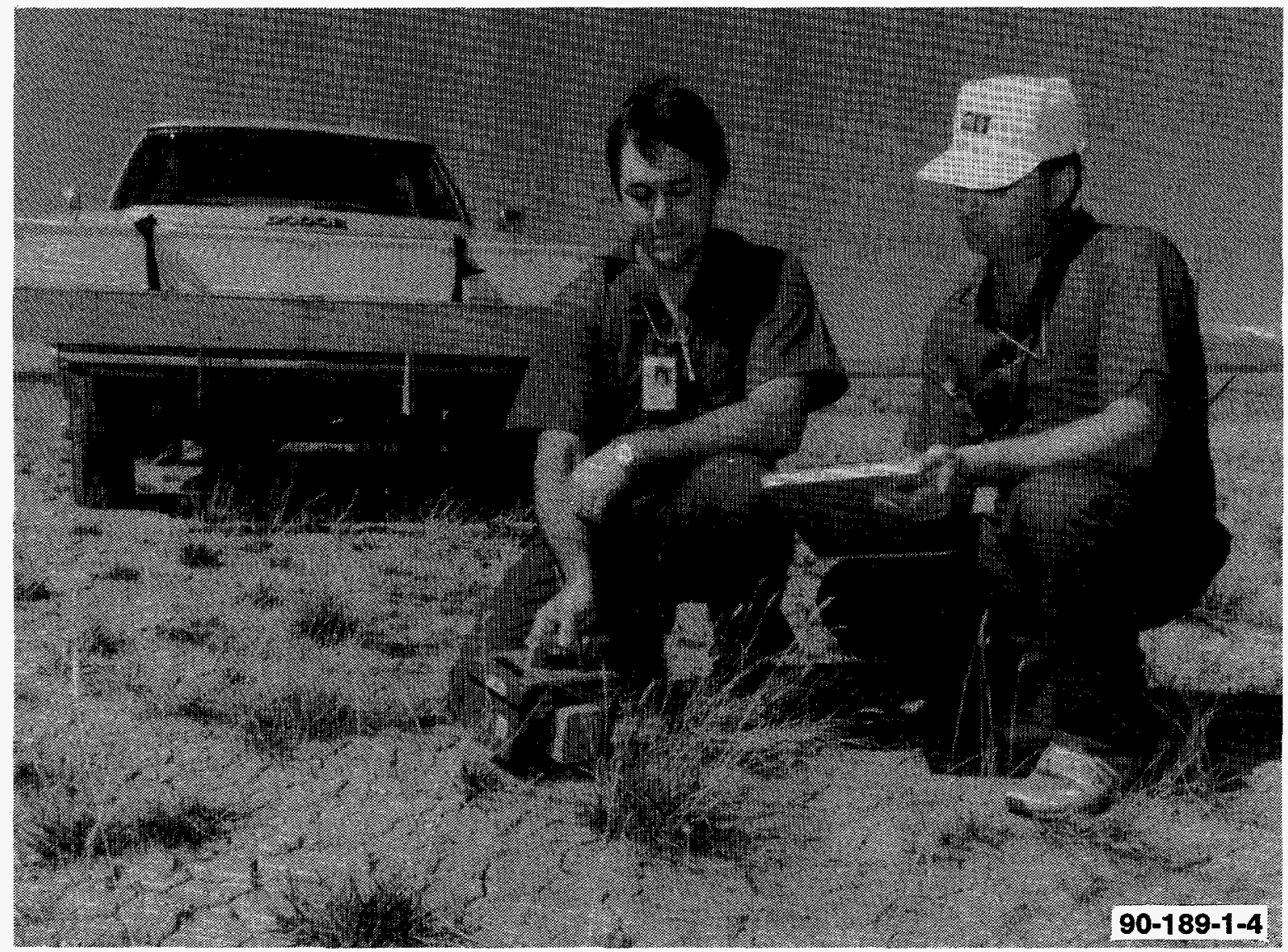

Figure 59. VRM-1 and HHD-440 meter radiation detector system.

Figures 54 and 55 show the exposures measured at Stations 1, 2, 3, and 4, which are located northeast of WERF along the predominant wind direction. Stations $1,2,3$, and 4 are located $500 \mathrm{~m}, 400 \mathrm{~m}, 300 \mathrm{~m}$, and $200 \mathrm{~m}$ from WERF, respectively. Exposure levels at these stations remain at or near background with the exception of Station 4, which showed an increase during the first reporting period in 1994. Station 4 is located in the proximity where waste is stored. However, the associated uncertainty on this data point was higher than normal. RESP personnel will continue to evaluate this increase as data from calendar year 1995 are received.

Figures 56 and 57 show the exposures measured at Stations 5, 6,7, and 8 , which are located $50 \mathrm{~m}$ from WERF in the following directions, respectively: northeast, southeast, southwest, and northwest. Stations 5 and 8 are located near an area where waste is stored prior to processing. Some variability in exposures, especially at Station 5 , is due to temporary parking and storage of waste shipments in those areas; these waste shipments are, in effect, point sources of radiation. This accounts for the increase in exposures at Stations 5 and 8 during 1988 and the continued increase at Station 5 during 1989. Waste stored in the storage area adjacent to Station 8 was removed during the second half of 1989. Part of the waste stored near Station 5 was removed in 1990. Stations 5 and 6 were removed during 1992 due to construction in the area and was replaced during 1993 at the same locations. Exposures at Stations 7 and 8 are close to background exposures. Exposures at Stations 5 and 6 increased during 1994 due to additional waste being stored in these areas.

Figure 58 shows the exposures measured at Stations 9, 10, and 11, which are located $400 \mathrm{~m}$ from the WERF area in the following directions, respectively: northwest, southwest, and southeast. The exposures at each of these stations have remained fairly consistent over time and remain consistent with background exposures. 


\section{Surface Radiation}

To conduct the surface gamma-radiation surveys, a vehicle-mounted roadway monitor-1 (VRM-1) gamma-radiation detector system using plastic scintillation detectors (shown in Figure 59) was mounted $0.9 \mathrm{~m}$ above the ground on the front of a four-wheel-drive vehicle. The vehicle was driven at approximately $5 \mathrm{~km} / \mathrm{h}$ across each area. As radiation levels greater than background levels were identified, the vehicle was stopped and the area was surveyed with a gamma-sensitive portable instrument. Any areas exceeding the facility limits were marked with flagged stakes for subsequent covering with additional soil.

\section{Radioactive Waste Management Complex}

The contact radiation readings of the 1994 spring and fall surveys at the RWMC are shown in Figure 60. All areas surveyed outside of the active pit were below the limit of $1 \mathrm{mR} / \mathrm{h}$ at $0.9 \mathrm{~m}$, as specified by the RWMC Project Directives. ${ }^{19}$ The $1-\mathrm{mR} / \mathrm{h}$ criterion at $0.9 \mathrm{~m}$ ensures that personnel are not subjected to significant radiation exposure.

Background radiation levels $(0.008 \mathrm{mR} / \mathrm{h})$ were exceeded in several locations. The locations of these areas were documented and will be surveyed again in the future. With the exception of the area around the active pit, the highest reading noted in both surveys was $0.90 \mathrm{mR} / \mathrm{h}$ at contact and $0.38 \mathrm{mR} / \mathrm{h}$ at $0.91 \mathrm{~m}$. This location was found along Soil Vault Row 7.

The elevated radiation levels shown on the sides of the active pit were a result of the waste added during 1994. No new areas were identified during either the spring or fall survey that had not already been identified in earlier surveys.

\section{Stationary Low-Power Reactor No. 1}

The SL-1 area location is shown in Figure 1. Results of the spring and fall surface radiation surveys of the SL-1 surplus area identified no areas that exceeded the action level of $20 \mathrm{mR} / \mathrm{h}$ gamma at or near contact.

\section{Organic-Moderated Reactor Experiment}

The OMRE survey was conducted using a new global positioning radiometric scanner (GPRS). This new system integrates a five-channel global positioning system with the vehicle-mounted plastic scintillation radiation monitor and a single-board 386 compatible computer (see Figure 61).

Nine areas exceeding background $(0.007 \mathrm{mR} / \mathrm{h})$ were identified during the annual surface radiation survey at OMRE (see Figure 62). None of these areas exceeded the action level of $1 \mathrm{mR} / \mathrm{h}$ at contact. All areas with elevated radiation levels were consistent with those found during previous area surveys. Many of these areas were close to or at the ambient background level. The highest reading was $0.74 \mathrm{mR} / \mathrm{h}$ at $0.91 \mathrm{~m}$ and was the only reading which exceeded twice the background.

\section{Groundwater}

The USGS routinely samples groundwater from monitoring wells located in and adjacent to the RWMC (see Figure 63). Immediately surrounding the RWMC are USGS Wells $87,88,89$, $90,117,119$, and 120 , which penetrate the SRPA aquifer approximately $180 \mathrm{~m}$ beneath the surface. USGS Well 92, located in the west central portion of the SDA, is used for collecting perched groundwater samples and monitoring the depth to perched water. In 1973, the well was sealed with expanding concrete at a dense basaltic zone about $65 \mathrm{~m}$ below the surface, so that perched water could accumulate. Due to the removal of water during sampling, the water level varies between 63.3 and $64.0 \mathrm{~m}$ below the surface. 

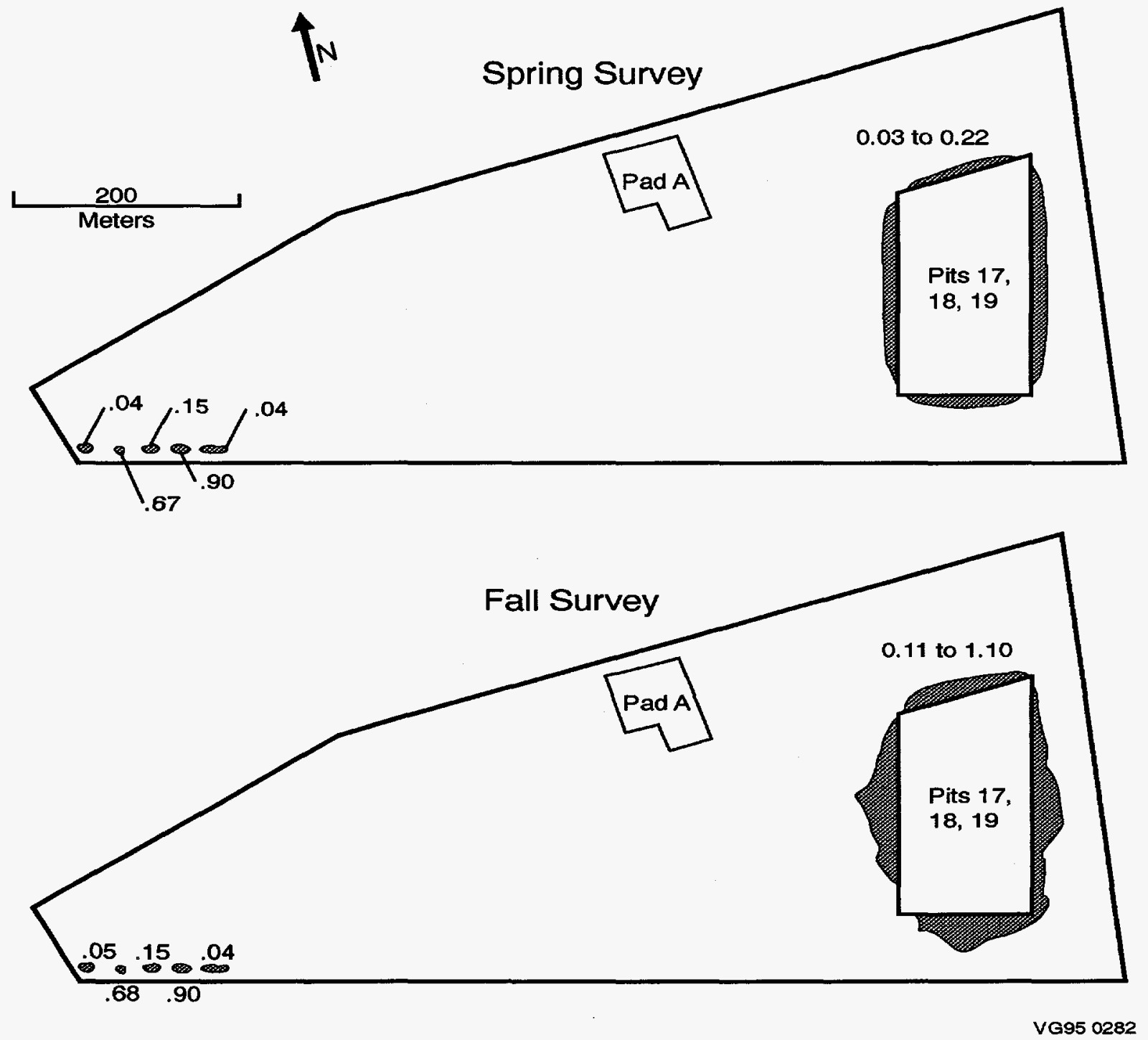

NOTE: All values are in $\mathrm{mR} / \mathrm{h}$.

Figure 60. Results of 1994 spring and fall RWMC surface radiation surveys. 


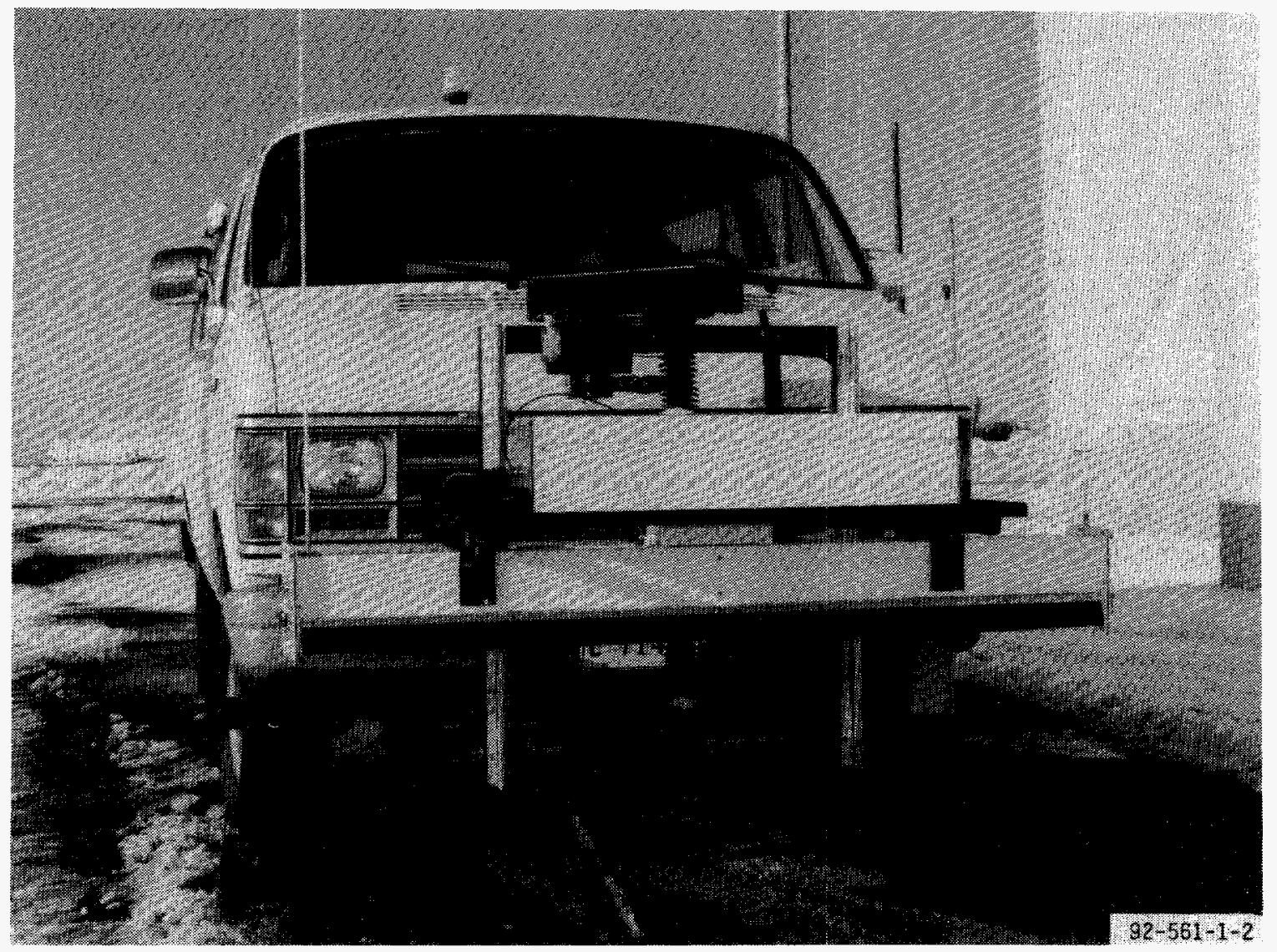

Figure 61. Global positioning system. 


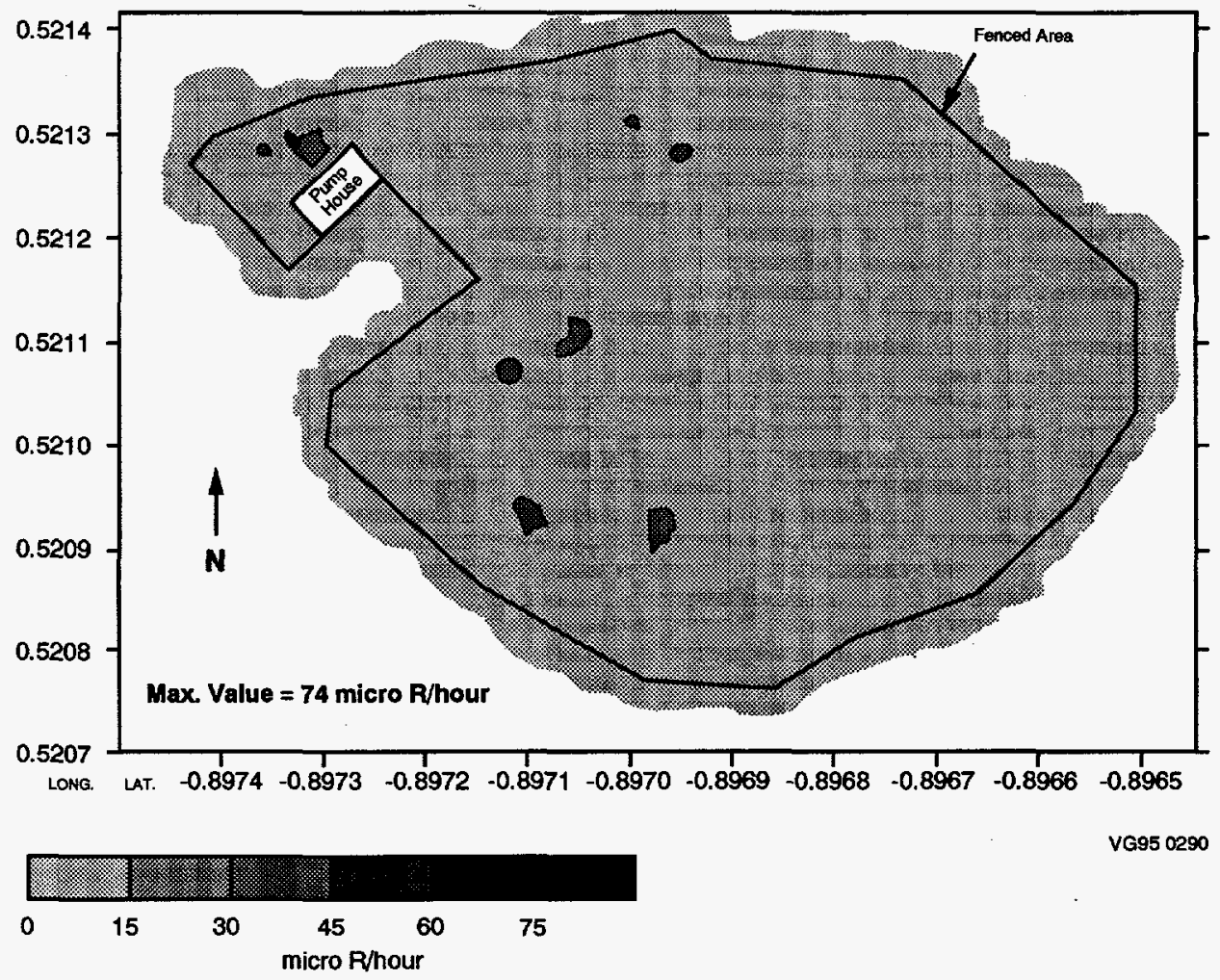

Figure 62. OMRE surface gamma radiation survey area and areas exceeding background levels.

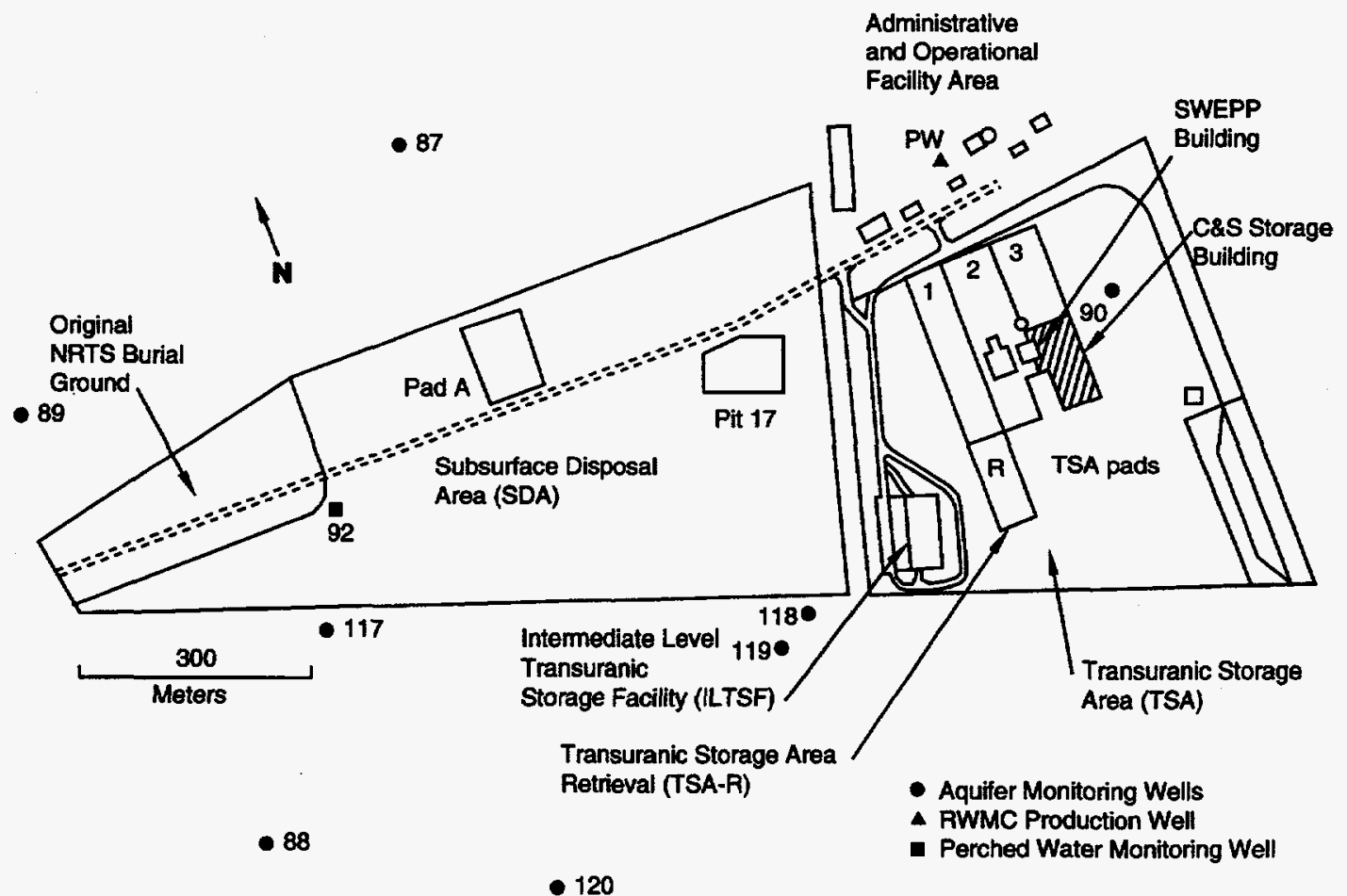

KL94 0082

Figure 63. USGS well locations. 
Each quarter the USGS measures specific conductance, $\mathrm{pH}$, temperature, and chloride, as well as $\mathrm{H}-3$ and $\mathrm{Sr}-90$. During 1994, samples from Wells $87,88,89,90,119$, and 120 were analyzed for gamma-emitting radionuclides (i.e., Co-60 and $\mathrm{Cs}-137)$, and TRU ( $\mathrm{Pu}-238, \mathrm{Pu}-239,-240$, and Am-241). The RWMC Production Well is sampled monthly for purgeable organic compounds while all other wells, except Well 92, are sampled quarterly. However, Well 92 was not sampled during 1994 for any constituents due to the limited amount of water in the well.

Since operations began at the INEL in the 1950 s, wastewater disposal at the INEL has increased the specific conductance of groundwater in the vicinity of INEL facilities. The background specific conductance of water from the SRPA at the INEL generally ranged from $178-860$ $\mu S / \mathrm{cm} .{ }^{20}$ This range was compared to the specific conductance measurements of water samples collected from wells at the RWMC in 1994 (see Table 6). These specific conductance measurements are comparable to those made in previous years.

During 1994, analyses for stable Na-22 were conducted (see Table 6). Water from some of the RWMC monitoring wells contained sodium concentrations higher than the background level of $10 \mathrm{mg} / \mathrm{L}$ (shown in Table 6). Sodium concentrations have fluctuated in water from these wells. One possible cause for these fluctuations is the method used to construct the wells. During construction, the wells were pressure-grouted to prevent water from cascading from perched zones down to the SRPA. The grout mixture could contribute to higher sodium concentrations.
The chloride concentration (see Table 6) also was above background levels $(8-15 \mathrm{mg} / \mathrm{L})$ but well below the secondary maximum contaminant level (MCL), which is $250 \mathrm{mg} / \mathrm{L}$ for chloride. The elevated chloride concentrations may be attributed to the same cause as the high sodium concentrations. Both the chloride and sodium concentrations are comparable to concentrations from previous years at these well locations.

Approximately $330,000 \mathrm{~L}$ of organic waste were disposed prior to 1970 at the RWMC. ${ }^{21}$ These buried wastes included about $92,000 \mathrm{~L}$ of carbon tetrachloride, $148,000 \mathrm{~L}$ of lubricating oil, and about 95,000 L of other organic compounds, including trichloroethane, trichloroethylene, perchloroethylene, toluene, and benzene.

Table 7 shows the 1994 concentrations of volatile organic compounds (VOCs) at USGS monitoring wells. The 1994 results are comparable to previous data. No MCLs for VOCs or radiological constituents were exceeded during 1994.

The results of the gamma spectrometry analysis performed on well samples taken in 1994 showed no positive detections of any gamma-emitting radionuclide.

Tritium was detected in Wells 87 and 90 and in the RWMC Production Well (see Table 8). Other radionuclides were not detected in the wells in any quarter. The maximum concentrations of tritium in Wells 87, 90, and the RWMC Production Well were 1.1 E-6, 1.3 E-6, and $1.7 \mathrm{E}-6 \mu \mathrm{Ci} / \mathrm{mL}$, respectively, with a standard deviation of $0.2 \mathrm{E}-6 \mu \mathrm{Ci} / \mathrm{mL}$. These concentrations are well below the DCG for the public (less than $0.1 \%$ of the DCG, as shown in Appendix D, Table D-1). The source of the tritium is attributed to past disposal of wastewater from operations at the Idaho Chemical Processing Plant (ICPP) and Test Reactor Area (TRA) as reported by Orr and Cecil. ${ }^{20}$ 
Table 6. Results of chemical analyses of subsurface water at the RWMC in 1994.

\begin{tabular}{|c|c|c|c|c|}
\hline \multirow[b]{2}{*}{ Well } & \multirow[b]{2}{*}{ Month Sampled } & \multirow{2}{*}{$\begin{array}{c}\text { Specific } \\
\text { Conductance } \\
\mu S / \mathrm{cm}\end{array}$} & \multicolumn{2}{|c|}{ Concentration $(\mathrm{mg} / \mathrm{L})$} \\
\hline & & & $\mathrm{Cl}^{-}$ & $\mathrm{Na}^{+}$ \\
\hline \multirow[t]{4}{*}{87} & January & 351 & 13 & - $^{\mathrm{a}}$ \\
\hline & April & 360 & 13 & 9.6 \\
\hline & July & 354 & 13 & - \\
\hline & October & 353 & 14 & 10 \\
\hline \multirow[t]{4}{*}{88} & January & 589 & 93 & - \\
\hline & May & 569 & 81 & 44 \\
\hline & July & 580 & 79 & - \\
\hline & September & 571 & - & 45 \\
\hline \multirow[t]{4}{*}{89} & January & 386 & 39 & - \\
\hline & May & 384 & 39 & - \\
\hline & July & 384 & 39 & - \\
\hline & October & 382 & 37 & 20 \\
\hline \multirow[t]{2}{*}{90} & January & 361 & 13 & - \\
\hline & May & 363 & 14 & - \\
\hline \multirow[t]{3}{*}{117} & April & 275 & 13 & 9.6 \\
\hline & July & 282 & 13 & - \\
\hline & October & 273 & 13 & 10 \\
\hline \multirow[t]{4}{*}{119} & January & 281 & 9.6 & - \\
\hline & April & 276 & 9.4 & 11 \\
\hline & July & 281 & 9.5 & - \\
\hline & October & 275 & 9.2 & 11 \\
\hline \multirow[t]{4}{*}{120} & January & 440 & - & - \\
\hline & April & 436 & 23 & 75 \\
\hline & July & 433 & 22 & - \\
\hline & October & 430 & 20 & 25 \\
\hline
\end{tabular}


Table 7. Concentrations $(\mu \mathrm{g} / \mathrm{L})$ of selected volatile organic compounds in groundwater.

\begin{tabular}{|c|c|c|c|c|c|c|c|c|c|c|}
\hline $\begin{array}{c}\text { Well } \\
\text { Identifier }\end{array}$ & $\begin{array}{c}\text { Date } \\
\text { Sampled }\end{array}$ & $\begin{array}{l}\text { Carbon } \\
\text { Tetra- } \\
\text { chloride }\end{array}$ & Chloroform & $\begin{array}{c}1,1,1- \\
\text { Trichloro- } \\
\text { ethane }\end{array}$ & $\begin{array}{l}\text { Trichloro- } \\
\text { ethylene }\end{array}$ & $\begin{array}{l}\text { Tetrachlo- } \\
\text { roethylene }\end{array}$ & $\begin{array}{l}\text { Dichloro- } \\
\text { difluoro- } \\
\text { methane }\end{array}$ & Toluene & $\begin{array}{l}1,1- \\
\text { Dichloro- } \\
\text { ethane }\end{array}$ & $\begin{array}{c}1,1- \\
\text { Dichloro- } \\
\text { ethylene }\end{array}$ \\
\hline \multirow[t]{4}{*}{87} & $1 / 94$ & 1.0 & $<0.2$ & 0.2 & 0.3 & $<0.2$ & $<0.2$ & $<0.2$ & $<0.2$ & $<0.2$ \\
\hline & $4 / 94$ & 1.3 & $<0.2$ & $<0.2$ & 0.4 & $<0.2$ & $<0.2$ & $<0.2$ & $<0.2$ & $<0.2$ \\
\hline & $7 / 94$ & 1.4 & $<0.2$ & $<0.2$ & 0.4 & $<0.2$ & $<0.2$ & $<0.2$ & $<0.2$ & $<0.2$ \\
\hline & $10 / 94$ & 1.3 & $<0.2$ & $<0.2$ & 0.4 & $<0.2$ & $<0.2$ & $<0.2$ & $<0.2$ & $<0.2$ \\
\hline \multirow[t]{4}{*}{$88^{\mathrm{a}}$} & $1 / 94$ & 1.5 & 0.5 & 0.2 & 0.8 & $<0.2$ & $<0.2$ & $<0.2$ & $<0.2$ & $<0.2$ \\
\hline & $5 / 94$ & 1.2 & 0.5 & 0.2 & 0.6 & $<0.2$ & $<0.2$ & $<0.2$ & $<0.2$ & $<0.2$ \\
\hline & $7 / 94$ & 1.6 & 0.4 & 0.2 & 0.9 & $<0.2$ & $<0.2$ & $<0.2$ & $<0.2$ & $<0.2$ \\
\hline & $9 / 94$ & 1.7 & 0.5 & 0.2 & 0.8 & $<0.2$ & $<0.2$ & $<0.2$ & $<0.2$ & $<0.2$ \\
\hline \multirow[t]{4}{*}{89} & $2 / 94$ & $ـ^{b}$ & - & - & - & - & - & - & - & - \\
\hline & $5 / 94$ & $<0.2$ & $<0.2$ & 0.2 & $<0.2$ & $<0.2$ & $<0.2$ & $<0.2$ & $<0.2$ & $<0.2$ \\
\hline & $7 / 94$ & 一 & - & - & - & - & - & - & - & - \\
\hline & $10 / 94$ & $<0.2$ & $<0.2$ & $<0.2$ & $<0.2$ & $<0.2$ & $<0.2$ & $<0.2$ & $<0.2$ & $<0.2$ \\
\hline \multirow[t]{2}{*}{90} & $5 / 94$ & 1.2 & $<0.2$ & 0.3 & 0.5 & $<0.2$ & $<0.2$ & $<0.2$ & $<0.2$ & $<0.2$ \\
\hline & $10 / 94$ & 1.5 & $<0.2$ & 0.3 & 0.5 & $<0.2$ & $<0.2$ & $<0.2$ & $<0.2$ & $<0.2$ \\
\hline 92 & $11 / 94$ & - & - & - & - & - & - & - & - & - \\
\hline \multirow[t]{3}{*}{117} & $4 / 94$ & $<0.2$ & $<0.2$ & $<0.2$ & $<0.2$ & $<0.2$ & $<0.2$ & $<0.2$ & $<0.2$ & $<0.2$ \\
\hline & $7 / 94$ & - & - & - & - & - & - & - & - & - \\
\hline & $10 / 94$ & $<0.2$ & $<0.2$ & $<0.2$ & $<0.2$ & $<0.2$ & $<0.2$ & $<0.2$ & $<0.2$ & $<0.2$ \\
\hline \multirow[t]{4}{*}{119} & $1 / 94$ & - & - & - & - & - & - & - & - & - \\
\hline & $4 / 94$ & $<0.2$ & $<0.2$ & $<0.2$ & $<0.2$ & $<0.2$ & $<0.2$ & $<0.2$ & $<0.2$ & $<0.2$ \\
\hline & 7/94 & - & - & - & - & - & - & - & - & - \\
\hline & $10 / 94$ & $<0.2$ & $<0.2$ & $<0.2$ & $<0.2$ & $<0.2$ & $<0.2$ & $<0.2$ & $<0.2$ & $<0.2$ \\
\hline
\end{tabular}


Table 7. (continued).

\begin{tabular}{|c|c|c|c|c|c|c|c|c|c|c|}
\hline $\begin{array}{c}\text { Well } \\
\text { Identifier }\end{array}$ & $\begin{array}{c}\text { Date } \\
\text { Sampled }\end{array}$ & $\begin{array}{l}\text { Carbon } \\
\text { Tetra- } \\
\text { chloride }\end{array}$ & Chloroform & $\begin{array}{c}1,1,1- \\
\text { Trichloro- } \\
\text { ethane }\end{array}$ & $\begin{array}{l}\text { Trichloro- } \\
\text { ethylene }\end{array}$ & $\begin{array}{l}\text { Tetrachlo- } \\
\text { roethylene }\end{array}$ & $\begin{array}{l}\text { Dichloro- } \\
\text { difluoro- } \\
\text { methane }\end{array}$ & Toluene & $\begin{array}{c}1,1- \\
\text { Dichloro- } \\
\text { ethane }\end{array}$ & $\begin{array}{c}1,1- \\
\text { Dichloro- } \\
\text { ethylene }\end{array}$ \\
\hline \multirow[t]{4}{*}{120} & $1 / 94$ & - & - & - & - & - & - & - & - & - \\
\hline & $4 / 94$ & 0.7 & $<0.2$ & $<0.2$ & $<0.2$ & $<0.2$ & $<0.2$ & $<0.2$ & $<0.2$ & $<0.2$ \\
\hline & $7 / 94$ & 0.5 & $<0.2$ & 0.2 & $<0.2$ & $<0.2$ & $<0.2$ & $<0.2$ & $<0.2$ & $<0.2$ \\
\hline & $10 / 94$ & 0.6 & $<0.2$ & 0.2 & $<0.2$ & $<0.2$ & $<0.2$ & $<0.2$ & $<0.2$ & $<0.2$ \\
\hline \multirow{12}{*}{$\begin{array}{l}\text { RWMC } \\
\text { Production } \\
\text { Well }\end{array}$} & $1 / 94$ & 2.3 & 0.3 & 0.4 & 1.3 & $<0.2$ & $<0.2$ & $<0.2$ & $<0.2$ & $<0.2$ \\
\hline & $2 / 94$ & 3.0 & 0.4 & 0.5 & 1.7 & 0.2 & $<0.2$ & $<0.2$ & $<0.2$ & $<0.2$ \\
\hline & $3 / 94$ & 3.0 & 0.4 & 0.5 & 1.6 & 0.2 & $<0.2$ & $<0.2$ & $<0.2$ & $<0.2$ \\
\hline & $4 / 94$ & 3.0 & 0.4 & 0.5 & 1.5 & $<0.2$ & $<0.2$ & $<0.2$ & $<0.2$ & $<0.2$ \\
\hline & $5 / 94$ & 2.7 & 0.4 & 0.4 & 1.4 & $<0.2$ & $<0.2$ & $<0.2$ & $<0.2$ & $<0.2$ \\
\hline & $6 / 94$ & 3.0 & 0.4 & 0.5 & 1.4 & $<0.2$ & $<0.2$ & $<0.2$ & $<0.2$ & $<0.2$ \\
\hline & $7 / 94$ & 2.6 & 0.3 & 0.4 & 1.2 & $<0.2$ & $<0.2$ & $<0.2$ & $<0.2$ & $<0.2$ \\
\hline & $8 / 94$ & 2.6 & 0.3 & 0.4 & 1.2 & $<0.2$ & $<0.2$ & $<0.2$ & $<0.2$ & $<0.2$ \\
\hline & $9 / 94$ & 2.9 & 0.3 & 0.5 & 1.3 & $<0.2$ & $<0.2$ & $<0.2$ & $<0.2$ & $<0.2$ \\
\hline & $10 / 94$ & 2.6 & 0.3 & 0.4 & 1.3 & $<0.2$ & $<0.2$ & $<0.2$ & $<0.2$ & $<0.2$ \\
\hline & $11 / 94$ & 3.1 & 0.5 & 0.5 & 1.5 & $<0.2$ & $<0.2$ & $<0.2$ & $<0.2$ & $<0.2$ \\
\hline & $12 / 94$ & 4.7 & 0.6 & 0.7 & 1.8 & 0.2 & $<0.2$ & $<0.2$ & $<0.2$ & $<0.2$ \\
\hline
\end{tabular}

a. Tests specific to pumps and instrumentation were conducted on well 88 during Febuary 1992. The results of these tests are reported in a USGS report titled Purgeable Organic Compounds in the Ground Water at the Idaho National Engineering Laboratory, 1990-1992.20

b. No samples were collected. 
Table 8. Results of radiochemical analyses of RWMC subsurface water.

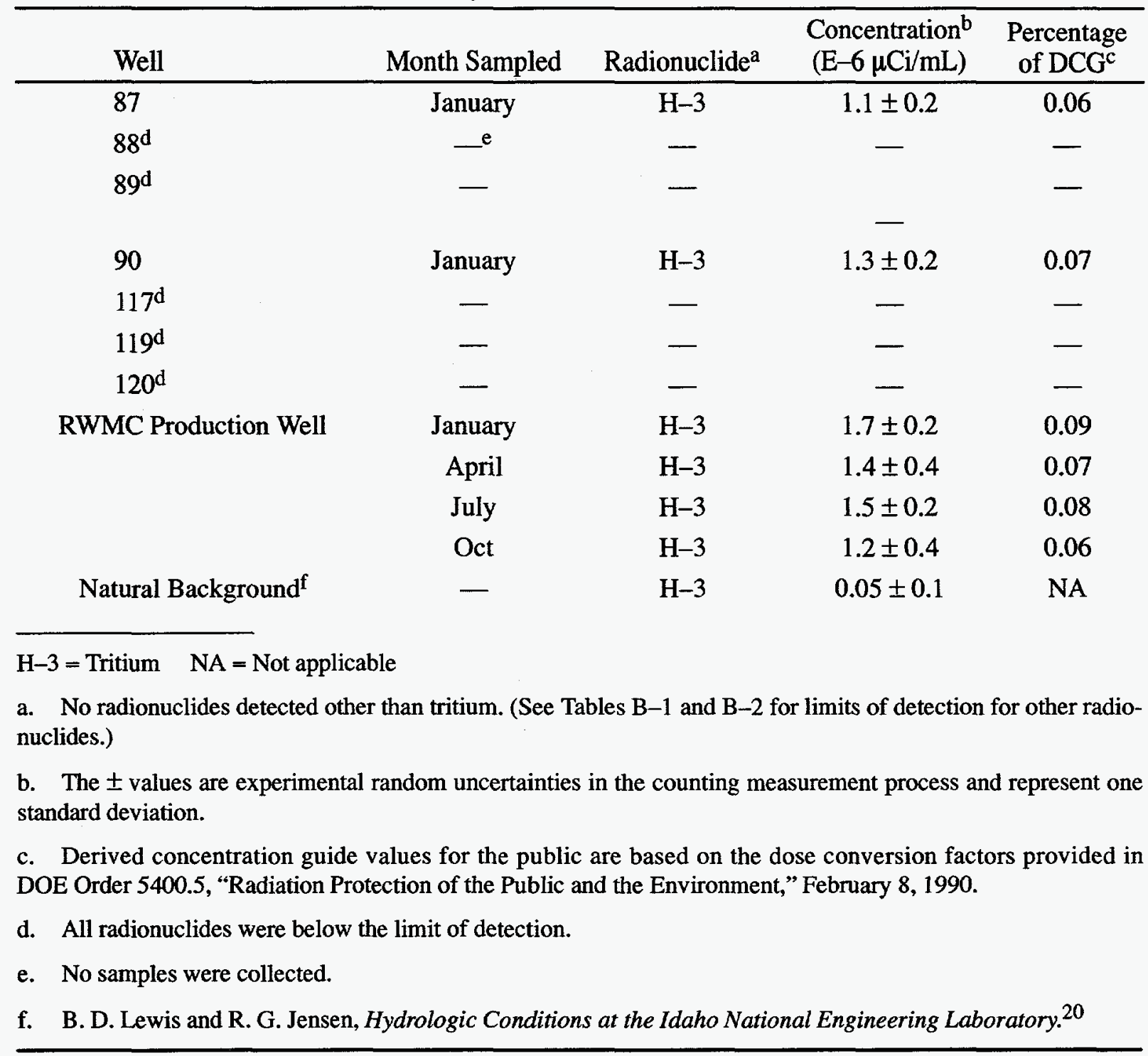




\section{REFERENCES}

1. K. L. Clawson, G. E. Start, and N. R. Ricks, Climatography of the Idaho National Engineering Laboratory, 2nd Edition, DOE/ID-12118, December 1989.

2. R. McBride, W. R. French, A. H. Dahl, and J. E. Detmer, Vegetation Types and Surface Soils of the Idaho National Engineering Laboratory Site, IDO-12084, 1978.

3. L. E. Adams, D. H. Janke, and P. T. Dickman, Annual Report-1978 Environmental Surveillance Report of the INEL Radioactive Waste Management Complex, TREE-1357, 1979.

4. C. R. Groves, The Ecology of Small Mammals on the Subsurface Disposal Area Idaho National Engineering Laboratory, M.S. Thesis, Idaho State University, 1981.

5. Department of Energy, "General Environmental Protection Program," DOE Order 5400.1, November $9,1988$.

6. Department of Energy, "Radioactive Waste Management," DOE Order 5820.2A, September 26, 1988.

7. O. D. Markham, K. W. Puphal, and T. D. Filer, "Plutonium and Americium Contamination Near a Transuranic Storage Area in Southeastern Idaho," Journal of Environmental Quality, 7, July/ September 1978, pp. 422-428.

8. EG\&G Idaho, Inc., Quality Program Plan for Environmental Monitoring, QPP-029, June 6, 1994.

9. EG\&G Idaho, Inc., Environmental Surveillance Handbook, "Radiological and Environmental Surveillance Program Plan for Waste Management Facilities," July 1994.

10. EG\&G Idaho, Inc., 1992, Monitoring Activities Review of the Radiological Environmental Surveillance Program, EGG-ESQ-10167.

11. Environmental Regulatory Guide for Radiological Effluent Monitoring and Environmental Surveillance at U.S. Department of Energy Installations, DOE/EH-0173T, January 1991.

12. EG\&G Idaho, Inc., Modifications to RWMC Air Monitoring Activities Recommended by the Monitoring Activities Review, August 23, 1983.

13. Department of Energy, "Radiation Protection of the Public and the Environment," DOE Order 5400.5, January 7, 1993.

14. EG\&G Idaho, Inc., 1983c, Modifications to RWMC Soil Monitoring Activities Recommended by the Monitoring Activities Review, July 29, 1983.

15. EG\&G Idaho, Inc., 1989, Monitoring Activities Review of the Environmental Monitoring Program, EGG-ESQ-8406.

16. W. J. Arthur and O. D. Markham, Small Mammal Soil Burrowing as a Radionuclide Transport Vector at a Radioactive Waste Disposal Area in Southeastern Idaho, 1982.

17. W. J. Arthur, "Radionuclide Concentrations in Vegetation at a Solid Radioactive Disposal Area in Southeastern Idaho," Journal of Environmental Quality, 11, 1982, pp. 394-398. 
18. EG\&G Idaho, Inc., 1983d, Environmental Monitoring for the Waste Experimental Reduction Facility at the Idaho National Engineering Laboratory, RHB-132-83.

19. EG\&G Idaho, Inc., RWMC Project Directives, PD-RS-6.1, "Radiation and Contamination Control," January 10, 1995.

20. B. R. Orr and L. D. Cecil, Hydrologic Conditions and Distribution of Selected Chemical Constituents in Water, Snake River Plain Aquifer, Idaho National Engineering Laboratory, Idaho, 1986 to 1988, U.S. Geological Survey Water-Resources Investigations Report 91-4047, 1991.

21. L. J. Mann and L. L. Knobel, Purgeable Organic Compounds in Ground Water at the Idaho National Engineering Laboratory, Idaho, U.S. Geological Survey Open-File Report 87-776 (DOE/ID-22074), p 23, 1987. 
Appendix A

Quality Assurance

A-1 


$$
\text { A-2 }
$$




\section{Appendix A}

\section{Quality Assurance}

The objectives of the Quality Assurance (QA) Program for the Radiological Environmental Surveillance Program (RESP) activities at INEL Waste Management Facilities are to identify deficiencies in the sampling, measuring, and reporting processes so that corrective action can be taken, and to ensure that the results of the monitoring programs are valid.

Specific elements used to ensure that the objectives of the QA Program are met include:

- Organizational structure and responsibilities of managerial and program personnel

- Program description and objectives

- Program basis and design

- Documented procedures that describe the materials and equipment needed, specific precautions, prerequisites, and step-by-step sampling procedures for monitoring activities

- Data quality objectives

- Document-control processes for the preparation, revision, and approval of procedures

- Sample custody
- Maintenance of records pertaining to monitoring activities, such as planning documents, data sheets, sample results, and calibration records

- Proper calibration and preventive maintenance

- Data reduction and independent validation procedures

- Analysis of quality control samples (known standards, blank samples, split samples, replicates, and resubmitted samples) to assess accuracy and precision of monitoring results

- $\quad$ Planned and periodic audits, as well as self-assessments.

Radioanalytical laboratories provide acceptable results on quality control samples. Program personnel determine whether the analytical results for the control samples are acceptable. The sample media, activity in the quality control sample, and type of analysis are taken into consideration. Each set of known values and laboratory results receives individual consideration. Quality control samples representative of the RESP air particulate, soil, biota, and water samples are submitted for each sample type. Quality control samples, prepared by Lockheed Martin Idaho Technologies Radiochemistry, reflect the concentration levels found in environmental samples. 
A-4 
Appendix B

Detection Limits

B-1 
B-2 


\section{Appendix B}

\section{Detection Limits}

\section{RADIOCHEMICAL ANALYSIS DETECTION LIMITS}

Approximate detection limits of present methods used to analyze samples discussed in this report are listed in Tables B-1, B-2, and B-3 for a variety of radionuclides. The limits are based on sample sizes and forms as described in this report. Actual detection limits may vary depending upon background, yield, counting time, and sample volume.

The detection limits given in Table $\mathrm{B}-1$ in terms of activity per unit weight or volume are derived from the total activities in microcuries $(\mu \mathrm{Ci})$ that must be present in the sample aliquot. The detection limits are calculated under the following conditions: a counting time of 1000 minutes, a counting efficiency of about $25 \%$, a chemical yield of about $80 \%$, a clean detector and reagent blanks giving not more than about 5 counts in 1000 minutes in any given energy interval, and calculation performed according to the definition of detection limits given by $\mathrm{L}$. A. Currie. The detection limit equals $\left(2.71+4.66 \mathrm{~B}^{1 / 2}\right) /(\mathrm{t} \times \mathrm{E} \times \mathrm{Y} \times 2.22 \mathrm{E}+6)$ total $\mu \mathrm{Ci}$, where " $\mathrm{B}$ " is the total background and blank correction; " $t$ " is the counting time in minutes; " $E$ " is the counting efficiency as a fraction; " $Y$ " is the chemical yield as a fraction, and $2.22 \mathrm{E}+6$ is the $\mathrm{dpm} / \mu \mathrm{Ci}$. These absolute detection limits, in terms of total microcuries per sample, are about $3 \mathrm{E}-6$ for Sr-90 and about $3 \mathrm{E}-8$ for all alphaemitting nuclides. To determine the detection limits as activity concentration, as given in Table B-1, the absolute detection limits must be divided by the sample size taken for analysis. On samples, the activity found is divided by the actual sample size analyzed or reported in terms of total activity per sample.
Quality assurance samples are prepared as nearly identical to the real samples as possible. Air samples are simulated by spotting known quantities of activity as uniformly as possible over the filters and drying. Water solutions will contain known quantities of water-soluble tracer solutions.

For soils, 25-g samples of real, minus 200 mesh soil containing exactly known quantities of the radionuclides of interest homogeneously distributed throughout the sample are submitted, of which 10-g samples are analyzed. For dried vegetation and animal tissue, vegetation (avg wt $100 \mathrm{~g}$ ), mice (avg wt $55 \mathrm{~g}$ ), or ground squirrels (avg wt $85 \mathrm{~g}$ ) are spiked inhomogeneously with known quantities of radionuclides evaporated to dryness on about $100 \mathrm{mg}$ of clean, dry, minus 100-mesh soil to obtain quantitative transfer without wetting the samples. These samples may not be subdivided without complete dissolution because of their fundamental inhomogeneity.

Two levels of activity are necessary to check both the stated detection limits and to determine the accuracy and precision with which larger activities can be measured. The lower level consists of activities from about 1.5 to 5 times the stated absolute detection limit to maximize the influence of backgrounds, blanks, and incomplete separation of interferences from the sample on the net activity being measured. No attempt is made to verify stated detection limits by analysis of blank samples. This is due to the statistical uncertainty of a net result obtained by subtracting a reagent blank from a sample that is also blank. 
Table B-1. RESP samples for radiochemical analysis.

\begin{tabular}{|c|c|c|c|c|}
\hline Media & Sample Description & Method of Treatment & \multicolumn{2}{|c|}{$\begin{array}{r}\text { Detection Limits } \\
(\mu \mathrm{Ci} / \mathrm{g} \text { or } \mathrm{mL})\end{array}$} \\
\hline Air & $\begin{array}{l}\text { Sampled approxi- } \\
\text { mately at } 4 \text { cfm for } \\
2 \text { weeks on Versapor } \\
1200 \text { filters, } 6 \text { filters } \\
\text { per quarter for a total of } \\
\sim 1.7 \mathrm{E}+10 \mathrm{cc} \text { of air. }\end{array}$ & $\begin{array}{l}\text { Dry ash, dissolve and } \\
\text { analyze the total sample } \\
\text { of } 6 \text { filters. }\end{array}$ & $\begin{array}{l}\mathrm{Sr}-90 \\
\mathrm{Pu}-238 \\
\mathrm{Pu}-239 \\
\mathrm{Am}-241\end{array}$ & $\begin{array}{l}3.5 \mathrm{E}-17 \\
2 \mathrm{E}-18 \\
2 \mathrm{E}-18 \\
2 \mathrm{E}-18\end{array}$ \\
\hline Water & $\begin{array}{l}\text { 4-L collapsible poly- } \\
\text { ethylene container } \\
\text { containing } 25 \mathrm{~mL} \text { of } \\
\text { conc. } \mathrm{HNO}_{3} \text { and } 2 \\
\text { Whatman ashless filter } \\
\text { tablets for } 4000 \mathrm{~mL} \\
\text { water. }\end{array}$ & $\begin{array}{l}\text { Separate and dissolve pa- } \\
\text { per pulp, reconstitute } \\
\text { sample, and boil down to } \\
100 \mathrm{~mL} \text {. Analyze } 1 / 2 \\
\text { sample or } 2-\text { L equivalent. }\end{array}$ & $\begin{array}{l}\mathrm{Sr}-90 \\
\mathrm{Pu}-238 \\
\mathrm{Pu}-239 \\
\mathrm{Am}-241\end{array}$ & $\begin{array}{l}3 \mathrm{E}-10 \\
2 \mathrm{E}-11 \\
2 \mathrm{E}-11 \\
2 \mathrm{E}-11\end{array}$ \\
\hline Soil & $\begin{array}{l}\text { At least } 25 \mathrm{~g} \text { in appro- } \\
\text { priate container. Larg- } \\
\text { er quantities are per- } \\
\text { missible if convenient. }\end{array}$ & Analyze $10-\mathrm{g}$ sample. & $\begin{array}{l}\mathrm{Sr}-90 \\
\mathrm{Pu}-238 \\
\mathrm{Pu}-239 \\
\mathrm{Am}-241\end{array}$ & $\begin{array}{l}6 \mathrm{E}-8 \\
3 \mathrm{E}-9 \\
3 \mathrm{E}-9 \\
3 \mathrm{E}-9\end{array}$ \\
\hline Vegetation & $\begin{array}{l}16-\text { oz squat jar filled to } \\
\text { rim below threads (avg } \\
\text { wt } 150 \mathrm{~g} \text { ). }\end{array}$ & $\begin{array}{l}\text { Dry ash and dissolve the } \\
\text { total sample completely. } \\
\text { Analyze the equivalent of } \\
50 \mathrm{~g} \text { of original sample. }\end{array}$ & $\begin{array}{l}\mathrm{Sr}-90 \\
\mathrm{Pu}-238 \\
\mathrm{Pu}-239 \\
\mathrm{Am}-241\end{array}$ & $\begin{array}{l}1.2 \mathrm{E}-8 \\
6 \mathrm{E}-10 \\
6 \mathrm{E}-10 \\
6 \mathrm{E}-10\end{array}$ \\
\hline $\begin{array}{l}\text { Animal } \\
\text { Tissue }\end{array}$ & $\begin{array}{l}16-\mathrm{oz} \text { squat jar } \\
\text { containing } 10 \text { dried } \\
\text { deer mice, or } 1 \text { dried } \\
\text { ground squirrel (avg } \\
\text { wts: mice, } 170 \mathrm{~g} \text {; squir- } \\
\text { rel, } 100 \mathrm{~g} \text { ). }\end{array}$ & $\begin{array}{l}\text { Dry ash, dissolve, and } \\
\text { analyze the equivalent of } \\
50 \mathrm{~g} \text { of the original sam- } \\
\text { ple. }\end{array}$ & $\begin{array}{l}\mathrm{Sr}-90 \\
\mathrm{Pu}-238 \\
\mathrm{Pu}-239 \\
\mathrm{Am}-241\end{array}$ & $\begin{array}{l}1.2 \mathrm{E}-8 \\
6 \mathrm{E}-10 \\
6 \mathrm{E}-10 \\
6 \mathrm{E}-10\end{array}$ \\
\hline
\end{tabular}


Table B-2. RESP air, water, and soil samples for gamma spectrometry.

\begin{tabular}{|c|c|c|c|c|c|c|c|c|}
\hline \multirow[b]{2}{*}{ Radionuclides } & \multicolumn{2}{|c|}{ Air Filters } & \multicolumn{2}{|c|}{ Water Filtrate } & \multicolumn{2}{|c|}{ Water Insoluble } & \multicolumn{2}{|c|}{ Soils } \\
\hline & $\begin{array}{c}10^{-9} \\
\mathrm{pCi} / \mathrm{mL}\end{array}$ & $\begin{array}{c}\text { Total } \\
\mathrm{pCi}\end{array}$ & $\begin{array}{c}10^{-2} \\
\mathrm{pCi} / \mathrm{mL} \\
\end{array}$ & $\begin{array}{c}\text { Total } \\
\mathrm{pCi}\end{array}$ & $\begin{array}{c}10^{-4} \\
\mathrm{pCi} / \mathrm{mL}\end{array}$ & $\begin{array}{c}\text { Total } \\
\mathrm{pCi}\end{array}$ & $\mathrm{pCi} / \mathrm{g}$ & $\begin{array}{r}\text { Total } \\
\mathrm{pCi} \\
\end{array}$ \\
\hline $\mathrm{Sc}-46$ & 1 & 6 & 0.2 & 8 & 5 & 2 & 0.19 & 120 \\
\hline $\mathrm{Cr}-51$ & 5 & 3 & 1.1 & 44 & 20 & 8 & 0.5 & 300 \\
\hline $\mathrm{Mn}-54$ & 0.5 & 3 & 0.5 & 20 & 3 & 1.2 & 0.1 & 60 \\
\hline Co-58 & 0.5 & 3 & 0.09 & 3.6 & 4 & 1.6 & 0.1 & 60 \\
\hline $\mathrm{Fe}-59$ & 0.9 & 5.4 & 1.5 & 60 & 7 & 2.8 & 0.11 & 60 \\
\hline $\mathrm{Co}-60$ & 0.8 & 4.8 & 0.8 & 32 & 6 & 2.4 & 0.2 & 120 \\
\hline $\mathrm{Zn}-65$ & 1 & 6 & 0.5 & 20 & 15 & 6 & 0.2 & 120 \\
\hline $\mathrm{Nb}-94$ & 0.5 & 3 & 0.15 & 6 & 4 & 1.6 & 0.1 & 60 \\
\hline $\mathrm{Nb}-95$ & 0.5 & 3 & 0.11 & 4.4 & 80 & 32 & 0.1 & 60 \\
\hline $\mathrm{Zr}-95$ & 0.8 & 4.8 & 0.3 & 8 & 7 & 2.8 & 0.11 & 60 \\
\hline $\mathrm{Ru}-103$ & 0.7 & 4.2 & 0.16 & 6.4 & 4 & 1.6 & 0.1 & 60 \\
\hline $\mathrm{Ru}-106$ & 5 & 30 & 0.12 & 4.8 & 40 & 1.6 & 0.5 & 300 \\
\hline $\mathrm{Ag}-110 \mathrm{~m}$ & 0.5 & 3 & 0.15 & 6 & 5 & 20 & 0.1 & 60 \\
\hline $\mathrm{Sb}-124$ & 0.5 & 3 & 0.13 & 5.2 & 5 & 2 & 0.1 & 60 \\
\hline $\mathrm{Sb}-125$ & 1.5 & 9 & 0.3 & 12 & 15 & 6 & 0.2 & 120 \\
\hline $\mathrm{Cs}-134$ & 0.6 & 3.6 & 0.09 & 3.6 & 4 & 1.6 & 0.1 & 60 \\
\hline Cs-137 & 0.8 & 4.8 & 0.3 & 12 & 20 & 8 & 0.1 & 60 \\
\hline $\mathrm{Ce}-141$ & 0.9 & 5.4 & 0.3 & 12 & 6 & 2.4 & 0.1 & 60 \\
\hline $\mathrm{Ce}-144$ & 5 & 30 & 1.0 & 40 & 20 & 8 & 0.4 & 240 \\
\hline $\mathrm{Eu}-152$ & 2 & 12 & 0.5 & 20 & 15 & 6 & 0.2 & 120 \\
\hline $\mathrm{Eu}-154$ & 2 & 12 & 0.3 & 12 & 15 & 6 & 0.3 & 180 \\
\hline $\mathrm{Eu}-155$ & 2 & 12 & 0.8 & 32 & 10 & 4 & 0.3 & 180 \\
\hline Hf-181 & 0.6 & 3.6 & 0.12 & 4.8 & 6 & 2.4 & 0.1 & 60 \\
\hline $\mathrm{Ta}-182$ & 2 & 12 & 0.5 & 20 & 20 & 8 & 0.4 & 240 \\
\hline $\mathrm{Hg}-203$ & 0.5 & 3 & 0.15 & 6 & 2 & 0.8 & 0.1 & 60 \\
\hline Am-241 & 4 & 24 & 1.5 & 60 & 40 & 16 & 1.2 & 700 \\
\hline Gross Beta & 9.5 & & & & & & & \\
\hline Gross Alpha & 3.3 & & & & & & & \\
\hline
\end{tabular}


Table B-3. RESP biotic samples for gamma spectrometry.

\begin{tabular}{llllll} 
& \multicolumn{2}{c}{ Small Mammals } & & \multicolumn{2}{c}{ Vegetation } \\
\cline { 2 - 3 } Radionuclides & pCi/g & $\begin{array}{c}\text { Total } \\
\mathrm{pCi}\end{array}$ & & pCi/g & $\begin{array}{c}\text { Total } \\
\mathrm{pCi}\end{array}$ \\
\hline
\end{tabular}

\begin{tabular}{|c|c|c|c|c|}
\hline $\mathrm{Sc}-46$ & 0.2 & 12 & 0.07 & 12 \\
\hline $\mathrm{Cr}-51$ & 1.4 & 84 & 0.4 & 67 \\
\hline $\mathrm{Mn}-54$ & 0.18 & 11 & 0.05 & 8.4 \\
\hline $\mathrm{Co}-58$ & 0.3 & 18 & 0.05 & 8.4 \\
\hline $\mathrm{Fe}-59$ & 0.6 & 36 & 0.08 & 14 \\
\hline Co -60 & 1 & 60 & 0.1 & 17 \\
\hline $\mathrm{Zn}-65$ & 0.7 & 42 & 0.13 & 22 \\
\hline $\mathrm{Nb}-94$ & 0.2 & 12 & 0.05 & 8.4 \\
\hline $\mathrm{Nb}-95$ & 0.2 & 12 & 0.04 & 6.7 \\
\hline $\mathrm{Zr}-95$ & 0.3 & 18 & 0.07 & 12 \\
\hline$R u-103$ & 0.2 & 120 & 0.04 & 6.7 \\
\hline $\mathrm{Ru}-106$ & 2 & 12 & 0.5 & 84 \\
\hline $\mathrm{Ag}-110 \mathrm{~m}$ & 0.2 & 12 & 0.05 & 8.4 \\
\hline $\mathrm{Sb}-124$ & 0.2 & 12 & 0.04 & 6.7 \\
\hline $\mathrm{Sb}-125$ & 0.7 & 42 & 0.11 & 18 \\
\hline Cs-134 & 0.3 & 18 & 0.04 & 6.7 \\
\hline $\mathrm{Cs}-137$ & 1.3 & 78 & 0.13 & 22 \\
\hline $\mathrm{Ce}-141$ & 0.2 & 12 & 0.05 & 8.4 \\
\hline $\mathrm{Ce}-144$ & 1.1 & 66 & 0.16 & 27 \\
\hline $\mathrm{Eu}-152$ & 0.6 & 36 & 0.1 & 17 \\
\hline Eu-154 & 0.7 & 42 & 0.15 & 25 \\
\hline Eu-155 & 0.6 & 36 & 0.1 & 17 \\
\hline Hf-181 & 0.2 & 12 & 0.04 & 6.7 \\
\hline Ta-182 & 1.1 & 66 & 0.3 & 50 \\
\hline $\mathrm{Hg}-203$ & 0.16 & 96 & 0.05 & 8.4 \\
\hline Am-241 & 2 & 120 & 0.3 & 50 \\
\hline
\end{tabular}




\section{GAMMA SPECTROMETRIC ANALYSIS DETECTION LIMITS}

Tables B-2 and B-3 give absolute detection limits in the right-hand column for each sample type. The absolute detection limits are the total activities that should be present in the sample aliquot taken for analysis to be detected under the counting conditions described and calculated according to the definition of $L$. A. Currie. This definition is: detection limit $=\left(2.71+4.66 \mathrm{~B}^{1 / 2}\right)$ / ( $\mathrm{t} \times \mathrm{E} \times \mathrm{P} \times 2.22$ ) where " $\mathrm{B}$ " is the total correction in counts (Compton, background, blanks, etc., for the same counting time); "t" is the counting time in minutes; " $\mathrm{E}$ " is the counting efficiency as a fraction; "P" is the gamma-ray emission probability for the particular gamma ray being measured, and 2.22 is the $\mathrm{dpm} / \mathrm{pCi}$.

The figures in the left-hand column of each sample type give the same detection limits expressed in terms of $\mathrm{pCi} /$ unit weight or volume for the average sample sizes expected to be analyzed. Because the absolute detection limits must remain constant for a given counting time and efficiency, the detection limits in terms of concentrations become higher or lower as the sample size actually used in the analysis becomes smaller or larger. Shown in Table B-4 are descriptions of environmental monitoring samples for gamma spectrometry analysis and counting conditions for stated detection limits.

Quality assurance samples are prepared as identical to the real samples as possible. Air samples are simulated by spotting known quantities of activity as uniformly as possible over the filters and drying. Water solutions will contain known quantities of water-soluble tracers in dilute nitric acid. For soils, approximately $700 \mathrm{~g}$ of barren soil are spiked with soil standards containing exact known quantities of the radionuclides of interest homogeneously distributed throughout the sample. For dried vegetation and animal tissue, vegetation (avg wt 100 g), mice (avg wt $55 \mathrm{~g}$ ), and ground squirrels (avg wt $85 \mathrm{~g}$ ) are spiked as homogeneously as possible with exactly known quantities of tracer solutions evaporated to dryness on about $100 \mathrm{mg}$ of clean, dry minus 100 -mesh soil to enable quantitative transfer to the samples without wetting.

Two levels of activity are necessary to check both the stated detection limits and to determine the accuracy and precision with which larger activities can be measured. The lower level consists of activities from about 1.5 to 5 times the stated absolute detection limits to maximize the influence of backgrounds, blanks, and interferences from the sample on the net activity being measured. Specifically, no attempt is made to verify stated detection limits by analysis of blanks due to the large statistical uncertainties of net results obtained from subtracting blanks from samples that are also blank. The higher level consists of sufficient activity to permit relative standard deviations of 1 to $5 \%$ to minimize statistical uncertainties and make clearer the precision and accuracy being obtained. 
Table B-4. Description of RESP samples for gamma spectrometry analysis.

\begin{tabular}{|c|c|c|c|c|}
\hline \multirow[b]{2}{*}{ Radionuclides } & \multicolumn{2}{|c|}{ Small Mammals } & \multicolumn{2}{|c|}{ Vegetation } \\
\hline & $\mathrm{pCi} / \mathrm{g}$ & $\begin{array}{c}\text { Total } \\
\mathrm{pCi}\end{array}$ & $\mathrm{pCi} / \mathrm{g}$ & $\begin{array}{l}\text { Total } \\
\text { pCi }\end{array}$ \\
\hline $\mathrm{Sc}-46$ & 0.2 & 12 & 0.07 & 12 \\
\hline $\mathrm{Cr}-51$ & 1.4 & 84 & 0.4 & 67 \\
\hline $\mathrm{Mn}-54$ & 0.18 & 11 & 0.05 & 8.4 \\
\hline $\mathrm{Co}-58$ & 0.3 & 18 & 0.05 & 8.4 \\
\hline $\mathrm{Fe}-59$ & 0.6 & 36 & 0.08 & 14 \\
\hline $\mathrm{Co}-60$ & 1 & 60 & 0.1 & 17 \\
\hline $\mathrm{Zn}-65$ & 0.7 & 42 & 0.13 & 22 \\
\hline $\mathrm{Nb}-94$ & 0.2 & 12 & 0.05 & 8.4 \\
\hline $\mathrm{Nb}-95$ & 0.2 & 12 & 0.04 & 6.7 \\
\hline $\mathrm{Zr}-95$ & 0.3 & 18 & 0.07 & 12 \\
\hline $\mathrm{Ru}-103$ & 0.2 & 120 & 0.04 & 6.7 \\
\hline $\mathrm{Ru}-106$ & 2 & 12 & 0.5 & 84 \\
\hline $\mathrm{Ag}-110 \mathrm{~m}$ & 0.2 & 12 & 0.05 & 8.4 \\
\hline $\mathrm{Sb}-124$ & 0.2 & 12 & 0.04 & 6.7 \\
\hline $\mathrm{Sb}-125$ & 0.7 & 42 & 0.11 & 18 \\
\hline Cs-134 & 0.3 & 18 & 0.04 & 6.7 \\
\hline Cs-137 & 1.3 & 78 & 0.13 & 22 \\
\hline $\mathrm{Ce}-141$ & 0.2 & 12 & 0.05 & 8.4 \\
\hline $\mathrm{Ce}-144$ & 1.1 & 66 & 0.16 & 27 \\
\hline $\mathrm{Eu}-152$ & 0.6 & 36 & 0.1 & 17 \\
\hline $\mathrm{Eu}-154$ & 0.7 & 42 & 0.15 & 25 \\
\hline $\mathrm{Eu}-155$ & 0.6 & 36 & 0.1 & 17 \\
\hline Hf-181 & 0.2 & 12 & 0.04 & 6.7 \\
\hline $\mathrm{Ta}-182$ & 1.1 & 66 & 0.3 & 50 \\
\hline $\mathrm{Hg}-203$ & 0.16 & 96 & 0.05 & 8.4 \\
\hline Am-241 & 2 & 120 & 0.3 & 50 \\
\hline
\end{tabular}


Appendix C

Statistical Analysis Methods 
C-2 


\section{Appendix C}

\section{Statistical Analysis Methods}

\section{General}

This appendix summarizes the statistical methods used in the analysis of RESP airborne particulate and penetrating radiation data presented in the text of this report. Specifically, this method is used for long term trend determinations and for determining differences between groupings (i.e., by monitor type, by facility, or by season) of data are addressed. These methods are detailed in Blackwood. ${ }^{1}$

\section{Data Pretreatment and Validation}

Prior to using data for comparative purposes, data are prescreened to ensure no gross data errors occur, such as transcription errors, missing values, out of range data points, and data points that do not meet other specific criteria. Initial screening includes eliminating data from instruments not meeting minimum required operating characteristics as specified in the data quality objectives.

Once the basic checks for errors and operating criteria are complete, the data are screened for outliers. Graphical techniques (e.g., probability plots, stem and leaf plots, box plots, and other exploratory data analysis techniques) are the primary tools used for detecting potential data outliers. In cases where outliers are traceable to a specific error, a corrected value may be used to replace the outlier. If no correction is possible, then the point is deleted from the data set. Rarely are outliers with unattributable causes eliminated from the data set. Such outliers may be truly accurate data measurements indicative of unusual but important phenomena. In these cases, two sets of analyses are performed with the outliers, one with and one without providing results that can be compared.

\section{Trend Analysis}

To visually evaluate long term trends, cumulative data are presented graphically. For RESP gross alpha and gross beta air data, concentration data for specific locations are plotted over the year of interest. Four concentration versus time plots are provided, separated by monitor and analysis type. Within each plot, data are smoothed using polynomial smoothing, and lines indicating the polynomial fit to the data are presented to provide a general indication of the trend in concentrations over the year.

For TLD data, cumulative six-month exposure data from specific locations, with background (or distant community) data excluded, are plotted over time. All historical data are smoothed and plotted on a logarithmic scale to give an indication of the trend over time.

\section{Comparisons Between Groupings}

\section{Penetrating Radiation Data from TLDs}

Differences in yearly TLD data, either seasonally or by facility location, are analyzed using the nonparametric Kruskal-Wallis test for differences in medians. Nonparametric analyses are performed since the data are not expected to follow a normal distribution. Changes among groups are considered to be statistically significant if the p-value, associated with the null hypothesis that the different samples in the groupings were from the same distribution or from distributions with the same median, is less than 0.05 .

The statistical significance of changes seen in median exposure values from the previous year to the current year is determined by facility. Facility groupings consist of background (or distant community) data, as well as individual RESP locations. Since TLDs are changed out every six 
months, the significance of the differences in median seasonal exposure values (either spring or fall) is also of interest.

Box and Whisker plots are used to graphically display the differences in median values between groups (either by facility or season). For each grouping, the median value is shown on the Box and Whisker plots, along with a box indicating the 25th to 75 th percentile range. The whiskers on the plots indicate the (non-outlier) minimum and maximum values within each grouping. For the Box and Whisker plots, outliers are defined at those data values greater than 1.5 times the range of the box.

\section{Airborne (Gross Alpha and Gross Beta) Data}

Differences in year-to-year median concentrations for facility groupings of airborne data are also analyzed using the Kruskal-Wallis test for differences in medians. Data from the current year are grouped by facility for each contaminant and monitor type (i.e., gross alpha or gross beta and $\mathrm{PM}_{10}$ or SP monitor) and compared to the same groupings using data from the previous year. Differences in groupings are also graphically displayed using the Box and Whisker plots discussed above. 


\section{REFERENCES}

1. Blackwood, L. G., Statistical Analysis Methods for Data From the EG\&G Idaho Environmental Unit Radiological Environmental Surveillance Program, EG\&G Idaho, Inc., EGGRAAM-10785, 1993. 
C-6 
Appendix D

Environmental Standards

D-1 


$$
\text { D-2 }
$$




\section{Appendix D}

\section{Environmental Standards}

\section{RADIOLOGICAL MONITORING AT WASTE MANAGEMENT FACILITIES}

Radionuclide concentrations in air and groundwater samples collected at the RWMC, the WERF, and the MWSF are compared with DCG values for air and water. ${ }^{1}$ The DCG values listed are provided as reference values for conducting radiological protection programs at operational DOE facilities and sites. The DCG values for internal exposure are based on a committed effective dose equivalent (EDE) of $100 \mathrm{mrem}$ for the radionuclide taken into the body by ingestion or inhalation during one year. Radionuclide concentrations in soil samples are compared to environmental concentration guidelines for soils, based on an onsite "homesteader."

Table D-1 lists applicable DCGs. The DCGs represent the concentrations of radioactivity in air inhaled or water ingested continuously during a year that resulted in a 100-mrem, 50-year committed EDE. The DCGs are used as a point of reference only. Comparison of individual measurements to the DCGs gives the maximum dose a person could receive at the location where the sample was collected, given the following two assumptions: (1) the concentration was at the DCG level continuously for the entire year, and (2) the person receiving the exposure was at that location for the entire year, continually drinking the water or inhaling the air. In practice, DCGs are rarely, if ever, exceeded for even a short period during the year. In addition, the radionuclide concentration at any area accessible to the public will be even less due to the dispersion from the facility boundary (where the sample was taken) to the site boundary (the closest location where the public has unrestricted access).

Table D-2 lists environmental concentration guidelines for the radionuclides in soil that are most likely to be found in environmental samples collected at the RWMC. The concentration guides in Table D-2 are based on a homestead scenario. This scenario considers the radiation dose to the homesteader from inhalation and ingestion of radionuclides, as well as external radiation. Since the hypothetical homesteader is living on the contaminated area, this scenario results in very conservative concentration guides. The homestead scenario provides overestimates of the actual doses that would be received by off-homestead individuals from waste radionuclides in soil at the RWMC. 
Table D-1. Derived concentration guides.

\begin{tabular}{|c|c|c|}
\hline \multirow[b]{2}{*}{ Radionuclide } & \multicolumn{2}{|c|}{ DCGs for the Public ${ }^{a, b}$} \\
\hline & $\begin{array}{l}\text { DCG for Air } \\
(\mu \mathrm{Ci} / \mathrm{mL})\end{array}$ & $\begin{array}{l}\text { DCG for Water } \\
(\mu \mathrm{Ci} / \mathrm{mL})\end{array}$ \\
\hline $\mathrm{H}-3$ & $1 \mathrm{E}-7$ & $2 \mathrm{E}-3$ \\
\hline $\mathrm{Sc}-46$ & $6 \mathrm{E}-10$ & $2 \mathrm{E}-5$ \\
\hline $\mathrm{Cr}-51$ & $5 \mathrm{E}-8$ & $1 \mathrm{E}-3$ \\
\hline$M n-54$ & $2 \mathrm{E}-9$ & $5 \mathrm{E}-5$ \\
\hline $\mathrm{Co}-58$ & $2 \mathrm{E}-9$ & $4 \mathrm{E}-5$ \\
\hline Fe-59 & $8 \mathrm{E}-10$ & $2 \mathrm{E}-5$ \\
\hline Co- 60 & $8 \mathrm{E}-11$ & $5 \mathrm{E}-6$ \\
\hline $\mathrm{Zn}-65$ & $6 \mathrm{E}-10$ & $9 E-6$ \\
\hline $\mathrm{Sr}-90$ & $9 \mathrm{E}-12$ & $1 \mathrm{E}-6$ \\
\hline $\mathrm{Nb}-95$ & $3 \mathrm{E}-9$ & $6 \mathrm{E}-5$ \\
\hline $\mathrm{Zr}-95$ & $6 \mathrm{E}-10$ & $4 \mathrm{E}-5$ \\
\hline $\mathrm{Ru}-103$ & $2 \mathrm{E}-9$ & $5 \mathrm{E}-5$ \\
\hline Ru-106 & $3 \mathrm{E}-11$ & $6 \mathrm{E}-6$ \\
\hline $\mathrm{Ag}-110 \mathrm{~m}$ & $2 \mathrm{E}-10$ & $1 \mathrm{E}-5$ \\
\hline $\mathrm{Sb}-125$ & $1 \mathrm{E}-9$ & $5 \mathrm{E}-5$ \\
\hline $\mathrm{I}-129$ & $7 \mathrm{E}-11$ & $5 \mathrm{E}-7$ \\
\hline $\mathrm{I}-131$ & $4 E-10$ & $3 E-6$ \\
\hline Cs-134 & $2 \mathrm{E}-10$ & $2 \mathrm{E}-6$ \\
\hline Cs -137 & $4 E-10$ & $3 \mathrm{E}-6$ \\
\hline $\mathrm{Ce}-141$ & $1 \mathrm{E}-9$ & $5 \mathrm{E}-5$ \\
\hline $\mathrm{Ce}-144$ & $3 \mathrm{E}-11$ & $7 \mathrm{E}-6$ \\
\hline $\mathrm{Eu}-152$ & $5 \mathrm{E}-11$ & $2 \mathrm{E}-5$ \\
\hline Eu-154 & $5 \mathrm{E}-11$ & $2 \mathrm{E}-5$ \\
\hline $\mathrm{Ra}-226$ & $1 \mathrm{E}-12$ & $1 \mathrm{E}-7$ \\
\hline $\mathrm{Pu}-238$ & $3 \mathrm{E}-14$ & $4 \mathrm{E}-8$ \\
\hline $\mathrm{Pu}-239^{\mathrm{c}}$ & $2 \mathrm{E}-14$ & $3 \mathrm{E}-8$ \\
\hline Am-24l & $2 \mathrm{E}-14$ & $3 \mathrm{E}-8$ \\
\hline$U-235$ & $1 \mathrm{E}-13$ & $6 \mathrm{E}-7$ \\
\hline $\mathrm{U}-238$ & $1 \mathrm{E}-13$ & $6 \mathrm{E}-7$ \\
\hline Gross Alpha ${ }^{\mathfrak{c}}$ & $2 \mathrm{E}-14$ & \\
\hline Gross Beta ${ }^{c}$ & $9 \mathrm{E}-12$ & \\
\hline
\end{tabular}

a. This table contains the air and water DCGs based on concentrations that could be continuously inhaled or ingested, respectively, and do not exceed an effective dose equivalent of $100 \mathrm{mR} / \mathrm{yr}$.

b. DCGs apply to radionuclide concentrations in excess of those occurring naturally or due to fallout.

c. The DCGs of $\mathrm{Pu}-239$ and $\mathrm{Sr}-90$ are the most restrictive for alpha- and beta-emitting nuclides, respectively, and are appropriate to use for gross alpha and gross beta DCGs. 
Table D-2. Environmental concentration guidelines for common radionuclides found in environmental soil samples collected at the RWMC.

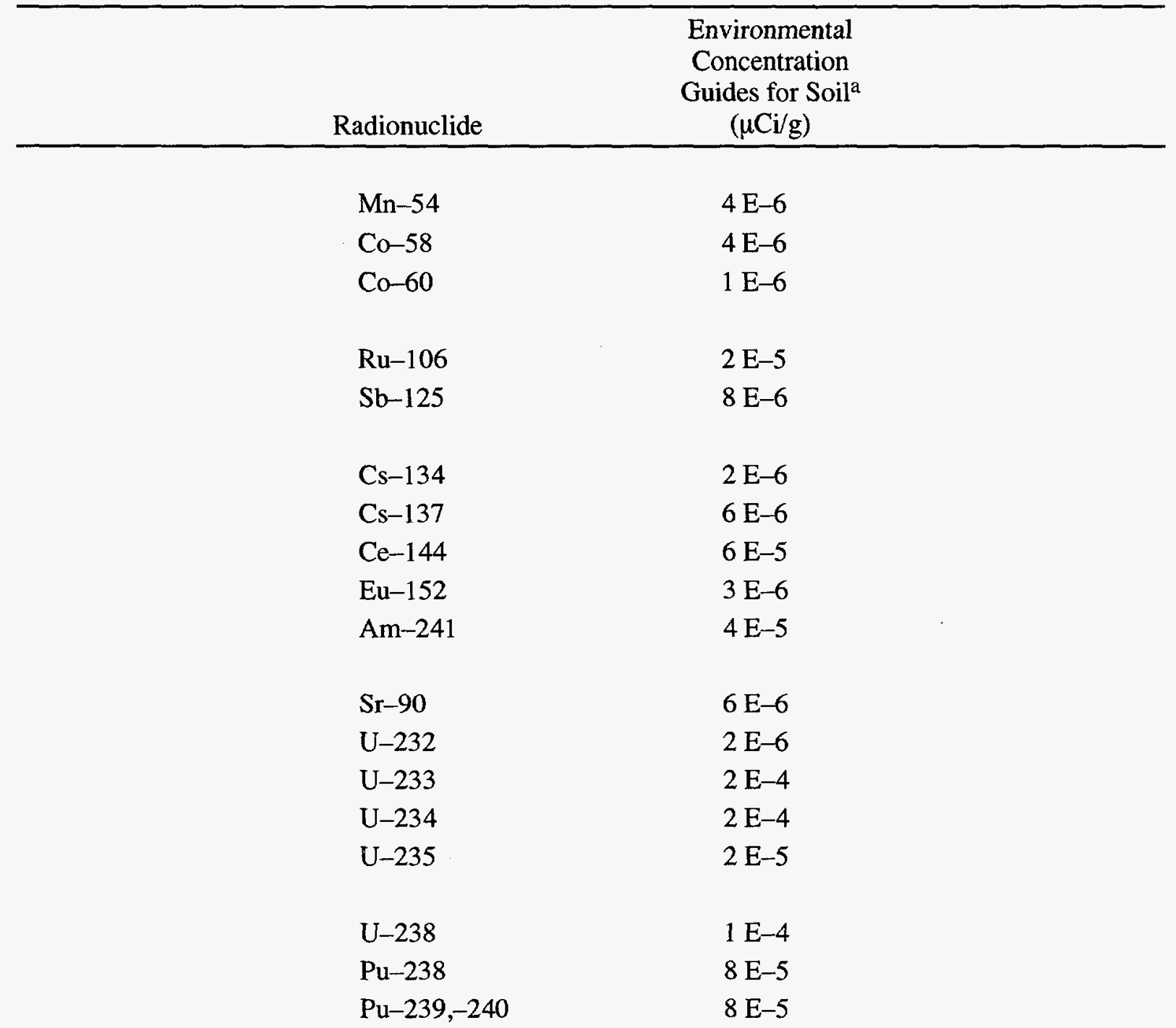

a. See Reference 3. Concentrations correspond to a $50-\mathrm{yr}$ dose commitment of $100 \mathrm{mrem} / \mathrm{yr}$ to a homesteader beginning in the first year after release of facility. This concentration assumes uniform contamination of an area adequate for subsistence farming. 


\section{GROUNDWATER}

The environmental regulations that apply to the drinking water monitoring program are as follows: the Federal Safe Drinking Water Act, Code of Federal Regulations (40 CFR Parts 141-143); the Idaho Regulations for Public Drinking Water Systems, IDAPA 16.01.08000-.08999; ${ }^{3}$ DOE Order 5400.5, Part D; and Environmental Compliance Planning Manual (see Table D-3).

In addition to the eighteen regulated VOCs, unregulated organic compounds are monitored and reported.

The INEL is a nuclear facility, which implies that radiological contamination of the drinking water is a possibility. Because of the possibility of radiological contaminants, Lockheed Martin Idaho monitors for gross alpha/beta and tritium (see Table D-4) as recommended in IDAPA 16.01.08100,06. 
Table D-3. Standards for volatile organic compounds.

\begin{tabular}{|c|c|}
\hline \multicolumn{2}{|c|}{ REGULATED VOCs } \\
\hline Parameter & Maximum Contaminant Level (mg/L) \\
\hline$\overline{\text { Benzene }}$ & 0.005 \\
\hline Vinyl Chloride & 0.002 \\
\hline Carbon Tetrachloride & 0.005 \\
\hline 1,2-Dichloroethane & 0.005 \\
\hline Trichloroethylene & 0.005 \\
\hline 1,1-Dichloroethylene & 0.007 \\
\hline 1,2,4-Trichlorobenzene & 0.07 \\
\hline $1,1,1$-Trichloroethane & 0.200 \\
\hline 1,1,2-Trichloroethane & 0.005 \\
\hline para-Dichlorobenzene & 0.075 \\
\hline cis-1,2-Dichloroethylene & 0.07 \\
\hline 1,2-Dichlorpropane & 0.005 \\
\hline Dichloromethane & 0.005 \\
\hline Ethylbenzene & 0.7 \\
\hline Monochlorobenzene & 0.1 \\
\hline O-Dichlorobenzene & 0.6 \\
\hline Styrene & 0.1 \\
\hline Tetrachloroethylene & 0.005 \\
\hline Toluene & 1.0 \\
\hline $\begin{array}{l}\text { Trans-1,2-Dichloroethy- } \\
\text { lene }\end{array}$ & 0.1 \\
\hline Xylenes (total) & 10.0 \\
\hline \multicolumn{2}{|c|}{ UNREGULATED VOCs WITH NO MCL } \\
\hline Chloroform & O-Chlorotoluene \\
\hline Chlorobenzene & P-Chlorotoluene \\
\hline Bromodichloromethane & Bromobenzene \\
\hline Chlorodibromomethane & 1,3-Dichloropropene \\
\hline Bromoform & $1,2,4$-Trimethylbenzene \\
\hline M-Dichlorobenzene & 1,2,4-Trichlorobenzene \\
\hline 1,1-Dichloropropane & 1,1-Dichloroethane \\
\hline 1,1,1,2-Tetrachloroethane & 1,1,2,2-Tetrachloroethane \\
\hline Chloroethane & 1,3-Dichloropropane \\
\hline 2,2-Dichloropropane & Chloromethane \\
\hline Bromomethane & Isopropylbenzene \\
\hline 1,2,3-Trichlorobenzene & Tert-Butylbenzene \\
\hline N-Butylbenzene & SEC-Butylbenzene \\
\hline N-Propylbenzene & Fluorotrichloromethane \\
\hline Naphthalene & Dichlorodifluoromethane \\
\hline Hexachlorobutadiene & Bromochloromethane \\
\hline 1,3,5-Trimethylbenzene & 1,2,3-Trichloropropane \\
\hline P-I propyltoluene & \\
\hline
\end{tabular}


Table D-4. Applicable radiological drinking water standards.

Parameter

Maximum Contaminant Level $(\mathrm{pCi} / \mathrm{L})$

Gross Alpha 15

Gross Beta 


\section{REFERENCES}

1. Department of Energy, "Radiation Protection of the Public and the Environment," DOE Order 5400.5, February 8, 1990.

2. Idaho Regulations for Public Drinking Water Systems, IDAPA 16.01.08000-.08999, December 5, 1992.

3. EG\&G Idaho, Inc., Development of Criteria for Release of Idaho National Engineering Laboratory Sites Following Decontamination and Decommissioning, EGG-2400, August 1986. 